Chicago-Kent College of Law

Scholarly Commons @ IIT Chicago-Kent College of Law

All Faculty Scholarship

Faculty Scholarship

March 1987

\title{
Law of the Case: A Judicial Puzzle in Consolidated and Transferred Cases and in Multidistrict Litigation
}

Joan E. Steinman

IIT Chicago-Kent College of Law, jsteinma@kentlaw.iit.edu

Follow this and additional works at: https://scholarship.kentlaw.iit.edu/fac_schol

Part of the Civil Procedure Commons

\section{Recommended Citation}

Joan E. Steinman, Law of the Case: A Judicial Puzzle in Consolidated and Transferred Cases and in Multidistrict Litigation, 135 U. Pa. L. Rev. 595 (1987).

Available at: https://scholarship.kentlaw.iit.edu/fac_schol/588

This Article is brought to you for free and open access by the Faculty Scholarship at Scholarly Commons @ IIT Chicago-Kent College of Law. It has been accepted for inclusion in All Faculty Scholarship by an authorized administrator of Scholarly Commons @ IIT Chicago-Kent College of Law. For more information, please contact jwenger@kentlaw.iit.edu, ebarney@kentlaw.iit.edu. 


\title{
LAW OF THE CASE: A JUDICIAL PUZZLE IN CONSOLIDATED AND TRANSFERRED GASES AND IN MULTIDISTRICT LITIGATION
}

\author{
Joan Steinman $\dagger$
}

TABle of Contents

INTRODUCTION . . . . . . . . . . . . . . 596

I. LAW OF THE GASE . . . . . . . . . . . . . . . . . . . . 597

A. A Primer .......................... 597

B. Conflicts among the Circuits ............. 613

II. Complicating Factors ................ 618

A. Change of Judge .................. 618

B. Consolidation ...................... 622

C. Transfer ........................ 626

1. Section 1404 Transfers .............. 627

a. Resolving Choice of Law Issues ....... 628

b. The Effects of Appellate Jurisdictional Limits and of the "Competence" Principle....................

c. Forum Shopping and the Decision to Transfer.................... 648

2. Section 1406 Transfers ............... 651

a. The Nature of the Tranferor Court's Rulings..................... 652

b. The Effects of Appellate Jurisdictional Limits and Choice of Law in Section 1406 Transfers .................

c. Forum Shopping and the Decision to Transfer................... 656

D. Transfer Together with Consolidation ........ 660

III. Section 1407 Litigation ................... 662

† Professor of Law, Illinois Institute of Technology Chicago-Kent College of Law. A.B. 1969, University of Rochester; J.D. 1973, Harvard University. The author thanks Linda Kleszynski, a law student at Illinois Institute of Technology ChicagoKent College of Law, for her unusual dedication in providing research assistance in the preparation of this Article. The author also thanks her colleague Margaret Stewart, for her comments on drafts of this Article, and the Marshall Ewell Research Fund for providing financial support. 
[Vol. 135:595

A. Section 1407 Purposes............... 664

B. Law of the Case in Section 1407 Litigation .... 665

1. Panel Reconsideration .............. 671

2. Transferor Court Rulings in the Section 1407

Transferee Court ................. 672

3. Discovery Courts and Their Rulings ...... 685

4. Transferee Court Rulings ............. 695

5. Reconsideration in the Remand Court..... 700

6. Reconsideration in the Ultimate Transferee

Court ......................... 704

Conclusion $\ldots \ldots \ldots \ldots \ldots \ldots \ldots \ldots \ldots \ldots \ldots \ldots \ldots \ldots$

\section{INTRODUCTION}

The Judicial Panel on Multidistrict Litigation ("JPMDL" or "Panel") has been functioning effectively for almost 20 years. ${ }^{1}$ Indeed, "multidistrict consolidation for pretrial proceedings has become an essential factor in the federal courts' ability to carry their increasing burden of complex litigation."2 Yet the same court that thus acknowledged the benefits of multidistrict consolidation also recognized that such consolidation has sometimes "spawn[ed] procedural dilemmas of its own."s In the last few years two areas of uncertainty have emerged that interfere with the optimal operation of the multidistrict litigation system. First, courts are perplexed as to the application of "law of the case" doctrine in multidistrict litigation, where cases may fall within the jurisdiction of two or three federal district courts consecutively, having landed briefly in the hands of the JPMDL, while still other courts may handle certain discovery issues. ${ }^{4}$ Second, the cases reflect some confusion concerning which federal courts have appellate jurisdiction over

1 The Judicial Panel on Multidistrict Litigation was created on April 29, 1969 by Pub. L. No. 90-296, § 1 (codified at 28 U.S.C. § 1407 (1982 \& Supp. III 1985)).

2 In re Multi-Piece Rim Prods. Liab. Litig. 653 F.2d 671, 680 (D.C. Cir. 1981). In regard to multidistrict litigation generally, see D. HeRR, MULTIDISTRICr LrTIGATION (1986).

${ }^{3}$ Multi-Piece Rim, 653 F.2d at 680.

- For example, under the Federal Rules of Civil Procedure, during a deposition upon oral examination, the court in which the action is pending or the court in the district where the deposition is being taken may order the deposition to cease, or may limit the scope of the deposition or the manner in which it is taken. FED. R. Crv. P. 30(d). Because a person subpoenaed for the taking of a deposition may be required to attend at any place within 100 miles from the place where that person resides, is employed or transacts business in person, or is served, or at another convenient location as set by court order, see FED. R. Crv. P. 45(d)(2), it is quite easy for a court other than the one before which the case is pending to become involved in discovery issues. 
the cases that move among district courts of different circuits. ${ }^{5}$ In light of the substantial and growing number of cases drawn into the multidistrict net, ${ }^{6}$ these unresolved issues will obstruct and delay the administration of justice.

It is the goal of this Article to examine particularly the first of these muddled areas and to suggest how law of the case doctrine should be tailored to fit multidistrict litigation. The necessary starting point is the basic doctrine of law of the case. Part I outlines the contours of the doctrine and details the split among the federal circuits as to how it should be defined and applied. Part II then explains how the content of the doctrine must be adjusted to reflect administrative changes in the handling of cases such as changes of judge, transfer, consolidation, and possible combinations of these three mechanisms. Part II explores, in addition, the threshold question of choice of law that is raised when such administrative changes entail a change of court, and the courts involved define the content of the doctrine differently. All these factors complicate the use of law of the case doctrine in multidistrict litigation. Part III discusses the doctrine in the context of section 1407 litigation, presenting a new synthesis of law of the case to accommodate the peculiarities and fit the needs of multidistrict litigation.

\section{LAW OF THE GASE}

\section{A. A Primer}

In general, law of the case is a concept that precludes the relitiga-

Compare In re Exterior Siding \& Aluminum Coil Litig., 538 F. Supp. 45, 48 (D. Minn. 1982) ("In multidistrict litigation, appeals from the decision of the transferee court [sic] are to be made in the circuit in which the transferee court sits.") and Utah v. American Pipe \& Constr. Co., 316 F. Supp. 837, 839-40 (C.D. Cal. 1970) (appeal from multidistrict litigation lies in transferee's, rather than transferor's, district) with In re Corrugated Container Antitrust Litig., 662 F.2d 875, 879 (D.D.C. 1981) (appeal from a multidistrict litigation transferee judge's order of contempt issued by telephone from the transferee's home district in Texas to a non-party deponent in Washington, D.C. should be heard by the D.C. Court of Appeals, not in the Fifth Circuit, which embraces the transferee district.)

Although the confusion over appellate jurisdiction is not the primary focus of this Article, which court has appellate jurisdiction itself can influence the application of law of the case doctrine.

- From the Panel's creation in 1968 through June 30,1985, a total of 14,489 actions were centralized for pretrial proceedings. See 1985 ANN. REP. DIRECTOR AD. OFF. U.S. CTS. 168 [hereinafter 1985 U.S. Crs. ANN. REP.]. Of those, the Panel acted on 1215 during the twelve month period ended June 30,1985. It had acted on 1120 in the preceding twelve months, see 1984 ANN. REP. DiRECTOR AD. OFF. U.S. CTS. 164, and handled 1060 in the year ending June 30, 1983, see 1983 ANN. REP. Director AD. OFF. U.S. CTS. 158. Thus, in the three most recent years for which statistics are available, the Panel has acted on 23\% of its lifetime caseload. 
tion of issues within the context of a single case once they have been decided. ${ }^{7}$ It is thus akin to the doctrines of collateral estoppel, ${ }^{8}$ res judi-

7 See Messinger v. Andersen, 225 U.S. 436, 444 (1912); Gindes v. United States, 740 F.2d 947, 949 (Fed. Cir. 1984) (quoting U.S. v. Turtle Mountain Band of Chippewa Indians, 612 F.2d 517, 520 (Cl. Ct. 1979)), cert. denied, 105 S. Ct. 569 (1984); Loumar, Inc. v. Smith, 698 F.2d 759, 762 (5th Cir. 1983); Hayman Cash Register Co. v. Sarokin, 669 F.2d 162, 165 (3d Cir. 1982); 1B J. MOore, J. LuCAS \& T. CurRIER, MOORE's FEDERAL PRACTICE, II 0.404 [1], at 117 (2d ed. 1984) [hereinafter MoORE's Federal Practice]; 18 G. Wright, A. Miller \& E. Cooper, Federal Practice AND PRocedure, § 4478, at 788 (1981) [hereinafter Wright \& Miller]; A. Vestal, Law of the Case: Single-Suit Preclusion, 12 UTAH L. Rev. 1, 1-4 (1967).

${ }^{8}$ See 1B Moore's Federal Practice, supra note 7, II 0.404 [1], at 117-18. Collateral estoppel, generally speaking, precludes a person who was a party, or in privity with a party, in previous litigation from relitigating issues actually litigated and decided in the prior action and necessary to the prior judgment. See, e.g., Friedenthal, Kane \& Miller, Civil Procedure, $\S \S 14.2$, 14.9-14.11, at 658-76 (1985) (defining and stating the requirements for application of collateral estoppel) [hereinafter FRIEDENTHAL]. It is similar to law of the case doctrine in applying only to issues already litigated and decided. In addition, both doctrines may apply without the case in which issues have been decided having reached final judgment. For example, interlocutory orders may be given collateral estoppel effect. Id. § 14.9, at 659. Law of the case doctrine applies, however, when issues once decided in a case recur or are raised for reconsideration in the later stages of the same case, whereas collateral estoppel prevents litigation of the same issues in successive suits. This difference has made it inappropriate for law of the case doctrine to entail the "necessary to the judgment" requirement. In addition, because law of the case issues arise within a single litigation, the doctrine does not pose the risk of trapping unwary litigants who may not have foreseen the ramifications for other lawsuits of issue determinations made in a prior action. Nevertheless, issue determinations theoretically could have unforeseen, if not unforeseeable, consequences within a single lawsuit as well if, for example, determinations made for the purpose of deciding jurisdictional issues are also relevant to the merits. Finally, collateral estoppel applies only when the burdens of proof are the same in the two actions. One could not, for example, collaterally estop a defendant from relitigating issues decided against her by a preponderance of the evidence in a civil case when they arise again in a criminal prosecution, where the matters in issue must be proved beyond a reasonable doubt. By contrast, when law of the case issues arise in a series of federal district courts hearing a single civil action, the burden of proof rarely will change. The only imaginable circumstance in which such a change might occur would be transfer during trial in a diversity suit, where each federal court would apply a different state's law on burden of proof. A change in the bundle of applicable legal principles can occur by virtue of an intercircuit transfer. See infra notes 184 and 202 and accompanying text. In that circumstance, the "issue" will have changed. Similarly, federal appellate courts may confront the same issues in a single case but presented under different circumstances, for instance, in a petition for writ of mandamus and upon ordinary appeal after final judgment. The courts then need to consider whether the change in governing review standards alters the issue presented so that law of the case doctrine ought not to apply. See Skil Corp. v. Millers Falls Co., 541 F.2d 554, 563 (6th Cir.) (Adams, J., dissenting) (stating that the same question presented in a different context constitutes a different legal issue because the determination is controlled by a different legal standard), cert. denied, 429 U.S. 1029 (1976).

Also related to law of the case doctrine is "direct estoppel," by which issues actually litigated and necessarily determined in support of a judgment that is not "on the merits" are binding in subsequent suits on the same cause of action. In light of the foregoing discussion, the similarities and differences between the two doctrines should be reasonably self-evident. 
cata, ${ }^{9}$ and stare decisis. ${ }^{10}$ If law of the case were strictly applied, a trial court would be absolutely bound by its first adjudication of an issue; there would be no possibility of a change of decision at the trial level. ${ }^{11}$ The doctrine rarely has been considered so ironclad, however, given the federal trial courts' unquestioned power to reconsider their earlier rulings. Law of the case principles are therefore best understood as rules of sensible and sound practice that permit logical progression toward judgment, but that do not disable a court from altering prior interlocutory decisions in a case. ${ }^{12}$ Indeed, the courts have created a variety of

- Res judicata, or claim preclusion as it is often called today, differs from law of the case as does collateral estoppel and in additional respects. It applies only when there is a final judgment on the merits, and precludes subsequent suits on the same cause of action, preventing relitigation not only of every ground of recovery, or defense, that was actually litigated, but also of every ground or defense that might have been presented. See, e.g., FRIEDENTHAL, supra note 8, §§ 14.3, 14.6-14.7, at 641-55 (discussing the requirements for application of res judicata). This Article argues that, just as res judicata and collateral estoppel apply only when the judgment-rendering court had subject matter jurisdiction over a case and personal jurisdiction over the parties, and hence rendered "valid" rulings and judgments, law of the case doctrine, too, should apply only in those circumstances. See infra notes 192 and 198 and accompanying text.

${ }_{10}$ See Loumar, Inc. v. Smith, 698 F.2d 759, 762 (5th Cir. 1983) (rationale of law of the case and stare decisis is the same: court will follow a prior ruling unless it was erroneous, is no longer sound, or would work an injustice). The term "stare decisis" derives from the Latin phrase "stare decisis et non quieta movere," meaning "to adhere to precedents and not to unsettle things which are established." Bonner v. City of Pritchard, 661 F.2d 1206, 1211 (11th Cir. 1981). Stare decisis describes the effect of previous judicial decisions on present litigation, prescribing that like cases should be decided alike by courts of a single jurisdiction. Stare decisis applies only to questions of law, perpetuating the general principles by which particular cases have been decided, and it applies to all litigants, whether or not they had any connection with the precedent-setting case. It is, however, less strict than the doctrines of res judicata and collateral estoppel; precedents may be overruled. See FrIEDENTHAL, supra note $8, \S 14.1$, at 610.

Stare decisis is grounded in a combination of considerations:

the desirability that the law furnish a clear guide for the conduct of individuals, to enable them to plan their affairs with assurance against untoward surprise [and to encourage the settlement of disputes]; the importance of furthering fair and expeditious adjudication by eliminating the need to relitigate every relevant proposition in every case; and the necessity of maintaining public faith in the judiciary as a source of impersonal and reasoned judgments.

Moragne v. States Marine Lines, Inc., 398 U.S. 375, 403 (1970) (overruling The Harrisburg, 119 U.S. 199 (1886)); see also, Bonner v. City of Pritchard, 661 F.2d at 1209 (holding that the decisions of the Fifth Circuit through Sept. 30,1981, would be binding as precedent in the new Eleventh Circuit because stability and predictability are essential factors in the proper operation of the rule of law).

12 See Vestal, supra note 7 , at 15.

12 See Arizona v. California, 460 U.S. 605, 618 (1983) ("[L]aw of the case is an amorphous concept. As most commonly defined, the doctrine posits that when a court decides upon a rule of law, that decision should continue to govern the same issues in subsequent stages in the same case. . . . Law of the case directs a court's discretion, it does not limit the tribunal's power."); Messinger v. Anderson, 225 U.S. 436, 444 
exceptions, and commentators have discerned and advocated additional variables which should temper the rigor with which the doctrine is applied. Thus, many decisions indicate that a ruling should be reconsidered when controlling law has been changed by an intervening decision of a higher court, ${ }^{13}$ when relevant evidence is newly available, ${ }^{14}$ and when necessary to correct a clear error and to prevent manifest injustice. ${ }^{15}$

Courts and commentators have recognized that the nature or quality of the ruling in question and the stage of the proceedings are also pertinent variables. Rule 54(b) of the Federal Rules of Civil Procedure provides that all decisions are "subject to revision at any time before the entry of judgment adjudicating all the claims and the rights and liabilities of all the parties."16 It has been suggested that courts should more liberally reconsider early pretrial rulings than late prejudgment decisions. ${ }^{17}$ In addition, avowedly preliminary or tentative rulings should not trigger law of the case consequences. ${ }^{18}$ Even as to determinations

(1912) (law of the case is a matter of practice, not a limit upon power); Remington v. Central Pac. R.R., 198 U.S. 95, 100 (1905) (same); Hill v. BASF Wyandotte Corp., 696 F.2d 287, 290 n.3 (4th Cir. 1982) (same); 1B Moore's Federal Practice, supra note 7, I 0.404 [1], at 119-20; 18 WRIGHT \& MiLlER, supra note 7, § 4478, at 789-90.

13 See Crane Co. v. American Standard, Inc., 603 F.2d 244, 249 (2d Cir. 1979) (law of case did not preclude reconsideration of whether plaintiff had a cause of action when reexamination made good sense in light of intervening Supreme Court decision); Smith v. Nixon, 582 F.Supp. 709, 711 n.2 (D.D.C. 1984) (law of the case did not preclude application of intervening Supreme Court decisions as to defendants' official immunity); 1B MoORE's Federal PRACTICE, supra note 7, II 0.404 [1], at 121-23; Vestal, supra note 7, at 16.

14 See Peterson v. Lindner, 765 F.2d 698, 704 (7th Cir. 1985) (where new evidence came to light after first ruling, successor judge had power to reconsider); Doe v. New York City Dep't of Social Servs., 709 F.2d 782, 789 (2d Cir.) (in discussing whether to depart from law of the case made on prior appeal, court rejected a claim of new evidence), cert. denied, 464 U.S. 864 (1983); Hayman Cash Register Co. v. Sarokin, 669 F.2d 162, 169 (3d Cir. 1982) (if new evidence is available to the second judge, an exception to law of the case exists because the question really has not been decided earlier).

${ }_{15}$ See Arizona v. California, 460 U.S. at 618 n.8 (dictum); 18 WRIGHT \& MilleR, supra note $7, \S 4478$, at 790-91 \& n.5.

Cases often cite the triad of change in law, new relevant evidence, and correction of error as the "exceptional circumstances" under which a departure from a prior ruling is warranted. See, e.g., Gindes v. United States, 740 F.2d 947, 950 (Fed. Cir.), cert. denied, 105 S. Ct. 569 (1984); Laffey v. Northwest Airlines, Inc., 740 F.2d 1071, 1102-03 (D.C. Cir. 1984), cert. denied, 469 U.S. 1181 (1985); Dynalectron Corp. v. United States, 4 Ct. Cl. 424, 431 (1984), aff'd mem., 758 F.2d 665 (Fed. Cir. 1984); White v. Murther, 377 F.2d 428, 431-32 (5th Cir. 1967).

${ }^{16}$ FED. R. Civ. P. 54(b).

1718 WRIGHT \& MILLER, supra note $7, \S 4478$, at 791-92.

$18 \mathrm{See}$ Board of Trade v. Commodity Futures Trading Comm'n, 605 F.2d 1016, 1020 (7th Cir. 1979) (denial of emergency motion for stay pending appeal was not law of the case with respect to the merits of the appeal), cert. denied, 446 U.S. 928 (1980); 
intended to put a matter to rest, distinctions have been proposed on the ground that some issues, most notably questions of fact and matters of discretion, are particularly unsuited for reconsideration, whereas issues "of intrinsic importance or [having an] impact on nonparties"19 are especially suitable for reconsideration. The latter category includes such matters as federal court subject matter and personal jurisdiction, appellate jurisdiction, the existence of indispensable parties, and constitutional issues generally. ${ }^{20}$

Berrigan v. Sigler, 499 F.2d 514, 518 (D.C. Cir. 1974) (decision on whether to grant preliminary injunction is not law of the case for purposes of further proceedings); United States v. Klein, 474 F. Supp. 1243, 1246 (S.D.N.Y. 1979) (law of the case would not be applied in criminal prosecution where parties understood that rulings of different judge in prior trial would not be considered binding and defendant had renewed many applications upon which prior judge had ruled), affd mem., 614 F.2d 1292 (2d Cir. 1979), cert. denied, 447 U.S. 905 (1980); 18 WRIGHT \& MILLER, supra note 7, § 4478, at 798 \& n.31. The Wright \& Miller treatise states, "[R]ulings that simply deny extraordinary relief for want of a clear and strong showing on the merits . . . do not trigger law of the case consequences." Id. If a party renewed his motion for extraordinary relief, however, it is likely that the earlier ruling would be given law of the case consequences. The treatise writers probably envisioned questions raised by the motion for extraordinary relief arising in a procedural posture where the legal standard would be different. The earlier ruling consequently would not be on the precise issue later raised.

1018 WRIGHT \& MiLlER, supra note $7, \S 4478$, at 799.

20 See, e.g., Loumar, Inc. v. Smith, 698 F.2d 759, $762-63$ (5th Cir. 1983) (law of the case did not preclude successor judge from granting motion to dismiss for lack of personal jurisdiction that was denied by predecessor judge; if facts showed a lack of jurisdiction, it would have been sheer waste to permit a trial and await reversal); Association of Inv. Brokers v. SEC, 676 F.2d 857, 863 (D.C. Cir. 1982) (law of the case did not preclude merits panel from reconsidering petitioners' standing, particularly when motions panel of the court had ruled in unelaborated order); Green v. Department of Commerce, 618 F.2d 836, 839 n.9 (D.G. Cir. 1980) (law of the case does not apply to fundamental question of subject matter jurisdiction; appellate court had to dismiss for lack of appellate jurisdiction because district court's order was not a final judgment); Crane Co. v. American Standard, Inc., 603 F.2d 244, 248-49 (2d Cir. 1979) (law of the case did not preclude reconsideration of whether plaintiff had standing and a cause of action; ruling against plaintiff conserved judicial resources by eliminating need for proceedings on the merits, and "unseemliness" of an appearance of inconsistency was outweighed by clear and correct delineation of who may sue); Potomac Passengers Ass'n v. Chesapeake \& O. Ry., 520 F.2d 91, 95 n.22 (D.C. Cir. 1975) (law of the case did not foreclose, on second appeal, reconsideration of federal subject matter jurisdiction); Rogers v. Valentine, 426 F.2d 1361, 1363 n.2 (2d Cir. 1970) (law of the case did not preclude trial judge from exercising his discretion to decide, after trial, that court should not exercise pendent jurisdiction over a state law claim, despite contrary decision by a predecessor judge); Vestal, supra note 7, at 26-29 (discussing situations where law of the case should not apply).

Professor Vestal also categorizes as poorly suited for reconsideration "judgments" concerning the sufficiency of the evidence to go to the jury, and what he calls attempts to get to the merits of the controversy. See id. at 27-28. Neither of these suggestions will be evaluated here because, as they are elaborated by Professor Vestal, neither is a law of the case issue that arises between coordinate trial level courts, and neither seems to be an issue that would be influenced by a prior involvement in multidistrict mechanisms. 
Law of the case is not a single strand doctrine, but rather a multifaceted one. Writing in 1967, Professor Allan Vestal identified four distinct situations in which a ruling or decision has been made in a case and the same legal problem arises a second time in the same case:

(1) An appellate court may rule on a matter and then the same legal question may be raised in the trial court after the case has been remanded to that court for further proceedings. (2) An appellate court may rule on a matter and then the same legal question may be raised in the same appellate court when the case is appealed a second time.

(3) A trial court may rule on a matter and then the same legal question may be raised a second time in the same trial court. This may be before the same judge or before a different judge.

(4) It may be urged that an adjudication by a trial court, under some circumstances, may be the "law of the case" so that the matter cannot be reconsidered by an appellate court on review. This seems to be an anomaly . . . 21

This Article focuses on the third of Vestal's "situations," as it is the one most often affected by multidistrict procedures. In particular, the Article will examine the special effects of consolidation, transfer, and multidistrict litigation on Vestal's third prong of law of the case doctrine. Judicial and scholarly discussion has identified several policy justifications for this aspect of law of the case doctrine. First, once a trial court has decided a legal issue in a case, it is inefficient for the same court or another court at the same level to reconsider that issue. As Professor Moore has written, the doctrine is "a management practice to permit logical progression toward judgment. . . [E]fficient disposition of the case demands that each stage of the litigation build on the last, and not afford an opportunity to reargue every previous ruling." ${ }^{22} \mathrm{He}$ continues,

[T] he very purpose of deciding some issues ahead of others is to aid in the logical and orderly disposition of the whole. It would be utterly destructive of this end if each successive de-

21 Vestal, supra note 7 , at 4 . Vestal adds to this list the observation that certain law of the case problems that arise in federal court are unusual because of federal-state interplay or because of "aberrational" provisions of the United States Code, citing transfer of a case under 28 U.S.C. $\$ 1404$. Id. at 5 . It should be noted, however, that Professor Vestal wrote two years before the JPMDL's creation, so that he did not consider the special effects on law of the case doctrine of multidistrict litigation as structured by 28 U.S.C. $\S 1407$.

${ }^{22}$ 1B MOORE's Federal Practice, supra note 7, I 0.404 [1], at 118. 
cision resulted in the reconsideration of every previous one . . [T] practice that protects the ability of the court to build to its final judgment by cumulative rulings, with reconsideration or review postponed until after the judgment is entered. ${ }^{23}$

Thus, law of the case doctrine narrows the issues as a case progresses and moves it along toward final judgment. ${ }^{24}$

Second, and closely related to the efficiency and progress concerns described above, law of the case doctrine also serves efficiency in that it saves both litigants and the courts from duplications of effort. If permitted to argue and brief the same issue repeatedly during the course of the same litigation, some litigants would be indefatigable in their efforts to persuade or to wear down a given judge in order to procure a favorable ruling. ${ }^{25}$ Such use of clients' finances, legal counsels' time and energy, and judicial resources is wasteful from a systemic perspective. Even greater waste would ensue from representation of a decided issue to a different judge who had come to preside over a case. Moreover, absent law of the case doctrine, litigants would have an incentive to "shop" rulings from one judge to another, ${ }^{26}$ if local court rules permitted such reargument. Such shopping would undermine both aspects of efficiency served by law of the case doctrine.

Third, use of law of the case principles furthers the goal of consis-

23 Id. If 0.404 [4.-1], at 124-26.

24 See, e.g., White v. Higgins, 116 F.2d 312, 317 (1st Cir. 1940) (stating that law of the case narrows the issues in successive stages of litigation).

${ }^{25} 18$ WRIGHT \& MILLER, supra note $7, \S 4478$, at 789-90. When the arguments were fully canvassed and evaluated before and no new insight or illumination has been tendered, courts are particularly unlikely to afford reconsideration. See, e.g., Kuenz v. Goodyear Tire \& Rubber Co., 617 F. Supp. 11, 14 (N.D. Ohio 1985) (when issues have been carefully considered and decisions rendered, the only reason commending reconsideration is a change in the factual or legal underpinnings of the decision); Gantt v. Boone, Wellford, Clark, Langschmidt \& Pemberton, 559 F. Supp. 1219, 1225 (M.D. La. 1983) (subject matter jurisdiction would not be considered a fourth time when counsel produced no different law or facts), aff'd mem., 742 F.2d 1451 (5th Cir. 1984).

${ }^{26}$ See Roberts v. Cooper, 61 U.S. (20 How.) 467, 481 (1857) ("[T]here would be no end to a suit if every obstinate litigant could, by repeated appeals, compel a court to listen to criticisms on their opinions, or speculate of chances from changes of its members"); Gindes v. United States, 740 F.2d 947, 949 (Fed. Cir. 1985) (no litigant deserves an opportunity to go over the same ground twice, hoping that the passage of time or changes in the composition of the court will provide a more favorable result), cert. denied, 105 S. Ct. 569 (1984); Grane Co. v. American Standard, Inc., 603 F.2d 244, 248 (2d Cir. 1979) (quoting Zdgnok v. Glidden Co., 327 F.2d 944, 953 (2d Cir.), cert. den., 377 U.S. 934 (1964)) (law of the case eliminates the potential unseemliness of a court altering a legal ruling as to the same litigants with the danger that this may reflect only a change in the membership of the tribunal); 18 WRIGHT \& MILLER, supra note $7, \S 4478$, at 794 . 
tency in judicial decisions. Adherence to a decision, with or without reconsideration of its merits, promotes consistency. Reconsideration introduces the opportunity for a change of mind or a difference of opinion; an inconsistent decision may emerge. Consistency itself is valued for several reasons. Lawyers and courts generally "hold" that the governed are justified in basing their conduct on the law as it is declared and interpreted by courts. ${ }^{27}$ Inconsistency in judicial decisions makes it very difficult for individuals to use common law as a guide in their activities, and can lead to the disappointment of justified expectations. In addition, inconsistency and vacillation in decisions undermine public confidence in the judiciary as a whole, thus lessening respect for and obedience to the law. ${ }^{28}$ Consistency in decision, therefore, is valued for its respect-building effects as well. Many courts and commentators also believe that when an issue is presented to a judge other than the one who initially ruled, a differing decision reflects disrespect for the initial judgment and for the first judge, to the detriment of both that judge and the judiciary generally, again through a decline in public respect and

27 See, e.g., Liddell v. Missouri, 731 F.2d 1294, 1305 (8th Cir.) ("We are loath to retract our previous declarations on settled issues when a case returns on appeal; to do so ignores important considerations of judicial economy and ignores our interest in protecting the settled expectations of parties who have conformed their conduct to our guidelines."), cert. denied, 105 S. Ct. 82 (1984); Dictograph Products Co. v. Sonotone Corp., 230 F.2d 131, 135 (2d Cir.) ("[T]here is no imperative duty to follow the earlier ruling-only the desirability that suitors shall, so far as possible, have reliable guidance how to conduct their affairs."), cert. dismissed, 352 U.S. 883 (1956); RESTATEMENT (SECOND) OF JUDGMENTS, \$74 comment $\mathrm{f}$ (1980) ("But beyond resolving legal disputes over events of the past, a judgment also creates relationships for the future. . . . In proportion as the plans and acts in reliance on the judgment are substantial in moment and prolonged in duration, they become considerations that ought to give stability to the judgment."); $c f$. Arizona v. California, 460 U.S. 605, 626 (1983) ("Detrimental reliance is certainly relevant in a balancing of the equities when determining whether changed circumstances justify modification of a decree.").

${ }^{28}$ Vestal, supra note 7, at 1 ("public confidence must be preserved in the judicial system by adhering to a decision once made"); Brunet, A Study in the Allocation of Scarce Judicial Resources: The Efficiency of Federal Intervention Criteria, 12 GA. L. REv. 701, 719 (1978):

Inconsistent findings of fact are inefficient for numerous familiar reasons. They fail to perform the conflict-avoidance or lawmaking functions of dispute resolution that represent the very rationale for a civil litigation system and produce the harmful negative externalities associated with undecided conflict. Lack of confidence in the judicial system damages society and represents another negative externality. Inconsistent determinations of matters of fact and law tend to degrade the public's confidence in the judiciary and government, confidence which is essential to popular acceptance of court decisions and the behavioral concepts (e.g., deterrence of harmful conduct and adherence to law) central to the judiciary's effectiveness in making a rule system effective. Inconsistency harms members of society because if society ignores the deterrence goal of the decision, it frustrates the allocative purpose of the norm. 
confidence. ${ }^{29}$ Because of the multiple harms believed to flow from inconsistent decisions, law of the case doctrine is valued for its tendency to preclude inconsistency.

Despite these policy undergirdings, as previously noted, ${ }^{30}$ law of the case is not ironclad in precluding reconsideration of judges' rulings. The primary value contending against absolute preclusion is that of the trial court deciding correctly and wisely, thereby better serving the ends of justice, without either distorting the law or treating litigants unfairly. ${ }^{31}$ The efficiency gained through avoidance of appellate reversals and retrials is a valued by-product of correct trial court rulings. When reconsideration is particularly likely to correct an erroneous ruling or to lead to a manifestly more just decision, the policies supporting law of the case preclusion are outweighed, and generally recognized exceptions to the doctrine are born..$^{32}$ Although reconsideration to correct a clear error and to prevent manifest injustice flows directly from these policies, mere doubt as to the correctness of a prior ruling typically will not suffice to elicit reconsideration. ${ }^{33}$ When there is "mere doubt," as op-

29 See, e.g., Hardy v. North Butte Mining Co., 22 F.2d 62, 63 (9th Cir. 1927) (quoting Appleton v. Smith, 1 Fed. Cas. 1075, no. 458) ("It would be in the highest degree indelicate for one judge of the same court thus to review and set aside the action of his associate in his absence.."); In re Plantation Manor Restaurant, 45 Bankr. 229, 231 (Bankr. E.D. \& W.D. Ark. 1984) ("the reversal of one coordinate judge by another can only stultify the law and cheapen the judicial process").

so See supra notes $12-15$ and accompanying text.

s1 See, e.g., Peterson v. Lindner, 765 F.2d 698, 704 (7th Cir. 1985) (law of the case must yield to rational decisionmaking); Gallimore v. Missouri Pac. R.R., 635 F.2d 1165,1172 (5th Cir. 1981) (law of the case should give way to interests of justice and economy); Crane v. American Standard, Inc., 603 F.2d 244, 248 (2d Cir. 1979) (the unseemliness of an appearance of inconsistency may be outweighed by the benefit of correct delineation of who may sue); United States v. Koenig, 290 F.2d 166, 172 (5th Cir. 1961) (the matter is within the sound discretion of the trial judge conducting her court in the interest of furthering justice), affd, 369 U.S. 121 (1962); Vestal, supra note 7, at 31 (" 'Law of the case' should be considered in light of the ultimate goals of the judicial process ....").

${ }_{32}$ See, e.g., Peterson v. Lindner, 765 F.2d at 704 (a trial judge should not risk reversal because of the erroneous ruling of another judge any more than because of an erroneous ruling of her own); Robinson v. Parrish, 720 F.2d 1548, 1550 n.* (11th Cir. 1983) (by correctly granting a motion for summary judgment that had been denied by a predecessor judge, the successor judge saved the time and effort of trial); Loumar, Inc. v. Smith, 698 F.2d 759, 763 (5th Cir. 1983) (if the facts presented to the judge truly showed a lack of jurisdiction, it would have been sheer waste for him to permit a trial and await reversal by the court); Hill v. BASF Wyandotte Corp., 696 F.2d 287, 290 n.3 (4th Cir. 1982) (stating that court should not, in review, affirm a legally erroneous ruling because it was "compelled" by law of the case); American Standard, 603 F.2d at 248 (where a U.S. Supreme Court decision demonstrates that a ruling on which a judgment would depend is in error, no principle of law of the case warrants a failure to correct the ruling).

ss See, e.g., Fogel v. Chestnutt, 668 F.2d 100, 109 (2d Cir. 1981) ("It is not enough . . . that defendants could now make a more persuasive argument . . . . The law of the case will be disregarded only when the court has 'a clear conviction of error' 
posed to a clear conviction that a previous ruling was erroneous, there is no sufficient guarantee that the trial court's second decision will be more correct, more just, or more likely to stand up on appeal, to justify the various costs of reconsideration. ${ }^{34}$

The exception for situations in which there has been an intervening change of controlling law also can be viewed as flowing from the policies favoring correction of error and avoidance of reversals. The exception also represents, however, a departure from pure law of the case problems, i.e., situations in which mere reconsideration of the same issue is sought. Unlike situation in which a trial court simply has changed its mind about the proper ruling on a given set of facts, in these cases the trial court really is faced with a different mix of law and fact than it ruled upon earlier, because an appellate court whose decisions are binding upon it has since spoken on the pertinent legal principles. ${ }^{35}$ Vertical control must prevail over horizontal consistency or reversal is likely to follow. Reconsideration, if not a change of decision, is appropriate and perhaps required in light of changes in allegedly controlling law, common or statutory. ${ }^{38}$

with respect to a point of law on which its previous decision was predicated."), cert. denied, 459 U.S. 828 (1982); Northern Helex Co. v. United States, 634 F.2d 557, 562 (Ct. Cl. 1980) (mere suspicion of error does not warrant reopening a point; only certainty of error suffices); Zdanok v. Glidden Co., 327 F.2d 944, 952-53 (2d Cir.) (court adhered to a ruling by a divided panel despite a contrary ruling by a different court of appeals, saying, "[A] clear conviction of error on a point of law that is certain to recur . . . will prevail over 'the law of the case' whereas 'mere doubt' will not."), cert. denied, 377 U.S. 934 (1964); White v. Higgins, 116 F.2d 312, 317 (1st Cir. 1940) (stating that mere doubt is not enough to open a point for reconsideration).

Beyond the desire to do justice to the parties before the court, the stare decisis effects of a decision provide an additional reason to correct a clear error so as not to perpetuate it. This is true a fortiori for decisions made at an appellate level.

34 The process of deciding whether a prior ruling is or is not clearly erroneous or manifestly unjust itself entails some reconsideration of the issue. Hence, the policies against reconsideration are inevitably breached to a degree even when a court ultimately decides to invoke law of the case doctrine.

35 Each federal district court falls under the jurisdiction of one of the federal appellate judicial circuits. See 28 U.S.C. § 1294 (1982 \& Supp. 1985). Under both stare decisis and law of the case, the lower courts subject to the jurisdiction of a court of appeals must adhere to the unreversed dictates of that appellate tribunal. See, e.g., Beverly Enterprises v. NLRB, 727 F.2d 591, 593 (6th Cir. 1984).

36 See Amen v. City of Dearborn, 718 F.2d 789, 793-94 (6th Cir. 1983) (law of the case had to yield to elimination of amount in controversy requirement for federal question jurisdiction under 28 U.S.C. \$ 1331), cert. denied, 465 U.S. 1101 (1984); Crane Co. v. American Standard, Inc., 603 F.2d 244, 248-49 (2d Cir. 1979) (law of the case that plaintiff had standing should yield in light of intervening Supreme Court ruling.); Zichy v. Gity of Philadelphia, 590 F.2d 503, 508 (3d Cir. 1979) ("This court has a duty to apply a supervening rule of law despite its prior decisions to the contrary when the new legal rule is valid and applicable to the issues of the case."); Pettway v. American Cast Iron Pipe Co., 576 F.2d 1157, 1196 (5th Cir. 1978) (perhaps the most cogent reason possible for not following a previous decision in the same litigation is an 
The exception to law of the case doctrine that is applicable when relevant evidence is newly available similarly presents a different mix of law and fact than was ruled upon earlier. Mere reconsideration is not involved. Either the facts existed on both occasions, but only came to counsels' and to the court's attention after the first ruling, or some relevant facts actually have changed. In either situation, the new factual base for a court's decision may differ so substantially from the previous one that reconsideration is appropriate in order to allow a manifestly more just decision or to obviate an avoidable reversal. ${ }^{37}$

Other variables that courts and commentators have deemed relevant to the decision whether to reconsider reflect not only the policies favoring correct decisions and avoidance of reversals, but also other policy considerations. For example, the notion that courts should more liberally reconsider early pretrial rulings than decisions in a case's later stages appears to be based on the recognition that mistakes made early in the course of the litigation can taint and infect all further proceedings. ${ }^{38}$ The trial court's prompt correction of its own mistakes more quickly gets a case back on the right track and minimizes the harm

intervening decision by the Supreme Court which casts doubt on the validity of the original decision), cert. denied, 439 U.S. 1115 (1979).

An intervening decision of state law by a state court may require a federal court to reconsider and revise its earlier view, and thereby depart from law of the case. See Delano v. Kitch, 663 F.2d 990, 996 (10th Cir. 1981), cert. denied, 456 U.S. 946 (1982). But of. Handi Inv. Co. v. Mobil Oil Corp., 653 F.2d 391, 392-93 (9th Gir. 1981) (state supreme court decision did not contradict court of appeals' interpretation of state law; thus, on remand, trial court was not justified in departing therefrom).

In the context of collateral estoppel, too, courts and commentators recognize that an intervening change in the relevant legal climate may warrant reexamination of the rule of law applicable as between the parties, particularly where preclusion would result in a manifestly inequitable administration of the laws. See Restatement (SECOND) OF JUDGMENTS $\S 28$ comment c (1980). As the Restatement Reporters note,

[T]wo concepts of equality are in competition with each other. One is the concept that the outcomes of similar legal disputes between the same parties at different points in time should not be disparate. The other is that the outcomes of similar legal disputes being contemporaneously determined between different parties should be resolved according to the same legal standards.

Id.

37 See, e.g., Zenith Laboratories, Inc. v. Carter-Wallace, Inc., 530 F.2d 508, 512 ( $3 \mathrm{~d}$ Cir.) (a district court is obliged to take cognizance of a changed factual situation and may alter an earlier order accordingly), cert. denied, 429 U.S. 828 (1976); Interpace Corp. v. Philadelphia, 438 F.2d 401 (3d Cir. 1971) (same); Rogers v. Valentine, 306 F. Supp. 34, 41 (S.D.N.Y. 1969) (because the first judge, at the time of his decision, did not have the benefit of later developments in this case, a redetermination of the application of pendent jurisdiction was appropriate), affd, $426 \mathrm{~F} .2 \mathrm{~d} 1361$ (2d Cir. 1970); $c f$. Baumer v. United States, 685 F.2d 1318, 1321 (11th Cir. 1982) (departure from law of the case was not warranted when the plaintiffs intentionally had chosen not to use the "new evidence" at trial).

3818 WRIGHT \& MilleR, supra note 7, § 4478, at 791-92. 
done by any early errors. The idea that preliminary or tentative rulings should not trigger law of the case consequences reflects an expectation that either the court's knowledge of the relevant facts or the relevant facts themselves will change, thus making it inappropriate or unwise to regard the matter as settled. ${ }^{38}$

In general, the view that certain matters are peculiarly suitable for reconsideration is grounded upon the importance of having them decided correctly. The matters typically falling in this category include the court's jurisdiction over a case and the indispensability of parties who cannot be joined. ${ }^{40}$ In these instances and in some others, ${ }^{41}$ a civil action should cease immediately if the requirements at issue are not met. A court that lacks subject matter jurisdiction lacks constitutional or statutory authority to hear the case. If, at any point in the trial court or on appeal, the court is held to lack subject matter jurisdiction, ${ }^{42}$ all of its orders will be nullified and the parties' efforts will have gone for naught. Similarly, in the case of indispensable parties, a civil action must cease when the court has determined in equity and good conscience that the action should not proceed among the parties before it. ${ }^{43}$ In both instances a trial court should reconsider its decision and determine whether it lacks subject matter jurisdiction or whether a party who cannot be joined is indispensable, rather than refuse to rethink its first ruling by invoking law of the case and proceed through an adjudication that may be thrown out on appeal. ${ }^{44}$

so There is an obvious tie here to the exception for new evidence. See supra note 37 and accompanying text. It may be that the relatively liberal attitude toward reconsideration of early pretrial rulings also partakes of an implicit assumption that the foundation of such rulings may be incomplete or may change.

40 "If a person as described in subdivision (a) (1)-(2) . . . cannot be made a party, the court shall determine whether in equity and good conscience the action should proceed among the parties before it, or should be dismissed, the absent person being thus regarded as indispensable." See FED. R. Civ. P. 19(b).

41 See supra note 20 and accompanying text.

42 "Whenever it appears by suggestion of the parties or otherwise that the court lacks jurisdiction of the subject matter, the court shall dismiss the action." FED. R. Grv. P. 12(h)(3). However, collateral attacks on judgments for lack of subject matter jurisdiction in the judgment rendering court often fail. See, e.g., Durfee v. Duke, 375 U.S. 106,111 (1963) ("a judgment is entitled to full faith and credit even as to questions of jurisdiction when ... these questions have been fully and fairly litigated"); Chicot County Drainage Dist. v. Baxter State Bank, 308 U.S. 371, 376 (1940) (stating that federal courts may determine whether they have jurisdiction but their decision "may not be assailed collaterally").

is See supra note 40.

${ }^{44}$ See, e.g., Ward v. Louisiana Wild Life \& Fisheries Comm'n, 224 F. Supp. 252, 255-58 (E.D. La. 1963) (claim dismissed because an indispensable party had not joined the litigation), affd per curiam, 347 F.2d 234 (5th Cir. 1965). Professor Vestal expressed the opinion that, in addition,

[constitutional] questions are so fundamental that a court may be very re- 
At the other extreme, writers have proposed that, absent significant new evidence, questions of fact and matters of discretion are particularly unsuited for reconsideration and are prime situations in which to invoke law of the case. ${ }^{45}$ As to questions of fact, this Article agrees that law of the case should apply. Reconsideration in these instances seeks mere duplication of effort; none of the reasons for departing from the preclusion principle applies to rulings on questions of fact as such.

Law of the case is not so clearly applicable, however, when a litigant seeks reconsideration of a discretionary matter. ${ }^{46}$ When a trial

luctant to hold that a litigant can be deprived of such rights by a prior erroneous adjudication. The interest of the public and litigants will not allow an individual to be deprived of such rights simply because a court, at an earlier time, made an incorrect legal ruling.

Vestal, supra note 7 , at 29.

4s See, e.g., 18 WRIGHT \& MilleR, supra note 7, § 4478, at 800 (absent significant new evidence, questions of fact are "particularly unsuited to reconsideration"); Vestal, supra note 7, at 23, 26-27 (arguing in favor of application of law of the case to discretionary rulings).

18 The nature of judicial discretion has been the subject of much jurisprudential debate in recent years. Professor Ronald Dworkin identifies three senses of the term "discretion." The first is a "weak sense" in that the standards a person must apply can reasonably be interpreted in different ways and thus demand the use of judgment. The second is also a "weak sense," in that a person has final authority to make a decision and cannot be reviewed and reversed by any other authority. The third is a "strong sense" in that some standards that impose duties on a person "do not purport to impose any duty as to a particular decision." R. DwORKIN, TAKING RIGHTS SERIOUSLY 3132,69 (1977). Clearly all judges often have discretion in the first sense. Trial judges do not have discretion in the second sense; only judges on the system's highest court of appeals are free to exercise that sort of discretion. In Dworkin's view, judges infrequently, if ever, have discretion in the strong sense.

A judge may have discretion in both the first and second senses, and nevertheless properly regard his decision as raising an issue of what his duty as a judge is, an issue which he must decide by reflecting on what is required of him by the varying considerations that he believes are pertinent.

Id. at 69 ; see id. at 71 . The existence of uncertainty as to whether to decide for plaintiff or for defendant does not imply that a judge has discretion to decide for either, as he pleases. Id. at 70. The American system does not employ a rule that judges have discretion in hard cases. Id. at 71 . Sometimes judges do reach the conclusion that they have discretion in the strong sense, because the set of standards they must take into account permit decision for either party. Id. at 70-71.

In such cases judges believe that no one has a right to any particular decision; they identify their task as selecting the decision that is best on the whole, all things considered, and here they talk not about what they must do, but about what they should do. In most hard cases, however, judges take the different posture I described. They frame their disagreement as a disagreement about what standards they are forbidden or obliged to take into account, or what relative weights they are obliged to attribute to these .... There is plainly not even the beginnings of a social rule that converts the discretion that requires judgment into the discretion that excludes duty.

Id. at 71 .

According to one effort to summarize Dworkin's views, judges exercise discretion 
judge or her successor is asked to reconsider a discretionary ruling, the relevant factual or legal context may have further developed, thus raising a different question than was originally posed. ${ }^{47}$ In such a situation, reconsideration should be afforded. That a discretionary matter is at issue should not immunize a ruling from reconsideration. Moreover, even when the very same question is raised, a judge should be able to change her mind and correct her decision on a discretionary matter, particularly if she believes her initial decision constituted an abuse of discretion. The judge can evaluate whether the inefficiency entailed is

only in the weak senses, that is, they must use their judgment to understand and weigh the relevant principles. However, "[b]ecause they are bound by the principles of the system in which they play a role, their decisionmaking process is always limited and structured by those principles." J. Murphy \& J. Coleman, The Philosophy of LAW: AN INTRODUCTION TO JURISPRUDENCE 53 (1984).

Dworkin believes that discretionary decisions, in all three senses of discretion, are never beyond reproach.

The strong sense of discretion is not tantamount to license, and does not exclude criticism. Almost any situation in which a person acts . . . makes relevant certain standards of rationality, fairness, and effectiveness. We criticize each other's acts in terms of these standards, and there is no reason not to do so when the acts are [discretionary in the strong sense] . . . . Someone who has discretion in this third sense can be criticized, but not for being disobedient . . . . He can be said to have made a mistake, but not to have deprived a participant of a decision to which he was entitled

...

R. Dworkin, supra, at 33. See also In re Exterior Siding \& Aluminum Coil Antitrust Litig., 696 F.2d 613, 619 (8th Cir. 1982) ("[D]ecisions, like class certification, which depend heavily on facts and one's view of what they mean-[are] decisions commonly called 'discretionary,' not in the sense that a judge may decide them by whim, but in the sense that different judges, both weighing the same relevant factors, may reasonably come to different conclusions."), vacated en banc on other grounds by an equally divided court, 705 F.2d 980 (8th Gir.), cert. denied, 464 U.S. 866 (1983).

Other valuable writings on discretion include Greenawalt, Discretion and Judicial Decision: The Elusive Quest for the Fetters that Bind Judges, 75 Colum. L. REv. 359, 368 (1975) (arguing that judicial discretion exists in the sense that "there is more than one decision that will be considered proper by those to whom the decision-maker is responsible, and whatever external standards may be applicable either cannot be discovered by the decision-maker or do not yield clear answers to the questions that must be decided"); Rosenberg, Judicial Discretion of the Trial Court, Viewed from Above, 22 SYRACUSE L. REV. 635, 637 (1971) (distinguishing primary discretion, when an adjudicator has "a wide range of choice as to what he decides, free from the constraints which characteristically attach whenever legal rules enter the decision process[,]" from secondary discretion, which "comes into full play when the rules of review accord the lower court's decision an unusual amount of insulation from appellate revision"). Rosenberg argues that primary discretion "permits more compassionate and more sensitive responses to differences which ought to count in applying legal norms, but which get buried in the gross and rounded-off languages of rules that are directed at wholesale problems instead of particular disputes." Id. at 642.

17 See, e.g., Rogers v. Valentine, 426 F.2d 1361, 1363 n.2 (2d Cir. 1970) (law of the case did not preclude trial judge from exercising his discretion to decide, after trial, that a federal court should not exercise pendent jurisdiction over a state law claim, despite contrary decision by a predecessor judge). 
acceptable and can guard against abuse by litigants who may endlessly seek to relitigate every adverse ruling. Having taken these precautions, the judge should be free to change her own discretionary decisions so as to run the case as in her revised view, it should be run. ${ }^{48}$ In fact, the propriety of any single trial judge affording reconsideration of discretionary decisions is generally accepted. ${ }^{40}$

Law of the case is more typically invoked when reconsideration of a discretionary matter is sought from a different judge. Courts and commentators often have regarded it as "improper for a judge to entertain a motion where a like motion has been denied by another judge of coordinate authority [acting in a discretionary capacity] in the same case." "\$o Professor Vestal states, "Generally, . . . a judge with concurrent power should not . . . reverse the exercise of discretion by another judge at an earlier time." ${ }^{\text {"11 }}$ An additional rationale for the protection traditionally given to discretionary rulings relates to the efficiency goals of law of the case, in that the second decision has been said to be no less likely than the first to constitute an abuse of discretion; ${ }^{.52}$ furthermore, the "shopping" of rulings must be discouraged. Like other rulings, however, discretionary decisions may be mistaken. ${ }^{53}$ The second decision is no more likely than the first to constitute an abuse of discretion and indeed, if predicated on more thorough consideration, may well be a better decision. Further, a case may come to a "new" judge in circumstances that negate ruling-shopping by a litigant. ${ }^{54}$ Thus, a change

48 By hypothesis, the judge is dealing with a question as to which it can be said, at the very least, that her duty is defined by standards that she, as a reasonable person, can interpret in different ways. See supra note 46 . If it is unclear what standards are applicable or what relative weight they merit, or if existing standards permit decision for either party, a judge quite reasonably could change her mind upon further reflection.

19 See, e.g., United States v. Williams, 728 F.2d 1402, 1406 (11th Cir. 1984) (" $[\mathrm{A}]$ court's previous rulings may be reconsidered as long as the case remains within the jurisdiction of the district court."); Loumar, Inc. v. Smith, 698 F.2d 759, 762 (5th Cir. 1983) (a predecessor judge always could have reconsidered his initial decision so long as the case remained in his court); Dictograph Prods. Co. v. Sonotone Corp., 230 F.2d 131, 134 (2d Cir.) ("No one will suggest that the first judge himself may not change his mind and overrule his own order."), cert. dismissed, 352 U.S. 883 (1956); Vestal, supra note 7, at 16.

so Wilson v. Ohio River Co., 236 F. Supp. 96, 98 (S.D.W. Va. 1964) (voluntary dismissal) (emphasis added).

s1 Vestal, supra note 7, at 26.

52 Discretionary decisions of the second judge are tested on appeal against the usual abuse of discretion standard. See Loumar, Inc. v. Smith, 698 F.2d at 763; Champaign-Urbana News Agency, Inc. v. J.L. Cummins News Co., 632 F.2d 680, 683 (7th Cir. 1980).

ss See R. Dworkin, supra note 46, at 33.

s4 See, e.g., Peterson v. Lindner, 765 F.2d 698, 700-02 (7th Gir. 1985) (A suit filed in the Western District of Wisconsin was transferred to the Eastern District of 
of judge should not by itself preclude reconsideration of discretionary rulings.

Finally, modifications of discretionary rulings should not significantly undermine the values served by consistency in judicial decisions. Because of the discretionary nature of the determinations, that is, the personal judgment they entail and, in some circumstances, the absence of standards that impose a duty to make a particular decision, people other than the immediate litigants, in their own factually unique contexts, cannot firmly rely upon discretionary rulings to guide their own conduct. Nor should judicial differences of opinion undermine public confidence when, by definition, the matters in question are ones about which reasonable minds can differ. For the same reason, a difference of opinion should not be regarded as any sign of disrespect for another jurist. Consequently, at least when the judge with ongoing responsibility for a case believes that the initial ruling constitutes a clear abuse of discretion, she should not have her hands tied by rulings of a predecessor, ${ }^{\text {bs }}$ simply because they were discretionary. Any short-term inefficiencies created by reconsideration are outweighed by the probability of long-term savings gained through avoiding appellate reversal, by the improved quality of justice afforded the litigants, and by the intangible advantages of allowing a judge to run a case as she believes is right or best.

In light of this analysis, courts applying law of the case principles should focus on the following inquiries in order to determine whether reconsideration of a given issue should be denied:

(1) Has the law or have the facts upon which a ruling now would be based changed from what they were, or were thought to be, at the time of the initial decision? Was the original decision avowedly preliminary or tentative, in expectation of such changes?

(2) May the issue be immediately determinative of the outcome of the case, or is it otherwise so important, either inherently or to the further course of the proceedings, as to warrant reconsideration?

(3) Is the prior ruling clearly erroneous, manifestly unjust, or a

Wisconsin because of an overloaded docket; when the workload subsided, the case returned to the Western District. The judge initially assigned to the case after the return was disqualified, however, so that the case had to be reassigned to another judge.); United States Gypsum Co. v. Schiavo Bros., 668 F.2d 172, 175 (3d Cir. 1981) (resignation of judge), cert. denied, 456 U.S. 961 (1982); United States v. Desert Gold Mining Co., 433 F.2d 713, 714 (9th Cir. 1970) (death of predecessor judge); Tanner Motor Livery, Ltd. v. Avis, Inc., 316 F.2d 804, 807 (9th Cir.) (new judge appointed because prior judge was on extended vacation), cert. denied, 375 U.S. 821 (1963).

${ }_{B S}$ This standard parallels the generally recognized exception to law of the case doctrine for rulings that are clearly erroneous. See infra note 60. 
clear abuse of discretion?

(4) Is the issue of such a nature that a different ruling would disappoint justified expectations, prejudice any of the parties, or undermine respect for the law and the courts?

(5) To what extent will the case's progress toward judgment be impeded by reconsideration? and

(6) How much duplication of effort is entailed?

\section{B. Conflicts Among the Circuits}

The Supreme Court has not considered the intricacies of law of the case doctrine at length or in decisions having broad precedential value. ${ }^{\text {se }}$ Consequently, courts of appeals and district courts have had

so The U.S. Supreme Court has addressed the doctrine of law of the case in several different settings. At times the Court has attempted to clarify the nature and scope of the doctrine. See, e.g., Arizona v. California, 460 U.S. 605, 618-19 (1983) (Court's power to modify a decree determining the apportionment of Colorado River water should not be exercised in accordance with law of the case principles; to extend the doctrine "wholesale" into cases within the Court's original jurisdiction would weaken intolerably the finality of its decrees, particularly in cases turning on statutory equitable criteria); Johnson v. Board of Educ., 457 U.S. 52, 53-54 (1982) ("Because we have vacated the Court of Appeals' judgments in this case, the doctrine of the law of the case does not constrain either the District Court, or should an appeal subsequently be taken, the Court of Appeals."); Firestone Tire \& Rubber Co. v. Risjord, 449 U.S. 368, 381 (1981) (Rehnquist, J., concurring) (A motion to disqualify counsel on the basis of conflict of interest was denied. The Court noted that, although the ruling was not immediately appealable, "[T]he District Court remains free to reconsider its decision at any time."); Quern v. Jordan, 440 U.S. 332, 347 n.18 (1979) (Court-approved notice to plaintiff class members did not violate law of the case as it was not a matter previously determined on appeal to a higher court: "The doctrine . . . comes into play only with respect to issues previously determined," nor was notice inconsistent with the prior high court decision.); Alexis I. du Pont School Dist. v. Evans, 439 U.S. 1375, 1376 (1978) (when considering a reapplication for a stay of a desegregation order, Justice Rehnquist refused to consider any law of the case implications in the Court's prior summary affirmance of the case); Turner v. Arkansas, 407 U.S. 366, 368 (1972) (Arkansas Supreme Court erred by declining to consider the applicability of a controlling, intervening U.S. Supreme Court decision and holding that its own prior decision was law of the case); United Gas Improvement Co. v. Continental Oil Co., 381 U.S. 392, 405 (1965) (jurisdictional questions not foreclosed by the law of the case doctrine); United States v. U.S. Smelting Refining \& Mining Co., 339 U.S. 186, 198-99 (1950) (law of the case was not applicable and did not require affirmance of district court order invalidating Interstate Commerce Commission orders where there had been no "final" judgment and no interlocutory appeal from the district court's grant of a temporary injunction and remand to the Commission; while the injunction could have been appealed under 28 U.S.C. § 1253, the fact that it was not did not make the order law of the case); Messenger v. Anderson, 225 U.S. 436, 443-44 (1912) (when the court of appeals had before it a will that it previously had construed and, in the interim, the highest court of the state in which the affected real estate was situated also had construed the will, the court of appeals was not bound to adhere to its previous decision as the law of the case); Remington v. Central Pac. R.R., 198 U.S. 95, 99-100 (1905) (if circuit court was satisfied that it or its predecessor state court had made a mistake, it was not precluded by law of the case doctrine but had the power to reopen the question and to set aside 
considerable freedom to mold the doctrine. Although there is substantial consensus on the doctrine's nature and operation, a review of the cases indicates that the courts of appeals and their federal district courts define and apply the doctrine with varying degrees of stringency.

Some circuits take a relatively lax attitude toward law of the case. The Second Circuit leads this group, having the most relaxed doctrine

summons).

The Court has found that rulings by state courts that their decisions are law of the case do not bar Supreme Court consideration of federal questions in those cases. The Court noted that a holding to the contrary would insulate interlocutory state court rulings on important federal questions. See, e.g., Hathorn v. Lovorn, 457 U.S. 255, 262 (1982) (Court can review a federal question determined in the state supreme court where the first decision did not seem final); Reece v. Georgia, 350 U.S. 85, 87 (1955) (Supreme Court not bound by state high court's ruling that the state court's decision was the law of the case); Davis v. O'Hara, 266 U.S. 314, 321 (1924) ("The ruling that the former decision of the state court became the law of the case does not affect the power of this Court to reexamine the question.").

On occasion, the Court has set forth broad general statements regarding law of the case. See, e.g., Arizona v. California, 460 U.S. at 644 (Brennan, J., concurring in part and dissenting in part) ("In the absence of some overriding reason, a court should be reluctant to reopen that which has been decided merely to correct an error, even though it has the power to do so."); United States v. Goodwin, 457 U.S. 368, 376 (1982) ("The doctrines of stare decisis, res judicata, the law of the case, and double jeopardy are all based, at least in part, on that deep seated bias [inherent in the judicial system against the retrial of issues that have already been decided]."); Messenger v. Anderson, 225 U.S. at 444 ("[L]aw of the case, as applied to the effect of previous orders on the later action of the court rendering them in the same case, merely expresses the practice of courts generally to refuse to reopen what has been decided, not a limit to their power."); Remington v. Central Pac. R.R., 198 U.S. at 100 ("However stringent may be the practice in refusing to reconsider what has been done, it still is but practice, not want of jurisdiction, that makes the rule.").

The Court distinguished the doctrine of law of the case from res judicata in Southern Ry. v. Clift, 260 U.S. 316 (1922), when a defendant attempted to raise res judicata as a bar to Supreme Court review. "The prior ruling may have been followed as the law of the case but there is a difference between such adherence and res judicata; one directs discretion, the other supersedes it and compels judgment. In other words, in one it is a question of power, in the other of submission." Id. at 319.

The Supreme Court has corrected improper applications of the law of the case doctrine. For example, in Theard v. United States, 354 U.S. 278, 282 (1957), the district court held that state court proceedings disbarring the plaintiff were law of the case and that plaintiff also should be barred from federal practice. The Supreme Court, however, held that in the circumstances of the case, "the law of the case" did not require a federal court's automatic acceptance of a state disbarment decision. See also Davis v. United States, 417 U.S. 333, 342 (1974) (court of appeals erred in holding that the law of the case, as determined in an earlier appeal, precluded petitioner from securing relief on the basis of an intervening change in law).

Finally, the Supreme Court has invoked the law of the case doctrine as a bar to reconsideration of issues it has already decided in a prior review of a case. See Insurance Group Comm. v. Denver \& R.G.W.R.R., 329 U.S. 607, 612 (1947) ("While power rests in a federal court that passes an order or decision to change its position on a subsequent review in the same cause, orderly judicial action, except in unusual circumstances, requires it to refuse to permit the relitigation of matters or issues previously determined on a former review."). 
as to the reconsideration of district court rulings. Since 1956, when Judge Hand delivered the court's opinion in Dictograph Products Co. v. Sonotone Corp., ${ }^{57}$ the Second Circuit has taken the position that law of the case doctrine need not be applied as long as the departure from a prior ruling will not prejudice the party seeking the benefit of the doctrine. ${ }^{58}$ Several courts of appeals, including the First, Fourth, Fifth, and Seventh through the Eleventh Circuits, take a tougher stance. These circuits have recognized that, in general, courts should not reconsider issues that already have been decided in an action. They profess to depart from this general rule only when particular, well-defined exceptions are present. The most widely recognized exceptions include a contrary decision of the applicable law by controlling authority or a change or development in the underlying facts, ${ }^{50}$ the clearly erroneous

s7 230 F.2d 131 (2d Cir.), petition for cert. dismissed, 352 U.S. 883 (1956). In this case the appellate court held that the initial judge's denial of defendant's motion for summary judgment did not preclude the successor judge from granting the motion on the merits. See id. at 134-36.

s8 See, e.g., United States v. Birney, 686 F.2d 102, 107 (2d Cir. 1982) (the only limit on a trial judge's decision to disregard a previous ruling by a judge of coordinate jurisdiction is that prejudice not ensue); First Nat'l Bank v. American Foam Rubber Corp., 530 F.2d 450, 453 n.3 (2d Cir.) ("[T] he law of the case is a discretionary doctrine that need not be applied when no prejudice results from its omission."), cert. denied, 429 U.S. 858 (1976). The Sixth Circuit may also have adopted this more relaxed approach, if one is to judge from language in Benoay v. Decker, Nos. 81-1506, 82-1021, 82-1039, (6th Cir. May 30, 1984) (available on WESTLAW, Allfeds, 6th Cir.; LEXIS, genfed library, Cir. file; not recommended for full-text publication). In this decision, the court emphasized that the doctrine is not an inexorable command, but merely expresses the general practice of refusing to reopen what has been decided. The only restraint upon a second judge is one of comity. The appellate court concluded that "a second judge is not bound by the decisions of a prior judge on the same issue." District court opinions within the Sixth Circuit, however, take a tougher stance, more typical of the middle-of-the-road circuits. See, e.g., Kuenz v. Goodyear Tire \& Rubber Co., 617 F. Supp. 11, 14 (N.D. Ohio 1985) ("When issues have been carefully considered and decisions rendered, the only reason which should commend reconsideration of that decision is a change in the factual or legal underpinnings upon which the decision was based."); accord, Michigan Paralyzed Veterans v. Coleman, 545 F. Supp. 245, 248 (E.D. Mich. 1982) ("[W] to the entry of an Order, that judicial determination may be subject to review . . ..").

${ }^{89}$ See In re Peterson v. Lindner, 765 F.2d 698, 704 (7th Cir. 1985) (given new evidence or controlling law, or clear error, law of the case must yield); Loumar, Inc. v. Smith, 698 F.2d 759, 762 (5th Cir. 1983) (a court will follow a ruling unless it was erroneous, is no longer sound, or would work an injustice); Multi-Piece Rim Prods. Liab. Litig., 653 F.2d 671, 678 (D.C. Cir. 1981) (holding that adherence to law of the case is within the discretion of the court when the law has changed or new evidence has been introduced); Gallimore v. Missouri Pac. R.R., 635 F.2d 1165, 1172 (5th Cir. 1981) ("if the facts or circumstances have changed significantly in the interim-e.g., because of a better-developed record, or a change or clarification in the applicable law from a higher court-the second judge is not truly overruling the first"); Yankton Sioux Tribe of Indians v. Nelson, 604 F. Supp. 1146, 1155 (D.S.D. 1985) ("A prior decision in a case is the 'law of the case' in all subsequent proceedings unless: (1) The evidence . . . is substantially different from that first considered by the court, or (2) 
or unjust nature of the prior decision, ${ }^{60}$ the immediately dispositive nature of an issue, ${ }^{61}$ and the avowedly preliminary character of prior rulings. ${ }^{62}$ Although it is difficult to document, one senses that while these

The prior decision is clearly erroneous and works manifest injustice."); United States v. Eilberg, 553 F. Supp. 1, 3 (D.D.C. 1981) (stating that a district court may overrule an earlier decision in exceptional circumstances); Eckl v. City of Boston, 476 F. Supp. 1014,1017 (D. Mass. 1979) (holding that law of the case cannot be relied upon where it would result in a grave injustice); see also Robinson v. Parrish, 720 F.2d 1548, 1550 (11th Cir. 1983) (stating that a court is not bound to adhere to its earlier rulings but can consider new developments or simply change its mind); Major v. Benton, 647 F.2d 110,112 (10th Cir. 1981) (while law of the case requires courts to follow a rule throughout proceedings, if a lower court thinks that its interlocutory ruling is substantially erroneous, it can correct it); Tanner Motor Livery, Ltd. v. Avis, Inc., 316 F.2d 804, 809-10 (9th Cir.) (stating that a district court judge may overrule an interlocutory decision of another district court judge only for "the most cogent reasons"), cert. denied, 375 U.S. 821 (1963); Sherrill v. Brinkerhoff Maritime Drilling, 615 F. Supp. 1021, 1025 (N.D. Cal. 1985) (U.S. Supreme Court decision required reexamination of assumption on which court acted); Dynalectron Corp. v. United States, 4 Cl. Ct. 424, 431 (law of the case not strictly applied when there has been no final judgment), affd mem., 758 F.2d 665 (Fed. Cir. 1984); E.D.S. Fed. Corp. v. United States, 2 Cl. Ct. 735,737 (1983) (stating that law of the case applies unless evidence is different, controlling authority has changed, or the decision was clearly erroneous). But see In re Plantation Manor Restaurant, 45 Bankr. 229 (Bankr. E.D. and W.D. Ark. 1984) (successor court refused to overturn a ruling of the prior judge on grounds of courtesy and respect for the judge).

60 See the cases cited supra note 59; United States v. Williams, 728 F.2d 1402, 1406 (11th Cir. 1984) (when case is transferred from one judge to another, law of the case does not bind the second judge to an erroneous ruling); Hill v. BASF Wyandotte Corp., 696 F.2d 287, 290 n.3 (4th Cir. 1982) ("Whether rulings by one district judge become binding as 'law of the case' upon subsequent district judges is not a matter of rigid legal rule, but more a matter of proper judicial administration which can vary with the circumstances. . . . But we have not held that the 'law of the case' doctrine is so related to the very power of the second judge that we must in review affirm even a legally erroneous ruling because it was compelled as "law of the case." "); ChampaignUrbana News Agency, Inc. v. J.L. Cummins News Co., 632 F.2d 680, 683 (7th Cir. 1980) (law of the case is not so rigid that it cannot be ignored when a court wishes to correct an error); Burns v. Massachusetts Inst. of Technology, 394 F.2d 416, 418 (1st Cir. 1968) (a court may change its decison because of error); Gastner v. First Nat'l Bank, 278 F.2d 376, 379-80 (9th Cir. 1960) (no abuse of discretion when a judge overruled a prior order because of an error in law).

61 See Champaign-Urbana News Agency, Inc., 632 F.2d at 683 (correct to reconsider issue of jurisdiction); Commerce Oil Refining Corp. v. Miner, 303 F.2d 125, 128 (1st Cir. 1962) ("A ruling denying a motion to dismiss is not the law of the case, and is not final even in the district court."); Common Cause v. Bolger, 512 F. Supp. 26, 28 (D.D.C. 1980) (where "it can be shown that controlling authority has subsequently taken a clearly contrary view of the issue," a motion to dismiss on jurisdictional grounds can be reviewed), aff'd, 461 U.S. 911 (1983).

62 See Peterson v. Lindner, 765 F.2d 698, 704 (7th Gir. 1985) (judge may reconsider interlocutory decison at any time); Marathon Petroleum Co. v. LoBosco, 623 F. Supp. 129, 131 (N.D. Ill. 1985) (law of the case did not bind court to accept fact findings made in hearing for preliminary injunction); Dynalectron Corp. v. United States, 4 Cl. Ct. 424, 431 (law of the case applied because "[t]he rulings did not come on a request for temporary or preliminary extraordinary relief'), aff'd mem., 758 F.2d 665 (Fed. Cir. 1984). 
circuits use the same verbal formulae, they-or at least particular district courts and judges within the circuit-apply the tests with a considerable range of exactitude.

Finally, it appears that the Third Circuit is still more stringent in that it may not yet recognize the "clearly erroneous" exception. ${ }^{63} \mathrm{Al}-$ though the Third Circuit has noted that the Supreme Court "approved" this exception, it was speaking in the context of a case where the doctrine had been argued to bar the Third Circuit itself from considering an issue said to have been determined on a prior appeal. ${ }^{64}$ No case has been found in which the Third Circuit actually has applied the "clearly erroneous" exception. ${ }^{65}$

This Article does not attempt an exhaustive survey of the state of law of the case doctrine in each of the federal circuits and in each dis-

6s See Hayman Cash Register Co. v. Sarokin, 669 F.2d 162, 170 n.10 (3d Cir. 1982); Todd \& Co. v. SEC, 637 F.2d 154, 157 n.4 (3d Cir. 1980). The Third Circuit does, however, recognize exceptions when new evidence is available, a supervening rule of law has been announced, or when the ruling judge has become unavailable. See Hayman, 669 F.2d at 169-70 and cases therein cited.

of See Schultz v. Onan Corp., 737 F.2d 339, 345 (3d Cir. 1984) (The court recognized the Supreme Court's decision in Arizona v. California, 460 U.S. 605 (1983), but based its decision to reconsider the lower court's ruling on the finding of new evidence.). The courts of appeals sometimes apply different and more stringent criteria when the question is whether they should reconsider their own prior rulings than they expect a trial court to apply when asked to depart from its prior ruling. See also 18 WRIGHT \& MILLER, supra note 7, § 4478, at 795-96:

Relationships within a court of appeals demand greater deference to earlier rulings, partly because they typically involve the concurrent judgment of two or more judges, and more importantly because they usually represent a deliberate decision reached in a case that is already well advanced and designed to control further proceedings. . . . [A] new panel may be strongly inclined to follow the rulings of an earlier panel, particularly in a court that has so many members as to fear repeated appeals based simply on the hope of pitting three judges against three others.

os Another court has taken a very stringent view:

A party aggrieved by one judge's ruling has a proper remedy by means of appeal ... ; the review and amendment or reversal of one coordinate judge by another can only stultify the law and cheapen the judicial process, encouraging litigants, at least, to indulge in a form of forum shopping which would exploit and dramatize the philosophical differences among co-equal judges and, at worst, may produce baseless allegations against judges as a means of achieving their disqualification in order to use such coordinate review as a substitute for appeal. The crippling potential for justice is obvious . . . [T] There is a firm basis for this version of the rule which prohibits a transferee judge from reviewing and overruling the decision of another coordinate judge, regardless of the merit of the former decision. This court, for this reason and, further, on the basis of courtesy to a coordinate judge and respect for his decisions, must elect to follow this rule....

In re Plantation Manor Restaurant, 45 Bankr. 229, 231 (Bankr. E.D. and W.D. Ark. 1984). 
trict court. Sufficient research has been done to establish that differences do exist in the courts' attitudes toward the doctrine and in their formulation and application of it, as the preceding discussion reflects. This fact is significant: because no monolithic nation-wide doctrine prevails, courts facing law of the case arguments in cases transferred intercircuit after an issue has been decided need to determine whose law of the case doctrine properly applies. How the courts should go about making that decision, and what conclusion they should reach, are matters explored later in this Article. ${ }^{86}$

\section{Complicating Factors}

Some law of the case problems that arise in multidistrict litigation result whenever a new judge takes over a case, whereas others exist by virtue of cases being consolidated, transferred, or both. Still other problems are unique to multidistrict litigation. This part of the Article explores the law of the case issues raised by a change of judge, consolidation, and transfer, both individually and in combination. Part III will examine how courts involved in multidistrict litigation actually have handled, and should handle, the law of the case issues presented to them.

\section{A. Change of Judge}

We already have observed that before final judgment, a single judge is free to afford reconsideration and to reverse herself on any matter on which she previously has entered an interlocutory ruling, although law of the case doctrine is applicable. ${ }^{67}$ When a different judge confronts a problem decided by another judge earlier in the same litigation, additional policy considerations come into play. Many years ago, the Supreme Judicial Court of Massachusetts wrote, "A judge should hesitate to undo his own work. Still more should he hesitate to undo the work of another judge." reverse" distaste judges have for repeating work which has already been done;

66 See infra notes 99-168 and accompanying text.

67 See, e.g., Diaz v. Indian Head, Inc., 686 F.2d 558, 562 (7th Cir. 1982) (holding that a judge's interlocutory decisions can be reviewed and repealed at any time); United States v. Fine, 243 F. Supp. 785, 787 (S.D.N.Y. 1965) ("When it has been brought to the attention of a court that it was in error . . . the court has an obligation to change its decision."); see FED. R. CIv. P. 54(b); supra note 49.

${ }_{68}$ Peterson v. Hopson, 306 Mass. 597, 603, 29 N.E.2d 140, 145 (1940) (citation omitted).

6o Vestal, supra note 7, at 16. 
the general respect that one judge has for another; [and] the desire for stability in the law."'70 In Vestal's view, these considerations lead to an unwillingness to disregard law of the case doctrine except under the most extraordinary circumstances. ${ }^{71}$

All the factors cited by Professor Vestal are relevant to the problem. Because reconsideration by a new judge ordinarily will require far more time and effort than would reconsideration by the judge who previously ruled on an issue, such requests for reconsideration particularly threaten the efficiency policy supporting law of the case doctrine. In a similar vein, reconsideration by a new judge ordinarily is more likely than reconsideration by the same judge to lead to a change of decision. Consistency and stability in the law are thus particularly threatened by requests for reconsideration by a different judge. Threatened, too, is the desire of judges to accord one another respect. Finally, when a different judge is asked to rule, the need to deter judge-shopping provides an additional factor supporting vigorous implementation of law of the case doctrine.

These considerations initially led to an especially stringent application of law of the case doctrine when a successor judge was asked to reconsider a predecessor's ruling. ${ }^{22}$ Some circuits still set high verbal barriers to reconsideration by one judge of the rulings of another ${ }^{73}$ Even these courts become less wary, however, when it is clear from the unavailability of the initial judge that a litigant has not judge-shopped in hopes of obtaining a more favorable ruling but was forced to seek reconsideration from a different judge if reconsideration was to be had at all. ${ }^{.4}$ By the same token, courts' resistance to reconsideration by a different judge is greatest when the judge who initially ruled is, or soon

${ }^{70}$ Id. at $16-17$.

72 Id. at 17.

72 See, e.g., Commercial Union v. Anglo-South Am. Bank, Ltd., 10 F.2d 937, 938 (2d Cir. 1925) (reversing solely because one district judge had "overruled" an earlier order of another district judge), repudiated in Dictograph Prods. Co. v. Sonotone Corp., 230 F.2d 131, 135-36 (2d Cir.), cert. dismissed, 352 U.S. 883 (1956).

${ }^{73}$ See, e.g., Hayman Cash Register Co. v. Sarokin, 669 F.2d 162, 168 (3d Cir. 1982) ("[J]udges of co-ordinate jurisdiction sitting in the same court and in the same case should not overrule the decisions of each other." (quoting TCF Film Corp. v. Gourley, 240 F.2d 711, 713 (3d Cir. 1957)); Stevenson v. Four Winds Travel, Inc., 462 F.2d 899, 904-05 (5th Cir. 1972) (rule that successor judge should not overrule her predecessor's decisions is essential to respectable administration of the law, to speed conclusion of litigation and to prevent unseemly conflicts); United States v. Desert Gold Mining Co., 433 F.2d 713, 715 (9th Cir. 1970) ("one judge should not overrule another except for the most cogent reasons").

${ }^{74}$ See, e.g., Hayman Cash Register Co., 669 F.2d at 169 n.9; TCF Film Corp. v. Gourley, 240 F.2d 711, 714 (3d Cir. 1957); Peterson v. Hopson, 306 Mass. 597, 603, 29 N.E.2d 140, 145 (1940). 
will be, available to afford reconsideration, ${ }^{75}$ for example, upon return from vacation.

More generally, absent indications of judge shopping, the modern trend is not to treat cases that have been reassigned to a second judge as a special breed, with reassignment immunizing prior rulings. ${ }^{78} \mathrm{Al}-$ though the special force of law of the case doctrine is noted when reconsideration is sought from a "new" judge, reconsideration typically is afforded when the cases present circumstances that fall within the usual exceptions to law of the case doctrine recognized in a particular circuit and usually is denied, absent these exceptional circumstances. ${ }^{77}$ This development reflects judicial recognition of the strong policies that underlie the various exceptions to law of the case doctrine, as well as an often unarticulated evaluation that those policies outweigh the inefficiencies and threats of inconsistent decisions posed by a different judge's reconsideration. The trend also may reflect a consensus that the policies underlying the exceptions outweigh the unspoken desire of some judges to spare the feelings or egos of other judges whose decisions would be found wanting if reexamined ${ }^{78}$ and perhaps at the same time to fend off

75 See, e.g., Tanner Motor Livery, Ltd. v. Avis, Inc., 316 F.2d 804, 810 (9th Cir.) (cogent reasons for reconsideration by a new judge were absent when a motion for order to show cause why a preliminary injunction should not be dissolved and a different preliminary injunction issued could have been heard a few days later, when judge whose ruling was in question returned), cert. denied, 375 U.S. 821 (1963).

76 See 1B MoOre's Federal Practice, supra note 7, If 0.404 [4.-2], at 127-29.

77 See, e.g., Peterson v. Lindner, 765 F.2d 698, 704 (7th Gir. 1985) ("[W]hile a district judge should carefully consider the propriety of re-examining a prior ruling of another district judge in the same case, when good reasons for doing so appear (such as new evidence or controlling law, or clear error), the 'law of the case' doctrine must yield to rational decisionmaking."); Loumar, Inc. v. Smith, 698 F.2d 759, 762-63 (5th Cir. 1983) (no abuse of discretion in reconsideration of motion to dismiss for lack of personal jurisdiction); Champaign-Urbana News Agency, Inc. v. J.L. Cummins News Co., 632 F.2d 680, 683 (7th Cir. 1980) (no abuse of discretion in reconsidering an issue of jurisdiction after case reassignment due to first judge having taken senior status); Castner v. First Nat'l Bank, 278 F.2d 376, 380 (9th Cir. 1960) (no abuse of discretion in reconsidering order when second judge was firmly convinced that an error of law had been committed); Dictograph Prods. Co. v. Sonotone Corp., 230 F.2d 131, 134-35 (2d Cir.) (Upon appeal of second judge's grant of summary judgment after first judge's denial, appellate court considered whether the second decision was correct, rather than whether first denial was law of the case. Rejecting the notion that a second judge should defer to the ruling of the first as a matter of mutual respect, Judge Hand wrote, "[J]udicial sensibilities should play no part in the disposition of suitors' rights."), cert. dismissed, 352 U.S. 883 (1956); see also Vestal, supra note 7, at 19-20 (an inferior court should apply the correct law regardless of earlier rulings on the matter; it is highly questionable for a judge to avoid his responsibility by talking in terms of an earlier ruling by another judge).

${ }^{78}$ See Loumar, Inc., 698 F.2d at 762 (stating as reason for allowing review by successor judge the fact that predecessor judge could have reconsidered his initial decision, so his decision should not bind a successor "with jurisprudential straps stronger than those that compel him to adhere to an opinion once rendered"). 
peer criticism of their own work. These motivations may be camouflaged in the language of comity and of respect due the work of colleagues on the bench. ${ }^{78}$

Consequently, whenever reconsideration is sought from a judge other than the one who originally ruled, the courts should appreciate that some of the factors pertinent whenever law of the case is raised are particularly salient when a new judge is involved. As a result, the following additional circumstances deserve consideration:

(1) Under what circumstances has the case come before the successor judge? Do they suggest an effort to shop for more favorable rulings?

(2) Is reconsideration now, or soon to be, available from the judge who initially ruled?

(3) If so, is it preferable for the initial judge to make the decision as to whether reconsideration should be afforded and to give such reconsideration as is warranted? The length of time since the initial ruling, subsequent developments in the case or in the law, relative workloads, and other circumstances all may be pertinent in this connection.

Although the grounds for these inquiries are relatively self-evident, some elaboration is appropriate. The first two questions obviously are designed to deter judge shopping. But under what circumstances should judge shopping be suspected? If the change in judge is permanent and due to factors beyond the influence of the parties, such as the judge's death or reassignment of the case for administrative reasons, one would ordinarily not suspect judge shopping. If the change in judge is influenced by a party, the possibility of judge shopping is greater. Even here, however, blind invocation of law of the case would be mistaken. The preeminent example of a suspicious party-influenced change in judge is a change resulting from recusal at the instance of the party now seeking reconsideration. Yet, given the grounds for recusal, ${ }^{80}$ the very fact that a judge did recuse herself may furnish support for reconsideration of her rulings. ${ }^{81}$

79 To the extent that invocation of collegial respect also masks a desire to avoid work or reluctance to make hard decisions, it again is an unworthy and makeweight argument.

${ }_{80}$ Recusal is governed by 28 U.S.C. $\S \S 144$ (1982) and 455 (1982 \& Supp. III 1985 ), which dictate that a federal judge shall disqualify herself in any proceeding in which her partiality might reasonably be questioned, as well as in any of several other specified circumstances. Generally speaking, recusal is required when a judge has a personal bias or prejudice concerning a party, personal knowledge of disputed evidentiary facts, a professional connection with the matter, or directly or indirectly has an interest that could be affected by the outcome of the case.

81 See Mississippi Power Co. v. Peabody Coal Co., 69 F.R.D. 558, 560-63, 56768 (S.D. Miss. 1976) (successor judge, brought in when original judge recused himself, 
Determining the present or near future availability of the judge who first ruled can also deter judge shopping, minimize inefficiency and duplication of effort, and promote consistency in rulings. A second judge should not warmly receive a litigant who needlessly seeks reconsideration when the judge who first ruled is away on a brief vacation. By contrast, even if the prior judge on a case is or soon will be available, so much time may have elapsed since she ruled that little or no efficiency would be gained by referring a matter to her. In this and other circumstances, the mix of facts and law presented may have so changed that neither consistency nor efficiency is at stake.

Despite the propriety of the foregoing considerations, there should be no presumption against reconsideration merely because the presiding judge has changed. The circumstances that typically justify a departure from law of the case ordinarily will also justify a departure when the presiding judge has changed. This discussion so far has focused on situations in which the ruling proposed to be reconsidered was rendered by one judge of the district and division where a single case is pending and has been brought for reconsideration to another judge of the same court. The proper determination of law of the case issues becomes more difficult, however, when a case presents other variables such as a change in the collection of claims presented or a change in court accompanied by a conflict of laws.

\section{B. Consolidation}

Let us turn to the situation in which a ruling is up for reconsideration before the same judge who delivered it, in the district and division where the case still is pending, but where the case has since been consolidated with other cases pending in the same district and division, pursuant to Federal Rule of Civil Procedure $42 .{ }^{82}$ In this way, the

\footnotetext{
could alter ruling permitting discovery).

82 When actions involving a common question of law or fact are pending before the court, it may order a joint hearing or trial of any or all the matters in issue in the actions; it may order all the actions consolidated; and it may make such orders concerning proceedings therein as may tend to avoid unnecessary costs or delay.
}

FED. R. CIv. P. 42(a).

This Rule may be invoked only when cases are pending in a single judicial district and division, for only then can they be "pending before the court." See, e.g., SwindellDressler Corp. v. Dumbauld, 308 F.2d 267, 273 (3d Cir. 1962) (under Rule 42(a), a cause of action pending in one jurisdiction cannot be consolidated with a cause of action pending in another jurisdiction); In re Penn Cent. Commercial Paper Litig., 62 F.R.D. 341, 344 (S.D.N.Y. 1974) (under Rule 42(a) court lacked power to consolidate a case pending before it for all purposes with a case commenced elsewhere and transferred to it under $\$ 1407$ for pretrial purposes only), affd mem., 515 F.2d 505 (2d Cir. 1975); 9 
variable of a change of judge $\mathrm{e}^{83}$ and those introduced by transfer are for the moment eliminated.

A distinction should be made between case consolidations that raise special law of the case issues and consolidations that require only the application of traditional law of the case principles. Whether or not the ruling in question conflicts with rulings previously made in the other consolidated cases, motions may be filed that seek reconsideration of the ruling within the context of its "case of origin," or that seek to extend the ruling from its "case of origin" to the other consolidated actions. When reconsideration within the "case of origin" is involved and a change of ruling would not affect the other consolidated actions, as when the ruling in question relates solely to legal or factual matters not common to the consolidated cases, consolidation does not affect the law of the case problem. Reconsideration should be decided according to ordinary law of the case principles, uncomplicated by other factors. By contrast, when effects on the other consolidated actions are likely, the propriety and wisdom of adhering to a prior ruling within the "case of origin" must be evaluated by reference to matters beyond those at the core of law of the case doctrine. Similarly, when litigants raise questions about the binding effect of a ruling beyond its "case of origin," that is, on the other consolidated actions, additional considerations must be addressed.

Before reaching the law of the case issues in any consolidation context, courts must realize as a preliminary matter that Rule 42 consolidation does not render rulings in one case also rulings "in" the other consolidated actions. Hence, a request for a ruling on the same point in one of the other consolidated actions does not trigger law of the case principles. ${ }^{84}$ This position is consistent with the general principle that consolidation does not effect a "merger" of the consolidated actions. ${ }^{85}$ Moreover, a contrary answer could raise a substantial constitu-

WRIGHT \& MilleR, supra note $7, \S 2382$, at 257 . Of course, matters may be pending in a single judicial district and division because they were commenced there and remained or by virtue of having been transferred there pursuant to 28 U.S.C. $\S 1404$ (1982) or 28 U.S.C. § 1406 (1982).

8s Prior to consolidation, the other cases may have been before other judges. If such another judge made a ruling in conflict with the ruling "nominated" for reconsideration, a "change of judge" component also is introduced. See infra text following note 89.

84 See MacDonald v. Follett, 193 S.W.2d 287, 287-88 (Tex. Civ. App. 1946) (judgment of state supreme court on a prior appeal in one of two suits consolidated for trial was "law of the case" on only that branch of the consolidated suit).

ss [M]erger is never so complete even in consolidation as to deprive any party of substantial rights which he may have possessed had the actions proceeded separately. The actions retain their separate identity, and the parties and pleadings in one action do not automati- 
tional problem. Parties to the other consolidated actions who are neither parties nor in privity with parties to the "case of origin" did not have their day in court, their opportunity to be heard before the initial ruling was rendered. If, through consolidation, an adverse ruling automatically became the law in their cases and law of the case doctrine were held to preclude reconsideration, these litigants' due process rights would be infringed. ${ }^{88}$

Despite the courts' strong inclination to bring harmony and uniformity to the rulings in a set of consolidated cases, when a court contemplates extending a ruling that is adverse to "new" parties in the other consolidated cases, all interested parties should be heard, without hindrance from law of the case. While stare decisis is applicable, it does not deny the "new" parties a hearing. By contrast, if an earlier judicial ruling went against persons who are also parties to a case that since has been consolidated with the "case of origin," and if the adversely af-

cally become parties and pleadings in the other action.

5 Moore's Federal Practice, supra note 7, § 42.02[3], at 42.28-42.29 (footnotes omitted) and cases therein cited. See Johnson v. Manhattan Ry., 289 U.S. 479, 496-97 (1933) (consolidation "does not merge the suits into a single cause, or change the rights of the parties, or make those who are parties in one suit parties in another' "); United States v. Altman, 750 F.2d 684, 696 (8th Cir. 1984) (appointment of receiver in one action did not affect right of parties in other consolidated actions to enter into settlements); Kraft, Inc. v. Local Union 327, 683 F.2d 131, 132-33 (6th Cir. 1982) (district court erred in treating consolidation as an attempt by a plaintiff employer impermissibly to join a union, the third party beneficiary of a contract, as party to a suit in which the real party in interest was a litigant; moreover, termination of employer's suit, but not the other consolidated action, was a final appealable order not requiring Rule 54(b) certification); McKenzie v. United States, 678 F.2d 571, 574 (5th Cir. 1982) (consolidation of improperly removed state suit with a federal suit did not confer subject matter jurisdiction over the former).

${ }^{88} C f$. Hansberry v. Lee, 311 U.S. 32, 40-42 (1940) (due process requirements prevent persons not before the court personally or through an adequate representative from being bound by the judgment); Hardy v. Johns-Manville Sales Corp., 681 F.2d 334, 337-39 (5th Cir. 1982) (defendant asbestos manufacturers in consolidated litigation who were not parties to prior asbestos litigation in which other plaintiffs prevailed, could not be collaterally estopped by determinations made in that prior litigation, even though other defendant manufacturers in the consolidated cases had been parties to the prior litigation); Capital Investors Co. v. Estate of Morrison, 584 F.2d 652, 654 (4th Cir. 1978) (decision imposing a constructive trust on promissory notes was held binding, under law of the case, against persons who had intervened after decision was made, but only after they had been given the opportunity to relitigate the issue and had failed to produce any new evidence), cert. denied, 440 U.S. 981 (1979). The dissent in the Capital Investors case argued that the district judge had acted properly in reconsidering the evidence because there were new parties in the case, and further, that the appellate court erred in effectively shifting to the newcomers the burden of proving incorrect the previous fact findings in a case to which they were not parties. Id. at 657-58. "I do not think previous fact finding can bind a person who is not a party to the case to his detriment . . . absent at the very least a complete reconsideration of the record as a whole plus the opportunity to present evidence ...." Id. at 658 (Widener, J., dissenting). 
fected parties had a full and fair opportunity to litigate the issue, they could be collaterally estopped from relitigating the identical issue in the newly consolidated cases. ${ }^{87}$ Technically, however, this is not law of the case.

But let us return to the effects of consolidation when law of the case is applicable. Uniformity is critical to the administrability and efficiencies that Rule 42 consolidation was designed to foster. ${ }^{88}$ In evaluating adherence to a prior ruling, the usual law of the case principles must be applied or modified to reflect not only the need for horizontal consistency among consolidated cases but also the recognition that what may have been best for-or acceptable in-one case alone, may not be the optimal, or even a satisfactory, treatment of the consolidated cases as an aggregate.

Such application or modification of law of the case is consistent with law of the case's basic concerns with promoting efficiency and preserving consistency. Absent any other traditional ground for departing from the doctrine, the inefficiencies of reconsideration should be shouldered only when warranted by the gain in time, effort, and justice obtained from imposing uniformity in the adjudication of consolidated cases. Furthermore, alteration of pre-consolidation decisions does not

${ }^{87}$ In Zdanok v. Glidden Co., Durkee Famous Foods Div., 327 F.2d 944 (2d Cir.), cert. denied, 377 U.S. 934 (1964), for example, the appellate court had held that a collective bargaining agreement had been breached in $Z$ danok, a case consolidated for trial, after remand, with a second case. On a second appeal, the court adhered to its construction of the contract under "law of the case," finding no reason why that doctrine "should be peremptorily excluded because of the presence of new parties when the party against whom it is invoked was fully heard on a prior appeal," so long as the two cases were the same in other respects. Id. at 953. Furthermore, because the defendants were collaterally estopped from introducing any new evidence on the issue of liability in the second case, the court concluded that the two consolidated cases were so much the same that its former holding on liability in Zdanok was also "law of the case" in the second. Id. at 954-56. As to collateral estoppel generally, see FrIEDENTHAL, supra note 8, §§ 14.9-14.14, at 658-93; see also City of Parma v. Levi, 536 F.2d 133, 134-35 (6th $\mathrm{Cir}$. 1976) (when plaintiff attempts to bring a dismissed count as a new complaint in order to obtain a right of immediate appeal, district court should consolidate the two actions and dismiss the second under law of the case).

88 Consolidation is available to enhance the ability of the courts to act with expedition and economy while providing justice to the parties. See 9 WRIGHT \& MILLER supra note $7, \S 2381$, at $253, \S 2383$ at 259 . Rule 42 's requirement of a common question of law or fact shows the importance of uniformity in the claims presented and in the law applied. Courts are reluctant to consolidate when the common issue is not a central one, when many of the parties differ, or when different bodies of law will apply. See, e.g., Shumate \& Co. v. National Ass'n of Sec. Dealers, 509 F.2d 147, 155 (5th $\mathrm{Cir}$ ) (no abuse of discretion in denial of consolidation where issues were separate and numerous defendants differed), cert. denied, 423 U.S. 868 (1975); Flintkote Co. v. Allis-Chalmers Corp., 73 F.R.D. 463, 465 (S.D.N.Y. 1977) (consolidation of contract actions denied where contracts and alleged breaches differed in important respects and different states' laws might apply). The less the uniformity, the less time and expense is saved by consolidation. 
necessarily demonstrate vacillation or inconsistency in the law, for the consolidated cases may present a mix of law or fact that is new and different in relevant respects from the mix presented by any one particular component of the consolidation.

Consequently, a court faced with an apparent law of the case problem should first ask whether the requested ruling is on an issue that has been previously decided in the particular case, and not merely in another component of the consolidation. Only in this circumstance should the court consider the set of factors pertinent to law of the case problems. Irrespective of whether a law of the case problem is present, however, the court should also consider whether ease of administration, enhanced efficiency, and horizontal consistency among the consolidated cases indicate a particular outcome on the underlying issue presented. ${ }^{\mathbf{8 9}}$

Finally, where preconsolidation rulings have been rendered by different judges of a district and division, the litigants may ask that these rulings be reconsidered or extended to the other consolidated actions by the judge to whom the collection of consolidated cases has been assigned. In that event, in addition to all of the factors discussed in this section of the Article, the judge should also consider those matters pertinent when there has been a change of judge. Usually, those factors will not change the result: case consolidation is not ordinarily the product of litigants' shopping for a favorably disposed judge. The fact that consolidation results in a change of judge should not lead to an especially guarded attitude toward reconsideration. In addition, while the predecessor judge may be available, consolidation often changes the issue presented so that the interests of efficiency and consistency do not mandate referring the question to the judge who earlier ruled. For the same reason, neither the judge who ruled in an individual case nor the public should view the alteration of a decision as expressing lack of respect for an individual judge or for the judicial process. If more than one predecessor judge exists, such reference becomes entirely unworkable. Moreover, to refer issues to the judges involved earlier radically undermines the purposes of consolidation. Consequently, the handling of a challenged ruling ordinarily will turn, not on whether there has been a change of judge, but rather on the usual law of the case concerns, supplemented by the special factors made relevant by the consolidation.

\section{Transfer}

Transfer of cases poses other conundra. Under sections 1404 and

${ }^{89}$ Our analysis of multidistrict litigation will furnish examples of these principles in action. See infra notes 233-60 and accompanying text. 
1406 of the federal code, ${ }^{80}$ a federal district court may transfer a civil action to any district or division where it might have been brought. The transfer may be within or beyond the region served by a single federal court of appeals. The transferee court takes the case "as is," and proceeds with it. ${ }^{91}$ Although it is theoretically possible for the transferee court to transfer the case to yet another district court in which it might have been brought, ${ }^{92}$ a case ordinarily remains in the first transferee court until settled or finally adjudicated.$^{93}$ After transfer, a litigant may seek reconsideration of one or more rulings made by the transferor judge.

Basic law of the case doctrine must be supplemented after a change of venue because transfer raises choice of law issues, implicates appellate jurisdictional limits, and may be a result of forum-shopping. It also sometimes requires determination of the deference due rulings rendered by a court that lacked jurisdiction or was an improper venue. In considering the complexities attendant upon law of the case doctrine in the context of transfers, it is necessary to distinguish transfers under section 1404 from those under section 1406.

\section{Section 1404 Transfers}

For the purposes of this discussion, let us assume first that the transferor court had federal question subject matter jurisdiction over

20 Under 28 U.S.C. § 1404(a) (1982), "For the convenience of parties and witnesses, in the interests of justice, a district court may transfer any civil action to any other district or division where it might have been brought."

Under 28 U.S.G. § 1406(a) (1976), "The district court of a district in which is filed a case laying venue in the wrong division or district shall dismiss, or if it be in the interest of justice, transfer such case to any district or division in which it could have been brought."

91 See 15 Wright \& Miller, supra note 7, § 3846, at 362.

92 See, e.g., Hite v. Norwegian Caribbean Lines, 551 F. Supp. 390 (E.D. Mich. 1982) (case transferred back and forth between Eastern and Western Districts of Michigan) and cases therein cited, id. at 396; Rixner v. White, 417 F. Supp. 995, 998 (D.N.D. 1976) (case transferred from E.D. Mo. to North Dakota and then to Minnesota); Inductotherm Corp. v. Pillar Corp., 417 F. Supp. 991, 994 (E.D.Pa. 1976) (transfer to New Jersey does not preclude defendant from there renewing its motion to transfer to Wisconsin). On occasion, transferee courts have transferred cases back from whence they came. See, e.g., Brimer v. Levi, 555 F.2d 656, 658 (8th Cir. 1977) (where transferee district court dismissed for improper venue, appellate court held that case should have been transferred back to the transferor court); Holzsager v. Valley Hosp., 482 F. Supp. 629, 630 (S.D.N.Y. 1979) (transferee court, lacking federal subject matter jurisdiction, transferred case back to transferor court, suggesting remand to state court from which case had been removed).

98 The conclusion that cases rarely move on to a second or third transferee court is drawn by inference from the fact that one finds few cases involving second transfers or transfers back. 
the case, ${ }^{94}$ personal jurisdiction over the parties, ${ }^{95}$ and was a proper venue. ${ }^{96}$ Let us assume further that the ruling, reconsideration of which is sought after transfer, was on an issue of federal law. Faced with this situation, the transferee court could see its task as the relatively simple one of deciding whether to invoke law of the case doctrine by applying the rules, principles, and policies discussed earlier. ${ }^{97}$ Before reaching issues related to the substance or content of the doctrine, however, the transferee court would have to resolve a threshold question raised by the variations of law of the case doctrine among the federal courts. ${ }^{98}$ If the transferee court and the transferor court interpret the pertinent federal law of law of the case differently, and the two conflict as applied to the problem at hand, what body of law applies?

\section{a. Resolving Choice of Law Issues}

In cases where it was argued to a section 1404 transferee court that a ruling of the transferor court should be treated as law of the case, litigants and judges rarely have considered which circuit's version of the doctrine should apply. Insofar as the cases evince concern about whether the transferor court intended its determination to be binding upon the transferee court, they do suggest that the transferor court's version of the doctrine should apply. In Devex Corp. v. General Motors Corp. ${ }^{90}$ for example, the district court in Delaware was faced with plaintiff's motion for summary judgment in a patent case transferred from the Northern District of Illinois, after a full trial and appellate reversal. Plaintiff contended that the validity of the patent had been established by the decision of the Court of Appeals for the Seventh Circuit. Defendant General Motors (GM) argued that the patent's validity had not been determined because the Illinois district court's judgment was ineffective, for lack of proper venue. After holding that GM had waived its venue defense, the court looked to the words and actions of the transferor district judge to divine whether he intended the issue of patent validity to be reconsidered. In his transfer order, his comments from the bench, and his denial of a motion to strike that part of his judgment order holding the patent valid, the transferor judge evinced

24 Such jurisdiction is delineated in 28 U.S.C. $\$ 1331$ (1982).

${ }^{98}$ See Fed. R. Giv. P. 4(d), (e), (f).

of "A civil action wherein jurisdiction is not founded solely on diversity of citizenship may be brought only in the judicial district where all defendants reside, or in which the claim arose, except as otherwise provided by law." 28 U.S.C. § 1391(b) (1982).

97 See supra notes 67-89 and accompanying text.

${ }^{28}$ See supra notes 56-66 and accompanying text.

90 263 F. Supp. 17 (D. Del. 1967). 
his expectation that the transferee court would accept the patent validity determination as law of the case. The Delaware transferee court also stated that it took the case in the same posture as if it had not been transferred. Accordingly, because the validity determination of the Seventh Circuit bound the Illinois district court, the Delaware court was "similarly bound." 100 Both the Delaware court's interest in the intentions of the transferor court as to the effect of the patent validity determination and its willingness to be bound by the Seventh Circuit's ruling just as the transferor court was bound, are consistent with, and support use of, the transferor court's law of the case doctrine. ${ }^{101}$

Additional guidance on the applicability of the transferor court's law of the case doctrine comes from principles governing choice of law generally in transferred cases. The prevailing view has been that when a case is transferred under section 1404 the trial court should apply the law, more specifically, the substantive law, of the transferor court. ${ }^{102}$ This limitation apparently derives from an extension into federal question cases of a United States Supreme Court holding in a diversity case, Van Dusen v. Barrack, ${ }^{103}$ where the Court concluded,

[I]n cases . . . where the defendants seek transfer, the transferee district court must be obligated to apply the state law that would have been applied if there had been no change of venue. A change of venue under section 1404(a) generally should be, with respect to state law, but a change of courtrooms. ${ }^{104}$

$100 \mathrm{Id}$. at 24. Although the case was purportedly transferred under 28 U.S.G. $\S 1406$, it is appropriate to cite the case in this section of the Article concerning $\S 1404$ transfers because the Delaware transferee court treated the transfer as having been under $\S 1404$ by virtue of GM's having waived its venue objections. Id. at 23 .

102 Accord General Tire \& Rubber Co. v. Firestone Tire \& Rubber Co., 349 F. Supp. 333, 337 (N.D. Ohio 1972) (transferor court's findings could be reexamined when transferee court concluded that it was intended that case be transferred "unbound by prior determinations"), appeal dismissed, 431 F.2d 1199 (6th Cir. 1970), cert. denied, 401 U.S. 975 (1971).

102 See, e.g., Gonzalez v. Volvo of Am. Corp., 734 F.2d 1221, 1223 (7th Cir. 1984), substituted opinion, 752 F.2d 295 (7th Cir. 1985); Linnell v. Sloan, 636 F.2d 65, 66 (4th Cir. 1980); Schreiber v. Allis-Chalmers Corp., 611 F.2d 790, 793 (10th Cir. 1979).

108376 U.S. 612 (1964).

104 Id. at 639. When it is plaintiffs who seek transfer under $\S 1404$, some courts hold that the transferee district court may apply its own substantive law. See, e.g., O'Brien v. Lake Geneva Sugar Shack, Inc., 585 F. Supp 273 (N.D. Ill. 1984); Les Schwimley Motors, Inc. v. Chrysler Motors Corp., 270 F. Supp 418 (E.D. Cal. 1967); accord ALI, Study of the Division of Jurisdiction between State and Federal Courts, 155 (1969) (commentary on $\S 1306$ (c) states in part, "when the plaintiff . . . is seeking a transfer, he ought not to carry with him the choice-of-law advantage resulting from his initial choice of forum, even if that choice was made without full knowledge of the facts."). According to a major treatise, however, the courts increasingly are applying the 
Consistent with the Erie Railroad v. Tompkins ${ }^{105}$ doctrine on which the decision was partly predicated, the Court added, "Of course the transferee District Court may apply its own rules governing the conduct and dispatch of cases in its court [that is, its own procedural rules]. We are only concerned here with those state laws of the transferor State which would significantly affect the outcome of the case."108

From the proposition that federal courts having diversity jurisdiction over transferred cases may use their own procedural rules, it seems to follow a fortiori that federal courts having federal question jurisdiction over transferred cases also may use their own procedural rules. ${ }^{107}$ Yet, if this is so, then courts will have to decide whether law of the case doctrine is substantive or procedural in order to decide whether a section 1404 transferee court should apply its own version of law of the case. Because the courts have failed to recognize that law of the case doctrine differs among the circuits or that transferred cases present a threshold choice of law issue as to the doctrine, existing case law is virtually silent on this question. ${ }^{108}$

law of the transferor court, after $\S 1404$ transfers, regardless of which party moved for transfer. 15 WRIGHT \& MILLER, supra note 7, § 3486, at 367.

${ }^{108}$ Erie R.R. v. Tompkins, 304 U.S. 64 (1938). The Erie line of cases has spawned considerable scholarly writing. For an introduction, see FRIEDENTHAL, supra note $8, \S \S 4.1-4.6$, at 190-222. The better known recent articles include Ely, The Irrepressible Myth of Erie, 87 HaRv. L. REv. 693 (1974); Chayes, The Bead Game, 87 Harv. L. Rev. 741 (1974); Ely, The Necklace, 87 Harv. L. Rev. 753 (1974); Mishkin, Some Further Last Words on Erie-The Thread, 87 HARv. L. REv. 1682 (1974).

${ }_{108}$ Van Dusen, 376 U.S. at 639 n.40.

107 Neither the constitutional nor the statutory requirements underlying federal court application of state law, see infra text accompanying note 111, apply to federal issues within the federal question jurisdiction of the federal courts. Under Article III the federal courts, as an independent system for the administration of justice, are free to create their own rules of procedure for the adjudication of federal questions. See, e.g., Decker v. Massey-Ferguson Ltd., 29 Fed. R. Serv. 2d 239, 240 n.2 (S.D.N.Y. 1979) (transferee circuit's interpretation of federal civil procedure Rule 9(b), requiring particularity in pleading fraud, was applicable in federal securities fraud action). It is difficult to imagine that a transferee district court could not apply its own local procedural rules. However, an extreme acquired rights approach would carry forward even the transferor court's interpretations of the Federal Rules of Civil Procedure, its local rules and its approach to other procedural issues. See Marcus, Conflicts Among Circuits and Transfers with the Federal Judicial System, 93 YALE L.J. 677, 715 n.222 (1984). "Substantive" state law does, of course, govern state law claims in federal court under pendent or ancillary jurisdiction.

${ }^{108}$ In Barrett v. Baylor, 457 F.2d 119, 123-24 (7th Cir. 1972), the court did recognize the question, but found it unnecessary to answer because it assumed that all law of the case doctrine was the same:

Whether the application of the rule of the law of the case is a matter of procedure requiring application of the federal rule or a matter of substance requiring application of the state rule under the Rules of Decision Act . . . is not material in this case since the Illinois courts also apply the 
The federal courts cannot decide whether law of the case principles are substantive or procedural without developing a standard for the task. The Supreme Court has cautioned against borrowing the test for distinguishing substance from procedure employed in one context for use in another. ${ }^{100}$ It is nonetheless tempting to consider whether federal courts hearing diversity cases have held themselves bound by the law of the case doctrine of the respective states in which they sit-and there are reasons to yield to the temptation. It is true that some of the policies underlying the Erie line of cases are wholly inapplicable to the problem at hand. Erie was predicated in part on a concern that federal common law was being made in matters beyond those constitutionally delegated to the United States, ${ }^{110}$ whereas there can be no question that there generally is constitutional authority to make both procedural and substantive law as to the matters within the federal courts' original jurisdiction under section $1331 .^{111}$

The Erie court was also concerned, however, with eliminating a plaintiff's incentive to sue in federal court in order to obtain the benefits of a body of law more favorable than that which would govern in state court. ${ }^{112}$ Diversity jurisdiction was not intended to afford such an advantage; it was, as the Court found, conferred "in order to prevent apprehended discrimination in state courts against those not citizens of the state."113 It is similarly desirable to eliminate litigants' incentive to seek transfer in order to benefit from a body of law more favorable than that which would govern in the transferor court. ${ }^{114}$ Transfer is not

rule of the law of the case.

Professor Marcus observes that drawing the line between matters of substance and procedure can be difficult and that at present there is nothing to help lower federal courts resolve these questions. Marcus, supra note 107, at 715-16.

109 See Guaranty Trust Co. v. York, 326 U.S. 99, 108 (1945) (" "[S]ubstance' and 'procedure' are the same keywords to very different problems. Neither 'substance' nor 'procedure' represents the same invariants. Each implies different variables depending upon the particular problem for which it is used.")

110 Erie R.R. v. Tompkins, 304 U.S. 64, 78 (1938).

111 See, e.g., American Well Works v. Layne \& Bowler Co., 241 U.S. 257, 260 (1916) (a suit "arises under" the law that creates the cause of action).

112 See, e.g., Guaranty Trust Co., 326 U.S. at 109 ("the intent of [Erie] was to insure that . . . the outcome of the litigation in the federal court should be substantially the same, so far as legal rules determine the outcome of litigation, as it would be if tried in a State court.").

113 Erie, 304 U.S. at 74. Alternative explanations of the historic basis of diversity jurisdiction have been offered. See FRIEDENTHAL, supra note 8, § 2.5, at 25 .

114 Van Dusen v. Barrack, 376 U.S. 612, 630-37 (1964). The Court's conclusion that the transferee court should apply the law of the state in which the suit was commenced was based in large part upon its conclusion that $\S 1404$ was not designed to allow defendants to defeat the state-law advantages accruing from the plaintiff's choice of venue. It recognized that "[i]f a change of law were in the offing, the parties might well regard the section primarily as a forum-shopping instrument." Id. at 636. 
meant to afford such an advantage; it is intended to permit a suit to be tried in a proper forum that is more convenient for the parties and witnesses than the forum chosen by the plaintiff, if the transfer will serve the interests of justice. ${ }^{118}$ To the extent that a goal in both the Erie and the transfer contexts is the elimination of unintended advantages in governing law that spring from the choice of court, the line drawn between substance and procedure in Erie cases is relevant to how much of the transferor court's law should accompany a transferred case. ${ }^{118}$

The 1939 decision of the United States Supreme Court in Wichita Royalty Co. v. City National Bank ${ }^{117}$ supports the proposition that Erie requires federal diversity courts to follow state law of the case. In that litigation, the Supreme Court of Texas had reversed and remanded for a new trial, after stating the applicable principles of law for the guidance of the trial court. After remand, the suit was removed to federal district court. On appeal of the final judgment entered by that court, the federal appellate court remanded, stating the principles of law it thought applicable. These principles, however, were at variance with those the Supreme Court of Texas previously had declared to be controlling. ${ }^{118}$ In its consideration of the matter, the Supreme Court of

Of course, the Erie court was concerned primarily with forum shopping by plaintiffs, whereas transfer is most often sought by defendants. However, this generalization exaggerates the difference between forum-shopping parties. Outcome determinative differences between state and federal law also gave defendants an incentive to remove cases to federal court when they happened to be diverse from plaintiffs and general federal common law favored their position. Section 1404(a) transfer may be sought by plaintiffs. Thus, the Erie doctrine and the Van Dusen rule both seek to prevent any litigant from selecting or seeking to change the initial choice of forum in order to change the governing law.

${ }_{115}$ See Van Dusen, 376 U.S. at 635 (§ 1404(a) was designed simply to counteract the inconveniences that flow from broad venue provisions); Continental Grain Co. v. Barge FBL-585, 364 U.S. 19, 26-27 (1960) (the purpose of $\S 1404(a)$ is to prevent wasted time, energy, and money, and to protect litigants, witnesses, and the public against unnecessary inconvenience and expense).

116 Professor Marcus argues that the Erie concern of deterring forum shopping seems to have little relevance in Van Dusen, because any rule promotes one type of forum shopping and prevents another. See Marcus, supra note 107, at 694 n.115. But the Supreme Court does not regard all instances of forum-shopping as equal. Plaintiffs have a limited forum-shopping privilege, conferred by the venue statutes; defendants' efforts to forum-shop by seeking transfer is a tactic to be guarded against. See Van Dusen, 376 U.S. at 633-36. This Article agrees with Professor Marcus, however, that the Erie policy of eliminating the inequitable administration of the laws that results when some litigants can gain admission to federal court on the basis of diversity while others are confined to state court by the accident of their residence does not apply to the choice of law questions presented by the transfer of federal question cases between federal courts. See Marcus, supra note 107, at 695-96.

117306 U.S. 103 (1939).

118 Id. at 105-06. 
the United States said,

In departing from the "law of the case," as announced by the state court, . . . the court below correctly stated that ... it was its duty to apply the Texas law as the Texas court would have declared and applied it on the second appeal if the cause had not been removed. . . . [S]ince the Supreme Court of Texas holds itself free upon reconsideration to modify or recede from its own opinions, ... the court below, in applying the local law, was likewise free to depart from the earlier rulings to the extent that examination of the later opinion of the Texas Supreme Court showed that it had modified its opinion on the first appeal. ${ }^{119}$

Because the state court had not altered its opinion, however, that opinion had to be accepted as stating the law of Texas. ${ }^{120}$

Unfortunately, more recent case law has paid scant attention to whether a federal court sitting in diversity should be bound by the law of the case doctrine of the state in which it sits. The absence of commentary on the question must logically flow from one of two assumptions: that law of the case doctrine is always identical in a federal court and in the courts of the state in which it sits (hence no choice of law need be made), or that it is so clearly "procedural" that articulated analysis is superfluous. The former assumption is unlikely to be true. ${ }^{121}$ As for the second, although law of the case doctrine usually may be considered "procedural" for Erie purposes, this is not so clear in every case that explanation and analysis never are warranted. Law of the case is not an integral part of any special relationship between the parties, created by state law, ${ }^{122}$ nor would the choice of law of the

119 Id. at 107.

120 Id. at 110.

121 Writing twenty years ago, Professor Vestal found that

"Law of the case," in its various facets, varies from state to state and within a jurisdiction it is frequently in a condition of flux. At one extreme, the concept of "law of the case" has been abolished for the Supreme Court of Alabama by a statute. . . . On the other hand, some states purportedly adhere to the doctrine of "law of the case" with a rigidity approximating res judicata/preclusion by judgment . . . In the state of Iowa, "law of the case" is given binding effect when it is a question of an appellate court binding itself while "law of the case" is given no effect when it is a question of a trial court judge establishing a rule for later trial proceedings.

Vestal, supra note 7, at 2-4 (footnotes omitted). There is no particular reason to believe that the interstate variations in law of the case doctrine have evaporated since Professor Vestal wrote. Certainly, the law of the case doctrine in any particular federal court may vary substantially from that of the state in which it sits.

122 This test to determine the meaning of 'substantive' derives from Byrd v. Blue 
case rule substantially affect those primary decisions respecting human conduct that our constitutional system leaves to state regulation. ${ }^{123}$ The proper characterization of the doctrine is not self-evident, however, when the application of law of the case doctrine of a particular state depends on whether it

would make so important a difference to the character or result of the litigation that failure to enforce it would unfairly discriminate against citizens of the forum State, or ... would have so important an effect upon the fortunes of one or both of the litigants that failure to enforce it would be likely to cause a plaintiff to choose the federal court. ${ }^{124}$

At the extremes of state law abandonment of law of the case doctrine and federal doctrine stringency (or vice versa), these tests may mandate the use of state law, unless countervailing federal policies nonetheless justify the use of federal law. ${ }^{125}$

A court in search of guidance on the question of whether law of the case doctrine should be considered substantive or procedural might also look to the related question of whether the Rules of Decision Act ${ }^{126}$ compels a federal diversity court to employ the res judicata and collateral estoppel doctrines of the state in which it sits. Upon examination, however, one discovers a particularly bewildering area of the law. The resolution of the issue varies, depending upon whether a state or federal court entered the judgment in question and on whether the judgment's preclusive effects are being argued to a federal court sitting in the very state whose courts entered the judgment. ${ }^{122}$ No easy or uniform answer exists as to whether res judicata and collateral estoppel are "substantive" for purposes of the Erie doctrine. Even in the situation most similar to that presented by law of the case issues posed after a transfer, that is, where two federal courts having diversity jurisdiction

Ridge Rural Elec. Coop., 356 U.S. 525, 536 (1958).

123 See Hanna v. Plumer, 380 U.S. 460, 475 (1965) (Harlan, J. concurring).

124 Id. at 468 , n.9.

125 See Byrd, 356 U.S. at 537. Professor Vestal agreed:

Since a strict application of the "law of the case" might well change the outcome of litigation by applying an incorrect view of the law, it might be urged that Erie . . . controls, and that the federal courts would be forced to follow the state practice on such matters in non-federal cases. . . . Surprisingly enough, the federal courts generally do not refer to the law of the state in which they are sitting in "law of the case" problems. These seem to be treated as questions of judicial administration outside the scope of Erie.

Vestal, supra note 7, at 21-22.

12628 U.S.C. § 1652 (1982).

12718 WRIGHT \& MilleR, supra note $7, \S 4472$, at 726. 
are involved, the cases conflict and the law is not free from doubt. ${ }^{128}$

The argument can be made that res judicata principles support the conclusion that law of the case rules are procedural rather than substantive. The cases on res judicata suggest that the basic rules of claim and issue preclusion are determined by federal rather than state law. ${ }^{129}$ As to aspects of preclusion doctrine that reflect "substantive" policies, however, most notably the rules determining which non-parties will be bound by a judgment, the authorities favor adoption of state law by the federal courts. ${ }^{130}$ As a rather rough generalization then, res judicata and collateral estoppel doctrine-and, by inference, law of the case doctrine-would be treated as procedural under Erie when successive federal diversity courts are involved. This suggests that law of the case doctrine should be procedural for Van Dusen transfer purposes as well. A transferee court could apply its own law of the case doctrine rather than a different version of the doctrine utilized in the transferor court. If this is true for federal courts sitting in diversity, it should hold true for federal courts hearing federal question cases as well.

128 Compare, e.g., Hunt v. Liberty Lobby, Inc., 707 F.2d 1493, 1496 (D.C. Cir. 1983) (federal rules of res judicata determine the effect to be given a judgment by another federal court exercising diversity jurisdiction, when the question arose in another federal diversity case; even if the policy of uniform enforcement of state-created rights and obligations were implicated, the independent federal system for administering justice furnished affirmative countervailing considerations) and Precision Air Parts, Inc. v. Avco Corp., 736 F.2d 1499, 1503 (11th Cir. 1984) (federal common law applies when examining res judicata or collateral estoppel effects, regardless of whether the prior federal judgment was based on diversity or federal question), cert. denied, 469 U.S. 1191 (1985) and Wehling v. Columbia Broadcasting System, 721 F.2d 506, 508 (5th Cir. 1983) (applying federal law in examining collateral estoppel effect of prior federal judgment) and Kern v. Hettinger, 303 F.2d 333, 340 (2d Cir. 1962) (it would be strange doctrine to allow a state to nullify the judgments of federal courts constitutionally established and given power to enforce state created rights) (dictum) with McDonald v. Johnson \& Johnson, 776 F.2d 767, 569-70 (8th Cir. 1985) (res judicata is an issue of substantive law requiring application of state law in diversity actions) and Answering Serv., Inc. v. Egan, 728 F.2d 1500, 1505-06 (D.C. Cir. 1984) (in sequential diversity cases, Erie requires the use of those aspects of res judicata and preclusion law that are substantive; "[b]roader language in Hunt could be taken out of context to support the view that federal res judicata rules always govern in diversity.") and Semler v. Psychiatric Inst., 575 F.2d 922, 927-28 (D.C. Cir. 1978) (state res judicata rules govern in diversity actions in the absence of an overriding federal interest) and Murphy v. Landsburg, 490 F.2d 319, 323 (3d Cir. 1973) (applying state collateral estoppel rules in diversity cases), cert. denied, 416 U.S. 939 (1974).

139 See Restatement (Second) of Judgments $\S 87$ (1982) Comment b and Reporter's Note to Comment b, and cases therein cited; Degnan, Federalized Res Judicata, 85 YALE L.J. 741, 764-73 (1976). See generally, 18 WRIGHT \& MiLlER, § 4472, at 735-38, and cases therein cited (1981).

130 See Restatement (Second) of Judgments $§ 87$ (1982) Comment b and Reporter's Note to Comment b; 18 Wright \& MilleR, § 4472, at 733-34 (1981). Where law of the case is involved, there should be no question as to who is bound, absent joinder of parties subsequent to the ruling in question. 
This last conclusion is the same as that arrived at by Professor Richard Marcus, who approached the problem differently. Professor Marcus recently argued that when federal claims are transferred, the principle that the transferee federal court is competent to decide federal issues indicates that the transferee court's interpretation of substantive, as well as of procedural, law should apply. ${ }^{131}$ In any circuit adopting Professor Marcus' view and its apparent implications, the transferee judge's decision as to whether and how to apply law of the case, as well as her other rulings on federal issues, will be made and reviewed under the interpretations of federal law controlling in the transferee circuit, regardless of whether law of the case is considered substantive or procedural.

Certain policy considerations also support an approach that allows a transferee court to apply its own law of the case principles. After all, a transferee court's use of its own law simplifies matters and increases the probability that the law will be correctly perceived and applied. In addition, the transferee court's interest in the use of its time is arguably grounds for application of that court's own preclusion law. There are, however, persuasive reasons to hold to the contrary. A principled choice of law doctrine arguably points to selection of the law of the transferor court and provides a theoretical basis for concluding that the plaintiff, by exercising the venue privilege, acquires the right to have the transferor court's law of the case doctrine apply. This argument, which follows, is based on the assumption that law of the case should be treated, for present purposes, in the same way that its "relations," res judicata and collateral estoppel, are treated.

131 In brief, Marcus argues that Van Dusen's principles are inapplicable to transfers of federal claims. After pointing out that Erie is limited to issues of state law, he argues that two of Erie's concerns pertaining to the transfer situation and supportive of Van Dusen, unfair discrimination against parties ineligible to enter federal court on the basis of diversity and protection of state policy, are irrelevant to federal question cases. See Marcus, supra note 107, at 693-96. Marcus also argues that there is no theoretical basis for concluding that a plaintiff acquires the right to have a certain state's law apply by exercising the venue privilege: "[i]dentifying the convenient or fair location for a suit . . . has no inherent connection to selecting the source of law that should govern the case." Id. at 697-98. Citing in support Piper Aircraft Co. v. Reyno, 454 U.S. 235 (1981), and its distinction of Van Dusen, Marcus concludes that choice of law has "followed' venue because no different or more principled choice of law doctrine has evolved for diversity cases. Id. at 700-01.

By contrast, Marcus finds that in federal question cases and as to federal issues generally, the principle that federal courts are presumptively competent to decide issues of federal law mandates that they make the decisions they believe to be correct, instead of following the interpretation of another circuit by rote. This principle applies as forcefully in transferred cases as in all others. Id. at 701-09. Marcus finds that neither the legislative history nor the policy of the transfer statute, 28 U.S.C. $\S 1404$, provides a reason for altering this conclusion. $I d$. at $702,709-16$. 
Neither the full faith and credit clause of the United States Constitution ${ }^{\mathbf{1 3 2}}$ nor the full faith and credit principle embodied in the federal code ${ }^{133}$ requires federal courts to treat the judgments of other federal courts with the same respect that those judgments would receive in the court rendering judgment. ${ }^{134}$ It is well established by case law, however, that federal law controls the res judicata effects of a federal court decision on a federal question in subsequent federal court litigation. ${ }^{135}$ Because federal courts have tended to assume that there is a federal law of res judicata and collateral estoppel, uniform in all its particulars, they have not focused upon "whose" federal law of preclusion should be applied. By analogy to cases decided under the full faith and credit principle, however, under federal law the second court would have to look to the judgment-rendering court's version of preclusion law to determine the precise res judicata and collateral estoppel effects of the judgment. ${ }^{136}$ Because law of the case doctrine is a member of the

132 "Full Faith and Credit shall be given in each State to the public Acts, Records, and judicial Proceedings of every other State." U.S. CoNST. art. IV, $\S 1$.

13828 U.S.C. § 1738 (1982) states, in pertinent part, that "[s]uch . . . Acts, records and judicial proceedings or copies thereof [of any court of any State, Territory or Possession of the United States], so authenticated [as prescribed in the preceding paragraph], shall have the same full faith and credit in every court within the United States and its Territories and Possessions as they have by law or usage in the courts of such State, Territory or Possession from which they are taken."

1st The full faith and credit clause of the Constitution applies only to state courts. See Baldwin v. Iowa State Traveling Men's Ass'n, 283 U.S. 522, 524 (1931). Section 1738 gives state judicial proceedings the same effect in federal courts as they have in their home state courts. See Davis v. Davis, 305 U.S. 32, 40 (1938).

135 18 WrIGHT \& MILLER, supra note 7, § 4466, at 618 and 618-20 nn.7-9 (1981) (citing cases and commentators); see also RESTATEMENT (SECOND) OF JUDGMENTS $\S 87$ (1982) ("Federal law determines the effects under the rules of res judicata of a judgment of a federal court.").

1se See Stoll v. Gottlieb, 305 U.S. 165 (1938) (when a federal court judgment is asserted in a state court action, the state court must look to the judgment rendering court's law to determine all questions of binding effect); Crescent City Live Stock Co. v. Butchers' Union Slaughter House Co., 120 U.S. 141, 157 (1887) (having jurisdiction of the parties and of the subject matter of the suit, the federal judges were bound to declare the law of the case, and its effect is binding between those parties in the state supreme court); Embry v. Palmer, 107 U.S. 3 (1882) (the rendering court's judgment is to be given the same effect elsewhere as in its own jurisdiction). See Degnan, supra note 129, at 768 ("Federal judgments should be given the 'same full faith and credit in every court . . . as they have by law or usage' in the court of rendition." (quoting 28 U.S.C. § 1738 (1970)). Degnan argues that the constitutional power of federal courts to decide cases and controversies implies some binding effect, and that it is in the nature of the judicial power to determine its own boundaries. Id. at 768-69. But see 28 U.S.C. $\S 1963$ (1982), giving federal judgments registered in other districts "the same effect as a judgment of the district court of the district where registered." As noted in Vestal, Res Judicata/Preclusion by Judgment: The Law Applied in the Federal Courts, 66 Mich. L. REv. 1723, 1744 n.80 (1968), instead of giving judgments the effect that would be given in the state of rendition, this provision equates foreign federal court judgments with judgments rendered by the local federal court. 
same legal family as res judicata and collateral estoppel, and is based on the same root concerns, ${ }^{137}$ it makes sense for a later involved court similarly to look to the law of the case doctrine of the earlier ruling court to determine the preclusive effect to be ascribed to a ruling. Thus, a transferee court would apply the law of the case doctrine of the transferor court, where it differed from that of the transferee court. The appellate court would face the same task, reviewing the transferee judge's decision as to law of the case under the interpretations of federal law controlling in the circuit embracing the transferor court. This conclusion is in line with the general trend of the law: that preclusion questions will be governed by the law of the court that entered the judgment. ${ }^{138}$

It must be conceded that this argument may falter. The assumption that law of the case should be treated like res judicata and collateral estoppel is open to challenge, as is the analogy to full faith and credit principles. ${ }^{\mathbf{1 3 9}}$ Moreover, well-respected authorities have argued that aspects of preclusion doctrine that are incidental to its central role and that may intrude on substantial interests of later courts should fall outside the dictates of full faith and credit, even where it is applicable, and that other courts should be free to reject such excluded aspects, in the exercise of the great freedom that exists in choice of law generally. ${ }^{140}$ Given the absence of a final judgment and the discretionary nature of the doctrine, law of the case could be treated as such an "inci-

137 See supra notes 8-9 and accompanying text.

13818 WRIGHT \& MilleR, supra note $7, \S 4472$, at 735-38.

139 See Allstate Ins. Co. v. Hague, 449 U.S. 302, 307-13 (1981) (plurality opinion) (Justice Brennan remarked upon the substantial differences between the full faith and credit tests and the tests that provide minimal limits on choice of law in other settings); Williams v. Ocean Transp. Lines, Inc., 425 F.2d 1183, 1188-89 (3d Cir. 1970) (whether state law should control the collateral estoppel effects of a federal diversity judgment in a later federal question case depends on whether collateral estoppel rests on the same policies as full faith and credit, in which case law of the first forum applies, or on a policy of preserving courts from onerous relitigation, in which instance the second court should consult its own preclusion law).

14018 WRIGHT \& MILLER, supra note $7, \S 4467$, at 636-48. The treatise argues, for example, that full faith and credit should not require a court to preclude relitigation of questions that were the basis of different ultimate issues in prior litigation, when the court ordinarily would refuse to preclude such relitigation. Id. at 641-42. It argues that non-mutual preclusion should not be mandated by full faith and credit, id. at $642-43$, and in particular, that

[s]ome courts are willing to rest issue preclusion on interlocutory determinations that remain open to alteration even in the trial court. More conservative courts should be free to litigate the same issues-here, if nowhere else, it seems clear that there is not yet any judgment, and the vague full faith and credit terminology of "judicial proceedings" should not be expanded beyond judgments at this late date.

Id. at 643 (footnote omitted). 
dental aspect" of preclusion doctrine and left to the law of a transferee court.

For the reasons previously set forth ${ }^{141}$ however, the familial relationship between law of the case and collateral estoppel argues strongly in favor of the courts' affording them parallel treatment. Requiring a transferee court to afford the same law of the case effects to an interlocutory ruling as the ruling would have in the rendering court is consistent with the movement of the law and the full faith and credit concept. ${ }^{122}$ Greater liberality in reconsideration may encourage forum shopping; increased tightfistedness gives a ruling more permanence than it was intended to have. The problem cannot be dismissed by invoking the discretionary nature of the doctrine because the choice of law dilemma is posed only when a conflict exists between the competing doctrines, as applied. Furthermore, no strong reasons exist for a transferee court to use its own law of the case doctrine when its doctrine conflicts with that prevailing in the court ruling earlier. The burden of ascertaining and applying "foreign" law is avoided, but that small gain seems to be the only major advantage of a transferee court applying its own doctrine. Consequently, the better rule in such circumstances is for the transferee court to apply the law. of the case doctrine of the transferor court.

The transfer statute ${ }^{\mathbf{1 4 3}}$ does not require a different result. Nothing in the language of section 1404 addresses the question. Professor Marcus's recent study of section 1404(a) led him to conclude that its legislative history says little about choice of law and that the drafters may never have considered which forum's law should apply to transferred cases. ${ }^{144}$ There certainly is no suggestion that the drafters considered the particular problem of which forum's law of the case doctrine should apply to transferred cases. It is true that the burden on transferee courts is increased if and when the transferor court's unfamiliar law of the case doctrine must be applied: such application carries the attendant problems of ascertaining the nuances of that law. Van Dusen makes clear, however, that section 1404 transferee courts often must apply law other than their own. The imposition of a burden, particularly an insubstantial one, is not by itself a reason to conclude that section 1404 requires a different result.

The discussion to this point has assumed that the transferor court had federal question subject matter jurisdiction over the case, personal

\footnotetext{
141 See supra notes $132-38$ and accompanying text.

${ }^{142}$ See supra notes $132-38$ and accompanying text.

14328 U.S.C. § 1404 (1982).

144 See Marcus, supra note 107 , at 710 n.198.
} 
jurisdiction over the parties, was a proper venue, and that the ruling being challenged after transfer was on an issue of federal law. ${ }^{145}$ Suppose, however, that the transferor court's jurisdiction was based on diversity of the parties rather than on authority to adjudicate federal question cases. The change in the basis for the court's jurisdiction leads to some changes in the choice of law analysis.

When state law claims are involved by virtue of diversity jurisdiction, the earlier mentioned decision of the United States Supreme Court in Van Dusen v. Barrack ${ }^{\mathbf{1 4 8}}$ requires that the substantive law that would have been applied by the transferor court, under the conflicts of laws rules of the transferor state, will continue to apply after a section 1404(a) transfer on defendants' motion. ${ }^{147}$ As previously noted, case law is largely silent as to whether law of the case doctrine is substantive under Van Dusen and under Erie, ${ }^{\mathbf{1 4 8}}$ but on occasion it could be considered as such. By analogy to res judicata and collateral estoppel in sequential diversity actions, the trend is toward treating many aspects of preclusion doctrine as procedural and hence governed by a federal preclusion law. There is, however, a split of authority. ${ }^{149}$ In those circuits where res judicata and collateral estoppel are substantive, law of the case doctrine should be similarly categorized. A federal court, sitting in diversity, would then utilize the law of the case doctrine of its state's courts. If, as is likely, the characterization for Erie purposes carries over into section 1404 transfer situations, the result would be that transferee courts would use the law of the case doctrine of the state in which the transferor court sits, when reconsideration was sought of a ruling by the transferor court. This result seems appropriate because the law of the case doctrine of the transferee state may be very different from the doctrine in the transferor state and transfer should not alter applicable "substantive" law.

By contrast, in circuits where federal preclusion law governs in successive diversity suits, law of the case should be procedural. A transferee court would use its own doctrine ${ }^{160}$ unless a principled choice of law doctrine, other than Van Dusen, pointed to selection of the law that would be used by the transferor court. Again, as a matter of federal law of the case doctrine, such a principled basis can be found in an

14s See supra text accompanying notes 94-96.

146376 U.S. 612 (1964).

${ }_{147}$ See supra text accompanying notes 102-06.

148 See supra text accompanying notes 117-25.

149 See supra notes 126-30.

150 Professor Marcus's view that the transferee court is competent to decide and should decide federal issues in diversity cases is in accord. See Marcus, supra note 107, at 709 n.193. 
analogy to the full faith and credit due to judgments: the ruling court's law should determine the precise preclusive effects of its decisions.

\section{b. The Effects of Appellate Jurisdictional Limits and of the "Competence" Principle}

Once the court has resolved the choice of law issue, its next step is to apply the governing doctrine to the problem at hand. In this context, further complications can arise out of the transfer. The content or application of law of the case doctrine in transfer situations can be affected by perceptions concerning federal appellate jurisdiction and by whether the transferee circuit subscribes to the "competence" principle. ${ }^{181}$

Some federal courts have held that the appellate court for the transferee district has jurisdiction to review decisions rendered by transferor district courts in other appellate circuits. ${ }^{162}$ The "competence"

151 See infra text accompanying note 153.

182 See Astarte Shipping Co. v. Allied Steel \& Export Serv., 767 F.2d 86, 87 (5th Cir. 1985) (appellate court had jurisdiction over appeal of order permitting attachment of property, entered by Southern District for New York prior to $\S 1407$ transfer to Eastern District for Louisiana; requiring appeal to be taken to the Second Circuit Court of Appeals "would place the Second Circuit . . . in the position of affirming or reversing an order in a case under the sole jurisdiction of a district court in the Fifth Circuit."); In re Dalton, 733 F.2d 710, 717 (10th Cir. 1984) (debtor was not entitled to mandamus for review of bankruptcy court order transferring venue because of possibility of review on appeal from final judgment in the transferee circuit), cert. dismissed, 469 U.S. 1185 (1985); American Fidelity Fire Ins. Co. v. United States Dist. Ct., N.D. Cal., 538 F.2d 1371, 1377 n.4 (9th Cir. 1976) (on appeal from a final judgment, court could exercise its appellate jurisdiction to review a district court's transfer order even if the transferor court was not within its circuit); Magnetic Eng'g \& Mfg. Co. v. Dings Mfg. Co., 178 F.2d 866, 869-70 (2d Cir. 1950) (Second Circuit would not grant mandamus to vacate a $\S 1404$ transfer order of judge of Southern District for New York transferring case to Eastern District of Wisconsin, saying, "whatever power of review we may have, the Court of Appeals for the Seventh Circuit has the same . . . The review of any order of the district court in a transferred cause, made before transfer, is within the jurisdiction of the court of appeals of the circuit to which the cause has been transferred ... ."); $c f$. Nascone v. Spudnuts, Inc., 735 F.2d 763, 772 n.9 (3d Cir. 1984) (law of the case would not prevent a transferee circuit, on appeal from final judgment or mandamus, from in effect overruling the determination of the transferor district court as to venue).

Another interesting case is Meat Price Investigators Ass'n v. Spencer Foods, Inc., 572 F.2d 163, 164-67 (8th Cir. 1978), in which the Eighth Circuit, as the court of appeals for a $\S 1407$ transferor court, accepted the appeal of an order entered by the transferor court subsequent to the physical transfer of the original case papers. The order under scrutiny denied a motion to disqualify plaintiff's attorneys. The Eighth Circuit acquiesced in the assumption that appeal could also have properly been brought to the Fifth Circuit, as appellate court for the transferee court. Id. at 167 n.3. The Eighth Circuit noted, however, that the order concerned allegedly unethical conduct of attorneys in the Eighth Circuit, a matter of considerable concern to that court, and that its decision "on the merits" of the issue would not materially impede the progress of pretrial proceedings in Texas. Meat Price is out of step with the strong weight of 
principle, that federal courts are presumptively competent to decide issues of federal law, ${ }^{\mathbf{1 6 3}}$ suggests that transferor court decisions of issues of federal law will be reviewed under interpretations of federal law controlling in the transferee circuit. ${ }^{154}$ In this circumstance, the district

authority holding that a transferor court is without jurisdiction to enter further orders from the time of entry of the order of transfer. See Glasstech, Inc. v. AB Kyro OY, 769 F.2d 1574, 1576-77 (Fed. Cir. 1985) and cases therein cited. No appellate court has jurisdiction to decide the merits of an issue if the court from which the appeal was taken was without jurisdiction. Id. at 1577.

153 See Marcus, supra note 107, at 702.

154 Professor Marcus never expressly takes this position. However, it is consistent with what he does say and with his reading of Hoffman v. Blaski, 363 U.S. 335 (1960). First, Professor Marcus writes, "There is no room in the federal system of review for rote acceptance of the decision of a court outside the chain of direct review. If a federal court simply accepts the interpretation of another circuit without addressing the merits, it is not doing its job." Id. at 702. Relying on Hoffman as illustrative, he continues, "[T]his principle of competence applies as forcefully to a transferred case as to any other case involving an issue on which the circuits conflict. After transfer, the transferee court has the same right and duty to decide the transferred federal claim on its own as it has in every other case." Id. at 705. Finally, he states, "The assumption that each federal court is competent to decide federal questions is therefore inconsistent with preserving the selection of a given circuit's interpretation . . [ [T] $]$ he system abhors efforts to undermine the authority of the assigned court to decide the case correctly on the merits." Id. at 706-07.

In Hoffman, plaintiffs brought a patent infringement action in the Northern District of Texas. Over plaintiffs' objections, that court granted defendants' motion to transfer the case, under $\S 1404(\mathrm{a})$, to the Northern District of Illinois. The United States Court of Appeals for the Fifth Circuit then denied plaintiffs' motion for leave to file a petition for writ of mandamus directing vacation of the transfer order. Ex parte Blaski, 245 F.2d 737, 738 (5th Gir.), cert. denied, 355 U.S. 872 (1957). Plaintiffs next moved, in the transferee district court, for an order "remanding" the action, based on the same argument they had previously made: that the Northern District of Illinois was not a district where the suit "might have been brought" within the meaning of $\S 1404$ (a). Hoffman, 363 U.S. at 337. When the trial judge denied their motion, plaintiffs sought from the Seventh Circuit a writ of mandamus directing the trial judge to reverse his order. Id. at 338. The Seventh Circuit agreed with plaintiffs' reading of the transfer statute and granted the writ, saying: "[W]e think the decision of the Fifth Gircuit in this matter is erroneous. Such being the case, we are under no more obligation to follow it as the law of the case than that Circuit would be to follow what it considers an erroneous decision by this Court." Blaski v. Hoffman, 260 F.2d 317, 322 (7th Cir. 1958). The United States Supreme Court granted certiorari and then affirmed. Hoffman v. Blaski, 363 U.S. 335 (1960). Professor Marcus reads the case as making clear "that one circuit need not follow a decision of another circuit that it regards as erroneous." Marcus, supra note 107, at 704. If the Seventh Circuit was not bound to follow an actual decision by the Fifth Circuit in the same case, it would seem to follow a fortiori that it would not need to follow Fifth Gircuit law as elaborated in unrelated cases when judging the correctness of a ruling by a transferor district court within the Fifth Gircuit when that ruling came up on appeal from a judgment entered by a transferee district court within the Seventh Circuit's jurisdiction.

Hoffman v. Blaski does not support Professor Marcus's position as much as the foregoing discussion would suggest, however. In affirming the Seventh Circuit, the Supreme Court relied in part upon the fact that none of the parties contended that the order of the Fifth Circuit denying mandamus precluded the transferee district judge or the Seventh Circuit from "remanding" the case. 363 U.S. at 340. The Supreme Court 
judge asked to reconsider an initial ruling of the transferor court has two choices. She can decline to reach the merits of the underlying legal question, invoking law of the case for the sake of efficiency, stability, consistency, and "comity"-the values normally expected to prevail. Alternatively, she can, and indeed may have to, subordinate those values when reversal with all of its attendant inefficiencies would be probable if she failed to reconsider and perhaps to modify or "reverse" the initial ruling in light of the interpretation of federal law controlling in her circuit. This, of course, is a Hobson's choice: the latter alternative is the only sensible one. ${ }^{188}$

In transferee courts that apply the interpretations of substantive law that would have been applied by the transferor court, even on questions of federal law, ${ }^{186}$ this dilemma will not arise. ${ }^{187}$ Law of the

read the Fifth Circuit's order as one which "did not purport to determine the jurisdiction of the transferee court and therefore did not preclude Judge Hoffman of power to determine his own jurisdiction, nor did it preclude the power of the Seventh Circuit to review his action." Id. at 340 n.9. The Court may have been wrong in its reading of the Fifth Circuit's order. See id. at 345-48 (Frankfurter, J., dissenting). However, what is important is that in Hoffman the Court viewed the situation as one in which a transferee appellate court was not bound by law of the case as established by the coordinate transferor appellate court because the transferor circuit had not made law on the particular point in question. In that situation, the Seventh Circuit was reviewing a decision by the district court for the Northern District of Illinois; it was not reviewing the transfer order of the Texas district court. The Court quite naturally approved the transferee appellate court's application of its own interpretation of federal law, here, of $\S 1404(a)$. On this reading, the case does not furnish strong support for Professor Marcus's "principle of competence." The only acknowledgment Professor Marcus gives to the problem with his reading of Hoffman is the cryptic caution: "Whatever the merit of the Seventh Circuit's disregard of the law of the case, [citation to Justice Frankfurter's dissent] Hoffman . . . makes clear that one circuit need not follow a decision of another circuit that it regards as erroneous." Marcus, supra note 107, at 704.

${ }^{168}$ Accord 1B MOORE's Federal PRACTICE, supra note 7, II 0.404 [4.-2], at 129:

If the law of the transferee circuit is unsettled, and reconsideration will impede materially the progress of the case to final judgment, the advantages of continuity suggest that the court should follow the pretransfer decisions as law of the case and leave for another day, or to the court of appeals, the fashioning of a local rule. If the issue has been settled, however, the transferce court finds itself suspended between the doctrine of stare decisis and the doctrine of the law of the case. In such a circumstance the transferee court would invite reversal if it did not follow the decisions of its own court of appeals. In cases in which the transfer has been effected for the convenience of the witnesses and parties, this is not an altogether happy solution.

(footnotes omitted).

18s See, e.g., Berry Petroleum Co. v. Adams \& Peck, 518 F.2d 402, 408 n.7 (2d Cir. 1975) (applying transferor substantive law in SEC rule 10b-5 case); Sargent v. Genesco, Inc., 492 F.2d 750, 758 (5th Cir. 1974) (using transferor forum's state statute of limitations for 10(b)-5 suit); Sentner v. Amtrak, 540 F. Supp. 557, 559 n.5 (D.N.J. 1982) (applying substantive law of the transferor forum in deciding whether Amtrak is instrumentality of federal government). Additional cases are cited in Marcus, supra note 107 , at $692-93$ n.100. 
case doctrine can be applied as usual and, if the transferee court correctly invokes law of the case, then its appellate court will review the transferor court's ruling by reference to the interpretation of federal law controlling in the federal circuit embracing the transferor court. If the transferee court correctly reconsiders the previous ruling on its merits and hands down a superseding ruling, again the appellate court will review that latter ruling by reference to the transferor circuit's interpretation of federal law. In this way, a trial court facing the question whether to preclude reconsideration of an interlocutory order can apply law of the case principles without distortions arising from a preceding transfer, and an appellate court can maintain control over the decisions made by the district courts within its jurisdiction without purporting to correct the district courts outside its jurisdiction. ${ }^{158}$

In contrast with these circuits, other federal appellate courts have held that they lack jurisdiction to review decisions rendered by transferor district courts outside their respective circuits. ${ }^{159}$ This lack of ju-

157 Similarly, on issues of state law, the substantive law applied by the transferor court would continue to apply. Van Dusen v. Barrack, 376 U.S. 612 (1964); see also supra text accompanying notes 102-04. The dilemma posed in the text would not arise.

${ }^{158}$ One treatise states that "[a]s a practical matter, the issue of the law of the case after intercircuit transfer should almost never arise in connection with decisions of substantive law" because transfers tend to occur early in the proceedings. 1B MoorE's Federal Practice, supra note 7, II 0.404 [4.-2], at 130. However, transfers do not always occur early, see supra text accompanying note 99 , and law of the case problems can and do arise on questions of law as to which the circuits are in conflict. See, e.g., In re Burlington N., Inc., 679 F.2d 762 (8th Cir. 1982), discussed infra at notes 366-73, 379-80 and accompanying text. That case posed a law of the case problem for the $\S$ 1407 judge on the question whether to recognize a "critical self-analysis" privilege, a question over which the federal courts were split.

158 See Hatch v. Reliance Ins. Co., 758 F.2d 409, 413 (9th Cir. 1985) (where, prior to transfer, appellant sought mandamus from the transferor Fifth Circuit arguing improper removal and transfer, and petitioned for a writ of certiorari, reconsideration should not be afforded; there was no indication that appellants had not received a full and fair opportunity to litigate before the transferor court), cert. denied, $106 \mathrm{~S}$. Ct. 571 (1985); Roofing \& Sheet Metal Serv., Inc. v. La Quinta Motor Inns, Inc., 689 F.2d 982, 985-87 (11th Cir. 1982) (lack of jurisdiction to review transfer order issued by district court in another circuit); Linnell v. Sloan, 636 F.2d 65, 67 (4th Cir. 1980) (lack of jurisdiction to decide whether transfer was an abuse of discretion where plaintiffs failed to move for retransfer); General Elec. Co. v. Byrne, 611 F.2d 670 (7th Cir. 1979) (where a California district court remanded certain actions to state court after the JPMDL had stayed its conditional order transferring the actions to the Northern District for Illinois, the Seventh Circuit had no jurisdiction to issue a writ of mandamus to the California federal district court judge to prevent such remand); Technitrol, Inc. v. McManus, 405 F.2d 84, 87 (8th Cir. 1968) (court expressed "grave doubt" whether it had a right to review the validity of a transfer order made outside the circuit), cert. denied, 394 U.S. 997 (1969); Purex Corp. v. St. Louis Nat'l Stockyards Co., 374 F.2d 998, 999-1000 (7th Cir.) (absent motion to retransfer made in transferee district court, court of appeals in Seventh Circuit had no power to adjudicate allegedly erroneous transfer by district court in Eighth Circuit; plaintiff's remedy was resort to Eighth Gircuit), cert. denied, 389 U.S. 824 (1967); Preston Corp. v. Raese, 335 F.2d 
risdiction is believed to follow from 28 U.S.G. section 1294, which provides: "Appeals from reviewable decisions of district and territorial courts shall be taken to the courts of appeals as follows: (1) From a district court of the United States to the court of appeals for the circuit embracing the district." 160

What are the implications of this absence of appellate jurisdiction for a transferee district court asked to review a ruling of a transferor

827, 828 (4th Cir. 1964) (appeal of transfer order by district court outside circuit dismissed for lack of appellate jurisdiction); In re Southwestern Mobile Homes, Inc., 317 F.2d 65, 66 (5th Cir. 1963) (extremely doubtful that transferee appellate court had power to compel district judge for transferor district to vacate his $\S 1404$ transfer order); MacNeil Bros. v. Cohen, 264 F.2d 186, 187 (1st Cir. 1959) (per curiam) (case filed in Maryland had been transferred under $\S 1404$ to Massachusetts. Appellate court refused to transfer to another court of appeals to quell appellant's fear of prejudice, and questioned how another court would have statutory jurisdiction to review the district court's final decision). Other circuits have avoided addressing the question of such "extraterritoriality." See, e.g., Abels v. State Farm Fire \& Casualty Co., 770 F.2d 26, 28 n.2 (3d Cir. 1985) (plaintiffs offered no authority for the proposition that an appellate court could review the transfer determination of a district court outside the circuit; in view of the court's disposition of the subject matter jurisdiction issue, the court found it unnecessary to address the problem).

Orders granting or denying motions to transfer under $\S 1404$ or $\S 1406$ are interlocutory orders, not immediately appealable as of right. See, e.g., D'Ippolito v. American Oil Co., 401 F.2d 764 (2d Cir. 1968) ("It is hard to see how any order could be less 'final' than one which merely transfers an action for trial from one district to another in the federal judicial system whether the transferee district is in the same circuit or a different one."). Such orders can be reviewed on appeal from a final judgment if a case stays within the circuit where it commenced. After final judgment, some courts of appeal will also review transfer orders by district courts outside the circuit. See supra note 152 . There are two possible routes to immediate appellate review of $\S \S$ 1404 and 1406 transfer orders in or out of circuit: (a) 28 U.S.C. § 1292(b), which gives the federal appellate courts discretion to hear interlocutory appeals when the district judge certifies that the order involves a controlling question of law as to which there is substantial ground for difference of opinion and that immediate appeal may materially advance ultimate termination of the litigation; and (b) the extraordinary writs of mandamus and prohibition under the All Writs Statute, 28 U.S.G. $§ 1651$ (1982). Such appeals go to the appellate court embracing the transferor district court. See, e.g., Nascone v. Spudnuts, Inc., 735 F.2d 763, 765 (3d Cir. 1984) (if defendant successfully moved to transfer case out of circuit, plaintiff could ask the transferor court to certify the issue to that court's appellate body or could petition that appellate court for writ of mandamus); In re Dalton, 733 F.2d 710, 715 (10th Cir. 1984) (because transferor court did not allude to $\S 1292$ (b), if appellate court of transferor's forum had jurisdiction, it would lie exclusively in the issuance of an extraordinary writ), cert. dismissed, 469 U.S. 1185 (1985). For a review of the law arising out of such efforts to obtain reversal of transfer orders, and in particular of the conflicting attitudes of the various courts of appeals as to whether mandamus should issue when the trial court is alleged only to have abused its discretion, see 1 MOORE'S FEDERAL PRACTICE, supra note 7, II 0.147, at 1693-1712; 9 MOORE's Federal Practice, supra note 7, II 110.13[6], at 173-80; 15 Wright \& MilleR, supra note 7, § 3855.

10028 U.S.C. § 1294(1) (1982). As the Eleventh Circuit noted in the La Quinta case, $689 \mathrm{~F} .2 \mathrm{~d}$ at $986 \mathrm{n.5}, \S 1294(1)$ applies to all reviewable decisions of the district courts, not only to those that are immediately appealable. As to the distinction, see 9 MOORE's Federal PRACTICE, supra note 7, I 110.01, at 47. 
court in another circuit? If the transferee appellate court lacks jurisdiction to review such rulings, it would seem to follow that the transferee district court never can utilize the escape from law of the case doctrine grounded in the prior ruling being clearly erroneous. The clearly erroneous test functions to eliminate avoidable reversals, but in these circumstances no reversal of the transferor court's ruling is possible. In addition, it would seem highly anomalous for a transferee district court to undertake correction of the alleged errors of a transferor court when the higher court in the transferee circuit is not empowered to do so. The consequence of all this seems a most unappealing one: that clear errors stand, untouchable. The sole mitigating factor is that appellate review of transferor court rulings could have been sought prior to transfer under exceptions to the final judgment rule and via petitions for extraordinary writs such as mandamus. ${ }^{161}$

This set of consequences is unacceptable because of the difficulties that attend obtaining relief by such procedures, ${ }^{162}$ but it is avoidable. First, it must be recognized that the clearly erroneous exception to law of the case doctrine does more than protect against avoidable reversals; it is also intended to and does further the goal of doing justice for the litigants. ${ }^{168}$ If anything, therefore, a transferee district court should be more willing than usual to review transferor court holdings alleged to be clearly erroneous, because it will provide the only available review. The transferee district court can properly afford reconsideration of a ruling even when the appellate court for the transferor circuit refused extraordinary relief, because the difference in applicable legal standards makes the issue presented different from that presented to the appellate court. $^{164}$

Second, the anomaly in the district court affording "review" when its appellate court cannot do so is illusory. The statutory limits on appellate jurisdiction, ${ }^{165}$ and constructions thereof, are addressed only to appellate courts and appellate review, and not to coordinate district courts and the sort of "review" they are authorized to afford to interlocutory rulings before final judgment is entered. Moreover, once a trans-

161 See supra note 160.

162 As to the difficulty of obtaining extraordinary relief and the exceptions to the final judgment Rule, see 15 WRIGHT \& MILLER, supra note 7, § 3901; 16 WRIGHT \& MILLER, supra note 7, $\S \S 3920-3936$.

${ }^{103}$ This exception typically is phrased to allow departure from law of the case only when the existing ruling must be changed to avoid clear error and manifest injustice. See, e.g., Todd Shipyards Corp. v. Auto Transp., S.A., 763 F.2d 745 (5th Cir. 1985).

104 See supra note 36.

16528 U.S.C. \& 1294 (1982). 
feree district court has reconsidered a prior ruling, the transferee court's own action is reviewable, ${ }^{\mathbf{1 0 6}}$ opening a channel by which the transferee appellate court can reach the merits of the underlying issue. In a sense, then, it is the refusal of the transferee district court to reconsider a transferor court's ruling that stands in the way of transferee appellate court review of an issue, rather than the unavailability of such appellate review blocking the transferee district court from affording reconsideration under the "clearly erroneous" exception to law of the case doctrine.

The adoption or rejection of the "competence" principle with respect to issues of federal law will have effects under this regime as well. A transferee district court, subscribing to the competence principle and asked to reconsider a transferor court ruling that is clearly erroneous under the view of substantive federal law taken in the transferee circuit, would allow reconsideration and change the ruling. Its action would be reviewable in "its" appellate court. By comparison, if a transferee district court that follows Van Dusen even as to issues of substantive federal law is asked to reconsider a transferor court ruling, it would inquire whether that ruling was clearly erroneous under the view of substantive federal law taken in the transferor circuit. If it found the transferor court's ruling to be erroneous, the transferee court would allow reconsideration and change the ruling. Its action would be reviewable in "its" appellate court. ${ }^{167}$ As we noted, if reconsideration is not

${ }^{186}$ Cf. Nascone v. Spudnuts, Inc., 735 F.2d 763, 766 (3d Cir. 1984) (refusal of transferee court to retransfer may be reviewed by transferee appellate court on petition for mandamus or upon appeal from final judgment); Linnell v. Sloan, 636 F.2d 65, 67 (4th Gir. 1980) (transferee appellate court would gain jurisdiction if plaintiff moved for retransfer in transferee district court); Illinois Tool Works, Inc. v. Sweetheart Plastics, Inc., 436 F.2d 1180, 1188 (7th Cir.) (defendants did not sustain their burden of establishing the propriety of retransfer), cert. dismissed, 403 U.S. 942 (1971); Purex Corp. v. St. Louis Nat'l Stockyards Co., 374 F.2d 998, 1000 (7th Cir.) (absent motion to retransfer made in transferee district court, Seventh Gircuit had no power to adjudicate allegedly erroneous transfer by district court in Eighth Gircuit), cert. denied, 389 U.S. 824 (1967).

167 In some circumstances, reconsideration would be warranted when controlling law in the transferor circuit has been changed by an intervening decision. If review still would be available in the transferor circuit by way of extraordinary writs such as mandamus and prohibition, under the All Writs Act, 28 U.S.C. $§ 1651$ (1982), then it would be preferable for the parties to seek relief from that appellate court. A transferee court could, if necessary, return the files in the transferred case so that the transferor circuit court could obtain jurisdiction. See In re Nine Mile Ltd., 673 F.2d 242, 244 n.5 (8th Cir. 1982) (per curiam) (mandamus used to order transferring judge to ask transferee court to return case files). When the files in a case are physically transferred to the transferee district, the transferor court loses all jurisdiction of the case. See Starnes v. McGuire, 512 F.2d 918, 924 (D.C. Cir. 1974) (en banc); In re Southwestern Mobile Homes, Inc., 317 F.2d 65, 66 (5th Cir. 1963) (per curiam). However, if review by the appellate circuit for the transferor court is no longer possible, the transferee court 
afforded at the district court level, then transferee appellate court review of the issue will be unavailable in these circuits.

The unreviewability of the transferor court's ruling in the transferee appellate court might tempt a transferee judge to invoke law of the case when she otherwise would properly find that reasons exist to afford reconsideration. This would be undesirable and an erroneous application of law of the case principles. If, for example, relevant evidence is newly available or if the issue is subject matter jurisdiction, indispensable parties, or other immediately dispositive matters, ${ }^{168}$ reconsideration should be afforded if, but for the transfer, it would be granted.

\section{c. Forum Shopping and the Decision to Transfer}

Another complication that arises after a 1404 transfer is whether the initial judge's rulings should be given extraordinary deference simply because she sits in a different judicial district. Federal district court judges often are reluctant to reconsider rulings made by fellow jurists of equal status in other districts. ${ }^{168}$ Yet, notions of comity and concern about other judges' sensibilities should not take precedence over doing justice for litigants. After transfer, reconsideration is not available from the judge who initially ruled because the case is now out of her jurisdiction. This tends to favor reconsideration by the transferee judge.

A section 1404 transfer, however, reflects forum shopping for a more convenient forum. If there is evidence that the movant for transfer argued for a particular transferee forum because of the favorable nature of its law, the policy against forum shopping ${ }^{170}$ supports the transferee court's reluctance to disturb a prior ruling. This argument is not weakened by the fact that transfers are made to particular districts and divisions, rather than to particular judges. Although a motion to trans-

properly can decide that a change in controlling law in the transferor circuit (whose law continues to apply to the case) justifies reconsideration of a transferor court's ruling.

I68 See supra text accompanying notes 40-44.

169 See, e.g., Hayman Cash Register Co. v. Sarokin, 669 F.2d 162, 169 (3d Cir. 1982) ("Adherence to law of the case principles is even more important in this context where the transferor judge and the transferee judge are not members of the same court. Here, the principles of comity among courts of the same level of the federal system provide a further reason why the transferee court should not independently re-examine an issue already decided by a court of equal authority."); Kuenz v. Goodyear Tire \& Rubber Co., 617 F. Supp. 11, 14 (N.D. Ohio 1985) (absent "a change in the factual or legal underpinnings" upon which transferor court's decision was based, transferee court declines to review class certification, although it maintains the power to modify previous orders); $c f$. United States v. Eilberg, 553 F. Supp. 1, 3 (D.D.C. 1981) (a district judge acting in aid of a proceeding in another district court will defer to the law of the case established by that court, unless clearly compelling reasons exist for not doing so).

170 See supra notes $112-15$ and accompanying text. 
fer ordinarily is not advanced in order to judge shop, if a litigant knows that a more favorable interpretation or understanding of the law prevails in a potential transferee forum, she can urge that forum upon the initial court, and thereby shop for a more favorable forum, without having to shop for any particular judge.

It is true that the effort to forum shop can have succeeded only because the transferor court agreed that the statutory requirements for transfer were met. A transfer motion grounded upon the moving party's desire to put the issues before a court favorably disposed to her is unlikely to have satisfied the initial court that transfer was "in the interest of justice."171 Litigants who have grounds to transfer "in the interest of justice," however, may also be seeking transfer in search of favorable law.

Other things being equal, evidence that the transfer was motivated by a desire to alter the applicable law should have some impact on the decision whether to afford reconsideration of legal issues previously decided. The preceding materials have indicated, however, that a section 1404 transfer can lead to a change of applicable law only on issues of federal law or when plaintiff was the movant, and in most jurisdictions not even in those circumstances. ${ }^{172}$ Consequently, in the usual case, evidence of litigant efforts to shop for favorable law will be absent. The barriers to reconsideration should not be raised merely because the case has been transferred to a different judicial district. "Transfer should no more freeze prior rulings than it should require their reexamination."173

Courts have often ignored or failed to see the several complications that have been described here. Proceeding directly to the "merits" under their own law of the case doctrine, without attention to appellate jurisdictional considerations or the questionable effects of the "competence" principle, transferee courts typically have received the law of the case argument hospitably. ${ }^{174}$ Where an exception to the governing doctrine has been applicable, they have afforded reconsideration. ${ }^{175}$ Most

17128 U.S.G. $\S \S 1404(a), 1406(a)$ (1982).

172 See supra note 109. But see infra note 196.

175 1B MOORE's Federal Practice, supra note 7, II 0.404 [4.-2], at 128-29.

174 See, e.g., Erie Conduit Corp. v. Metropolitan Asphalt Paving Ass'n, 560 F. Supp. 305, 306-08 (E.D.N.Y. 1983) (transferor judge's rulings denying defendants' motions to dismiss complaint, for summary judgment, and for order precluding introduction of certain evidence stood as law of the case in view of absence of intervening contrary authority and of clear error or manifest injustice).

175 See, e.g., Holzsager v. Valley Hosp., 482 F. Supp. 629, 630-34 (S.D.N.Y. 1979) ( $\$ 1404$ transferee court, where case had begun and to which case had been "remanded," would reconsider transferor judge's ruling that federal courts lacked subject matter jurisdiction, in light of the centrality of the issue and new arguments 
frequently, the order challenged has been the transfer order itself. ${ }^{176}$ The courts generally have been quite adamant that the transfer order should not be reviewed by the transferee court, ${ }^{177}$ although such courts may entertain either motions to retransfer when post-transfer events have frustrated the original purpose of transfer ${ }^{178}$ or motions to dismiss for forum non conveniens. ${ }^{179}$

Insofar as a section 1404 transfer decision is discretionary, the better rule is for transferee courts to refuse reconsideration of the transfer order unless they believe that an error or a clear abuse of discretion has been committed. ${ }^{180}$ Differences remain, however, in the courts' views of when there is statutory authority to make such a transfer. ${ }^{181}$ When the

presented; suggestion that transferee court should remand to state court was too tentative to be binding).

178 This is what my research found. The proposition also is circumstantially supported by the fact that one finds the same emphasis on transfer orders in 1 MoorE's Federal Practice, supra note 7, TI 0.145 [4.-4], at 1602-05 (discussing law of the case and transfer), and 1B MOORE's Federal Practice, supra note 7, 10.404 [8], at 156-66 ("Law of the Case").

177 See, e.g., In re Cragar Indus., Inc., 706 F.2d 503, 505 (5th Cir. 1983) (such independent review would threaten repose and decisional order and create a risk of cases being tossed back and forth); Skil Corp. v. Millers Falls Co., 541 F.2d 554, 55859 (6th Cir.) (transfer order which Seventh Circuit refused to set aside by mandamus was the law of the case; the court observed, however, that it might be willing to depart from law of the case if a defendant were objecting to the transfer because there existed no proper venue as to her in the transferee district), cert. denied, 429 U.S. 1029 (1976); Starnes v. McGuire, 512 F.2d 918, 924 (D.C. Cir. 1974) (en banc) (a transferee court cannot directly review the transfer order itself); United States v. Koenig, 290 F.2d 166, 173 n.11 (5th Cir. 1961) (transferee district should not retransfer except under the most impelling and unusual circumstances or if the transfer order is manifestly erroneous); see 1 MOORE's FEDERAL PRACTICE, supra note 7, II 0.145[4.-4], at 1602-05.

${ }^{178}$ See In re Cragar Indus., Inc., 706 F.2d at 505 (declining to adopt a per se rule forbidding a return of a transferred case by the transferee court); Hite v. Norwegian Caribbean Lines, 551 F. Supp. 390 (E.D. Mich. 1982) (case transferred from Eastern District to Western District of Michigan and then back to Western District because that court failed to afford parties opportunity to be heard regarding venue and transfer).

${ }^{170}$ See Reyno v. Piper Aircraft Co., 630 F.2d 149, 156 (3d Cir. 1980) (statutory transfer on defendant's motion did not preclude defendant from seeking a forum non conveniens dismissal, although it was appropriate for the court to weigh the prior transfer as a consideration against transfer), rev'd on other grounds, 454 U.S. 235 (1981); Grodinsky v. Fairchild Indus., Inc., 507 F. Supp. 1245, 1248 (D. Md. 1981) (federal district courts have inherent power to dismiss a suit pursuant to the doctrine of forum non conveniens even though a transferee court ordinarily should not review the transfer decision).

180 See supra text accompanying notes 46-55.

181 Compare In re Fine Paper Antitrust Litig., 685 F.2d 810, 819 (3d Cir. 1982) ( $\$ 1404$ permitted transfer to a district in which venue would have been improper as to later settling defendants when the complaints were filed because, at the time of transfer, the district was one in which the action might have been brought as to all the remaining parties), cert. denied, 459 U.S. 1156 (1983) and A.J. Indus., Inc. v. United States Dist. Ct., C.D. Cal., 503 F.2d 384 (9th Cir. 1974) (on the ground that the claim made 
conflicting views of the courts involved clash as to a particular transfer, the choice of governing interpretation will determine whether the transferee court finds an error justifying reconsideration and reversal.

\section{Section 1406 Transfers}

Whether federal or state claims are at issue, the analysis changes somewhat when the focus shifts to actions transferred under section 1406. ${ }^{182}$ In these situations, the transferor court was not a proper venue. ${ }^{183}$ Consequently, the issues newly presented are decided by a transferee court by reference to the law it would have used had the case been commenced in the transferee district. ${ }^{184}$ Are rulings by the transferor court accorded respect under law of the case doctrine? The distinction again must be drawn between the choice of law question, that is, whose law of the case doctrine should apply, and the content question, or, what the applicable doctrine dictates. When there is no conflict between the law of the case doctrines of the transferor and transferee courts, no selection of one law in preference to the other need be made. For the reasons already presented, however, particularly the analogy to full faith and credit principles, ${ }^{185}$ the law of the case doctrine of the transferor court should apply in cases of conflict. This conclusion is subject to certain caveats, however, which become part of the doctrine's ideal content.

in the transferred suit could have been raised as a counterclaim in a suit filed by the defendant in the transferee district, the court upheld a transfer to a district where jurisdiction originally would not have been proper) with Ledesma-Valdes v. Sava, 604 F. Supp. 675, 679-80 n.12 (S.D.N.Y. 1985) (petition for habeas corpus could not be transferred to Western District of Texas, the place to which illegal aliens had been moved, since the action could not have been brought there; critical time in determining whether an action might have been brought in a district is the time when suit was instituted) and Allegaert v. Chemical Bank, 432 F. Supp. 685, 686 (E.D.N.Y. 1977) (party that assumed defendant's liabilities and was substituted as defendant could not transfer to district of its own residence, on the same rationale as in the above cited case).

18228 U.S.C. § 1406 (1982).

183 But see infra note 199.

18t See, e.g., Nelson v. International Paint Co., 716 F.2d 640, 643-44 (9th Gir. 1983) (use of $\S 1406$ transferee court's law prevents forum shopping at commencement of the suit and denies plaintiffs choice of law advantages to which they would not have been entitled in a proper forum); Ellis v. Great Southwestern Corp., 646 F.2d 1099, 1109-11 (5th Cir. 1981) ( $\$ 1406$ transferee court must apply the choice of law rules of the state in which it sits); Davis v. Costa-Gavras, 580 F. Supp 1082, 1086-87 (S.D.N.Y. 1984) (when transferor court has not ruled, transferee court must determine whether jurisdiction and venue were proper in the transferor court to decide which forum state's law will apply); Haire v. Miller, 447 F. Supp. 57, 63-64 (N.D. Miss. 1977) (limitations period to be applied is that of the $\S 1406$ transferee forum).

18s See supra notes $132-38$ and accompanying text. 


\section{a. The Nature of the Transferor Court's Rulings}

In considering what should occur, it is useful to consider the nature of a section 1406 transfer court's rulings. Section 1406 properly can be invoked only when a party has interposed a timely and sufficient objection to the venue. ${ }^{188}$ Under Rule 12 of the Federal Rules of Civil Procedure, the defense of improper venue can be raised only in a preanswer motion or, if no Rule 12 motion was made, in the answer to the complaint, or in an amended answer permitted as a matter of course. ${ }^{187}$ Consequently, virtually the only matters that a transferor court might have ruled upon before entering its transfer order under section 1406 are the defenses listed in Rule $12 . .^{188}$

In general, a transferee court should honor the transferor court's decisions on Rule 12 defenses and should follow that court's law of the case doctrine. Because of the dispositive nature of the issues involved in Rule 12 motions, however, a transferee court often will reconsider to reconsider the transferor court's decisions on these matters. If the transferee court reverses the previous court's rulings on whether it had proper jurisdiction over the case or parties, that decision will have consequences for the transferee court's application of law of the case principles in other areas.

Any court has jurisdiction to determine whether it has subject matter jurisdiction. ${ }^{189} \mathrm{~A}$ court that had concluded it lacked subject matter jurisdiction would dismiss, not transfer. ${ }^{100}$ The section 1406 transferor court's ruling that it had subject matter jurisdiction would be entitled to whatever deference law of the case principles mandate. The issue of subject matter jurisdiction, however, is typically afforded reconsideration. When the transferor court had subject matter jurisdiction over the case and personal jurisdiction over the parties, and was merely an im-

188 See 15 Wright \& Miller, supra note 7, § 3827, at 268.

187 See FED. R. CIv. P. 12(g), (h)(1).

188 These include the defense of "(1) lack of jurisdiction over the subject matter, (2) lack of jurisdiction over the person, (3) improper venue, (4) insufficiency of process, (5) insufficiency of service of process, (6) failure to state a claim upon which relief can be granted, (7) failure to join a party under Rule 19." FED. R. Grv. P. 12(b). A court might also have ruled upon motions for extension of time to answer or otherwise plead. The same time and "substance" constraints do not operate when a motion for transfer is made in a district court under 28 U.S.C. $\S 1404$.

189 See Land v. Dollar, 330 U.S. 731, 739 (1947) (district court has jurisdiction to determine its jurisdiction); United States v. United Mine Workers, 330 U.S. 258, 292 n.57 (1947) (a court has jurisdiction to determine its own jurisdiction); Lambert v. Conrad, 536 F.2d 1183, 1185 (7th Cir. 1976) (court's jurisdiction determination is binding unless reversed on appeal).

100 But see American Fidelity Fire Ins. Co. v. U.S. Dist. Ct., N.D. Cal., 538 F.2d 1371, 1373 (9th Cir. 1976) (district court that concluded it lacked subject matter jurisdiction transferred claim to the Court of Claims under 28 U.S.C. § 1406(c) (1982)). 
proper venue, law of the case principles also should apply to its other rulings, as the defects in the original court were not jurisdictional. Thus, for example, when such a court also has denied a motion to dismiss for failure to state a claim on which relief can be granted or a motion to dismiss for lack of indispensable parties, its decisions are entitled to the same respect under law of the case doctrine that those rulings would command if the transferor court were a proper venue. As it happens, most courts freely afford reconsideration of such rulings. ${ }^{191}$

But what if the transferee court decides, on reconsideration, that the transferor court lacked subject matter jurisdiction over the case? In that circumstance, the same factors that determine whether a judgment by the transferor court would have been subject to collateral attack should determine whether law of the case principles should apply to any other rulings of the transferor court. ${ }^{192}$ In both instances, one must balance the policies underlying finality against the policy of prohibiting a court from exceeding its powers. ${ }^{193}$ Of course, if, as is likely, the transferee court also lacks subject matter jurisdiction it should simply dismiss.

Any court also has jurisdiction to determine whether it has personal jurisdiction, and to examine the related questions of sufficiency of process and of service. ${ }^{194}$ A section 1406 transferor court's rulings that

191 See Thomas v. James, 661 F.2d 67, 68 n.3 (5th Cir. 1981) ("II]t is incumbent on a federal court to dismiss whenever it appears that jurisdiction is lacking.").

${ }^{192}$ See Restatement (Second) of Judgments $\$ \S 65,69$ (1982); RestateMENT OF JUDGMENTS § 10 comment b (1942); see also UAW v. Donovan, 756 F.2d 162, 163-65 (D.C. Cir. 1985) (where district court had lacked jurisdiction over suit seeking a mandatory injunction against a federal agency, as determined by a District of Columbia Circuit decision rendered after the district court had acted, appellate court would treat district court's orders as law of the case and reexamine them only for compelling reasons upon transfer of the case to the appellate court); Wilson v. Turnage, 755 F.2d 967, 967-68 (D.C. Cir. 1985) (when District of Columbia Circuit had decided, on the merits, issues raised in a case over which the Federal Circuit had exclusive appellate jurisdiction, the District of Columbia Circuit vacated its opinion and judgment and transferred the case to the Federal Circuit, but recommended that the Federal Circuit adopt its opinion to conserve judicial resources and avoid inequitable treatment of the litigants); Dynalectron Corp. v. United States, 4 Cl. Cit. 424, 431 (1984) (upon transfer pursuant to 28 U.S.C. $\S 1631$, transferor court rulings were respected as law of the case), affd mem., 758 F.2d 665 (Fed. Cir. 1984).

193 Of course, interlocutory rulings are not supported by the policies favoring finality to the same extent that final judgments are. See F. JAMEs, JR. \& G. HAZARD, JR., Crvil Procedure, § 11.2, at 588 (3d ed. 1985) (stating that until final judgment, modern procedure gives greater weight to the goal of full development of the issues in a case than to the goal of prompt and economical termination of the matter).

194 See Baldwin v. Iowa State Traveling Men's Ass'n, 283 U.S. 522 (1931) (trial court's unappealed denial of defendant's motions to set aside service and dismiss for lack of personal jurisdiction was conclusive; having contested those issues, defendant was precluded from collaterally attacking the judgment rendered against it); Familia de Boom v. Arosa Mercantil, S.A., 629 F.2d 1134, 1137 (5th Cir. 1980) (principle is well- 
it had personal jurisdiction, and that process and service were sufficient, similarly would be entitled to whatever deference law of the case principles would mandate. Because of their potentially dispositive nature, however, they typically also are afforded reconsideration. Unlike the lack of subject matter jurisdiction, however, a transferor court's conclusion that it lacked personal jurisdiction, or that service or process was bad, would not necessarily lead to dismissal. The Supreme Court decided in Goldlawr v. Heiman ${ }^{195}$ that section 1406 permits transfers when the transferor court lacked personal jurisdiction over defendants. ${ }^{196}$ Because a court has jurisdiction to determine its own jurisdiction, ${ }^{197}$ the defendant having submitted herself to the court for that specific purpose, the transferor court's decision that it lacked personal

settled that a court has jurisdiction to determine its own jurisdiction, subject to appellate review), cert. denied, 451 U.S. 1008 (1981).

198369 U.S. 463 (1962).

198 Cases following and expanding upon Goldlawr include: Martin v. Stokes, 623 F.2d 469, 474 (6th Cir. 1980) (arguing that $\S 1406$ is the appropriate basis for transferring where personal jurisdiction is lacking, but venue is proper); Corke v. Sameiet M.S. Song of Norway, 572 F.2d 77, 79 n.7 (2d Cir. 1978) (same); Aguacate Consol. Mines, Inc. v. Deeprock, Inc., 566 F.2d 523, 524-25 (5th Cir. 1978) (in case of improper venue, removed cases meeting federal standards of a $\$ 1406$ transfer of venue may, in the interest of justice, also be transferred); O'Neal v. Hicks Brokerage Co., 537 F.2d 1266, 1268-69 (4th Cir. 1976) (rather than dismissing suit, the district court should have allowed the transfer of the case to a district where it could have been brought); Mayo Clinic v. Kaiser, 383 F.2d 653, 655-56 (8th Cir. 1967). Subject matter jurisidiction in a $\S 1406$ transferor court is essential, however. See First Nat'l Bank v. United Air Lines, Inc., 190 F.2d 493, 496 (7th Cir. 1951) (federal district court in Illinois having no subject matter jurisdiction had no power to transfer the case to federal district court in another state under § 1406(a)), rev'd on other grounds, 342 U.S. 396 (1952); Raese v. Kelly, 59 F.R.D. 612, 615 (N.D. W. Va.) (1973) (where there was no subject matter jurisdiction because diversity was lacking, court had no alternative but to dismiss and could not transfer); Corke v. Sameiet M.S. Song of Norway, 572 F.2d at 79 n.6. A different statute, 28 U.S.G. § 1631 (1982), allows transfer if the federal court in which suit was brought lacks subject matter jurisdiction of the case but a different federal court would have such jurisdiction over it.

In order to avoid an anomaly, several courts have made or upheld transfers under 28 U.S.C. $§ 1404$ where personal jurisdiction was absent but venue was proper. At least one treatise approves this tack, taking the position that, in the described circumstances, the Goldlawr principle should be applied by analogy to transfers under $\S 1404(\mathrm{a})$, rather than extending § 1406(a). See 15 WRIGHT \& Miller, supra note 7, $\S 3827$, at 264-65. In those cases, too, law of the case doctrine should operate, or not, as described supra in text accompanying notes 191-95. When a transfer is made by a court lacking personal jurisdiction over the defendant, the transferee court's law is held to apply to newly presented issues whether or not venue was proper in the original forum and whichever transfer statute is invoked. See, e.g., Ellis v. Great Southwestern Corp., 646 F.2d 1099, 1110 (5th Cir. 1981) (transferee court should apply the choice of law rules of the state where it sits following a \$ 1404(a) transfer from a district in which personal jurisdiction over the defendant was unobtainable); Wooldridge v. Beech Aircraft Corp., 479 F. Supp. 1041, 1059 (W.D. Mo. 1979); Brown v. Merrow Mach. Co., 411 F. Supp. 1162, 1163-64 (D. Conn. 1976).

197 See supra note 194. 
jurisdiction would be entitled to respect under law of the case doctrine.

As to its other rulings, however, different reasoning applies. If a court lacking personal jurisdiction takes a case to judgment, its judgment is subject to reversal, and its default judgment is subject to collateral attack under the fifth or fourteenth amendments to the Constitution as a due process violation. ${ }^{198}$ Therefore, as a corollary, if it is established in either the transferor or transferee court that the transferor court lacked personal jurisdiction over the defendants, no weight should be given to any other rulings by the transferor court. Its interlocutory rulings, like any ultimate judgment it might have rendered, are in violation of defendant's due process rights.

Finally, a section 1406 transferor court's ruling that it is not a proper venue should not have the same effect as a finding of lack of jurisdiction on the transferee court's application of law of the case principles to other matters. Every court has authority to determine whether it is a proper venue. ${ }^{189}$ Thus, the transferor court's conclusion that it is not a proper venue is entitled to respect under law of the case doctrine. ${ }^{200}$ In other words, the fact that the ruling court was an improper venue is not itself a ground to deny deference under law of the case doctrine. ${ }^{201}$ By the same token, a party who has sought transfer thereby submits to the court of improper venue the question whether particular other fora are sites where the action could have been brought. Absent defects in the transferor court's jurisdiction, its conclusions as to the propriety of other venues are entitled to some weight.

198 Pennoyer v. Neff, 95 U.S. 714, 728-30 (1877).

199 See 15 WRIGHT \& MilleR, supra note 7, § 3826, at 259 ("If a proper objection is made to venue, it is for the court to determine whether the objection is well taken.").

${ }^{200}$ See Gulf Research \& Dev. Co. v. Schlumberger Well Surveying Corp., 98 F. Supp. 198, 199-201 (D. Del. 1951) (where a patent infringement suit was transferred by one district court to another on the ground that venue was improper because the defendant had committed no act of infringement in the first district, the second court would not reexamine the question of venue already decided since to do so would usurp an appellate function), mandamus denied, 193 F.2d 302 (3d Cir. 1951), affd by an equally divided court per curiam, 344 U.S. 861 (1952).

${ }^{201}$ It has been said, "There should never be any reason for the transferee court to reexamine the decision of the transferor court that venue was improper in that district, since even if that decision were incorrect the transfer could have been ordered under $\S$ 1404(a)." 15 WRIGHT \& MilleR, supra note 7, § 3827, at 276. However, since the propriety of the original venue often determines whether the transferee or the transferor court's law will govern a case, it has significance which may warrant reexamination of the transferor court's conclusion. See, e.g., Translinear Inc. v. Republic of Haiti, 538 F. Supp. 141, 143 (D.D.C. 1982) (the "determining factor" for deciding whether to apply the statute of limitations of the transferor or transferee court is whether the transferor court correctly determined that it had improper venue under $\S 1406$ (a) or whether the case was transferred in the "interest of justice" pursuant to $\S 1404(a)$ ). 
b. The Effects of Appellate Jurisdictional Limits and Choice of Law in Section 1406 Transfers

Because a section 1406 transferee court will decide the merits of issues under the law that it would have applied had the action been commenced there, a section 1406 transferee judge who is asked to reconsider a prior ruling under a clearly erroneous exception to law of the case doctrine will test for error against the law that governs in the transferee district. If the transferee district court sits in a circuit that will assert appellate jurisdiction to review decisions rendered by transferor courts in other circuits, ${ }^{202}$ this tack will be essential to avoid reversal.

Even if the transferee district court sits in a circuit that holds itself to lack jurisdiction to review such out-of-circuit decisions, the transferee court still should reconsider the transferor court's rulings in light of the law prevailing in the transferee district. The litigation then will be governed by properly applicable law and not by law that was applied solely by dint of the commencement of the action in an inappropriate forum. ${ }^{203}$ In addition, the unreviewability of the transferor court's rulings in the transferee appellate court should not cause a transferee judge to invoke law of the case when she otherwise would find that reasons exist to afford reconsideration. ${ }^{204}$

\section{c. Forum Shopping and the Decision to Transfer}

The decision to transfer under section 1406 raises two additional law of the case concerns. First, should a determination that transfer was motivated by forum shopping affect a transferee court's application of the doctrine? Second, under what circumstances should a transferee court be willing to reconsider and even to reverse the transferor court's decision to grant a section 1406 transfer?

The main argument against application of the doctrine in section 1406 transfer cases seems to be that because the initial court was an improper venue, or lacked personal jurisdiction over the defendant, it had no right to apply its law. Thus, reconsideration of its rulings would appear to be particularly appropriate. We have seen, however, that subject to specific limitations deriving from the absence of subject matter or personal jurisdiction, the decisions of the original court are due

${ }^{202}$ See supra text accompanying note 152.

${ }^{203}$ Cf. Manley v. Engram, 755 F.2d 1463, 1470 (11th Cir. 1985) ("Since the original forum was not a proper one . . ., no sound reason exists to apply that forum's choice of law rules.").

${ }^{204}$ See supra text accompanying notes 161-68. 
deference. ${ }^{205}$ Moreover, where more than one venue was proper, the defendant may have advocated selection of the transferee forum because its law favored her. In such a circumstance, the policy against forum shopping arguably supports reluctance to disturb a prior ruling. Thus, other things being equal, evidence that the transferee forum was sought for its law should have some impact on the decision whether to afford reconsideration of legal issues previously decided. Where evidence of such forum shopping is absent, however, barriers to reconsideration should not be raised merely because the case was transferred to a different judicial district.

As was true under section 1404, the order of a section 1406 transferor court most frequently triggering a request for reconsideration is the transfer order itself. ${ }^{206}$ Typically, courts have invoked law of the case to avoid reconsideration of the transfer order and of the underlying findings that supported the order. A noteworthy example is Hayman Cash Register Co. v. Sarokin. ${ }^{207}$ In Hayman, because of inadequate consideration to the law of the case, the Court of Appeals for the Third Circuit granted a petition for writ of mandamus requiring a New Jersey district judge to vacate his order retransferring a case to the District of Columbia. The District of Columbia trial court had transferred under 28 U.S.G. $\S 1406($ a), in an order explicitly stating the findings that personal jurisdiction and proper venue existed in New Jersey at the commencement of the suit. ${ }^{208}$ After transfer, the plaintiff moved to retransfer back to the District of Columbia on the grounds that the transfer was not permissible under the statute because New Jersey lacked personal jurisdiction over the defendants at commencement of the suit and hence was not a district in which the action could have been brought. ${ }^{209}$ Believing that he was free independently to examine whether the statutory requirement was met, and agreeing with this contention, the New Jersey district judge granted the motion.

The Third Circuit rejected the suggestion that the Supreme Court's decision in Hoffman v. Blaski ${ }^{210}$ created an exception to the law of the case doctrine for transfer orders. The court instead read Hoffman to allow a transferee court independently to determine its venue and jurisdiction "only when this determination has not previously been made by the transferor court."211 The court then elaborated

${ }^{205}$ See supra notes 187-201 and accompanying text.

200 This is what my research found. See supra note 176.

207669 F.2d 162 (3d Cir. 1982).

${ }^{208}$ Id. at 164.

209 Id.

210363 U.S. 335 (1960); the case is discussed supra at note 154.

${ }^{211}$ Hayman, 669 F.2d at 165-67 \& n.4; accord, supra note 154. 
upon the reasons traditional law of the case principles should govern the propriety of a transfer order. It found persuasive the arguments of Justice Frankfurter, dissenting in Hoffman, that as a matter of public policy and good administration of justice, those who have contested an issue should be bound by the result, and that the repeated consideration of the propriety of transfer unduly delays attention to the merits of the controversy. ${ }^{212}$ It also agreed that the principle of comity among courts and among judges of different courts of equal authority made adherence to law of the case principles particularly important in a transfer situation. ${ }^{213}$ The court indicated that a transferee court properly could consider the propriety of a transfer if any of the recognized exceptions to law of the case doctrine were applicable. ${ }^{214}$ It then remanded for the district court to consider whether any of the exceptions applied and, if not, to deny the motion to retransfer. ${ }^{215}$

Although the Hayman opinion is generally well reasoned, it is open to question with respect to its choice of law and one facet of its content. Like most courts, the Third Circuit applied its own law of the case doctrine to a ruling by an outside district court, without explicit consideration of the propriety of that choice of law, and despite its recognition that its law of the case doctrine differed from that of several other circuits. ${ }^{218}$ The better approach would have been for the Third Circuit to apply, and to direct its district court in New Jersey to apply, the law of the case doctrine of the District of Columbia transferor court. $^{212}$

The content of the law of the case doctrine applied by the Third Circuit is also subject to criticism in one respect: the Third Circuit had

212 Hayman, 669 F.2d at 167, citing Hoffman, 363 U.S. at 348-49 (Frankfurter, J. dissenting). See also Gulf Research \& Dev. Co. v. Schlumberger Well Surveying Corp., 98 F. Supp. 198, 201 (D. Del. 1951) (observing, "[I]f both Judge Harrison and I were obdurate in our positions, this case could conceivably shuttle back and forth interminably"), mandamus denied, 193 F.2d 302 (3d Cir. 1951), aff'd by an equally divided court per curiam, 344 U.S. 861 (1952). The Third Gircuit reminded litigants who believe that the transfer decision is erroneous that they can seek reconsideration in the transferor court or seek mandamus from the circuit for the transferor court. Hayman, 669 F.2d at 168-69. Although such initiatives would cause delay, they cause less delay than reconsideration and appellate review in two circuits and avoid the other problems entailed by the course followed by plaintiffs here.

218 See Hayman, '669 F.2d at 167, 169; accord Hoffman, 363 U.S. at 349 (Frankfurter, J., dissenting); Gulf Research \& Dev. Co., 98 F. Supp. at 201.

214 Hayman, 669 F.2d at 169-70.

$218 I d$. at 170.

218 The Third Circuit had not yet recognized as an exception to the doctrine that the prior decision was clearly erroneous and would work a manifest injustice. See id. at 170 n.10. But see supra text accompanying notes 64-66. No one had contended that the exception applied in this case.

${ }^{217}$ See supra notes $132-38$ \& 185 and accompanying text. 
not indicated that the determinations supporting the District of Columbia court's transfer order should be denied law of the case effect if that court had lacked personal jurisdiction. The District of Columbia district court had had before it a motion to dismiss for lack of personal jurisdiction but had not reached that issue. ${ }^{218}$ As a result, the New Jersey court would have been free to consider that issue without any predisposition flowing from law of the case doctrine.

The error of the Third Circuit becomes evident if one assumes that on remand the New Jersey district judge would have found no exceptions to law of the case to be applicable. It then would have had to vacate its order of retransfer. If the New Jersey court then proceeded to judgment, its judgment would not have been subject to collateral attack, for the defendants already had been heard in the District of Columbia on the question of the New Jersey court's ability to assert personal jurisdiction over them. ${ }^{\mathbf{2 1 9}}$ The Third Circuit would have had jurisdiction to review the New Jersey district court's judgment and such interlocutory orders as the denial of retransfer, but its focus as to the latter would have been whether the lower court had properly applied law of the case doctrine. It seems unlikely that, after trial and in light of its own prior opinion, the Third Circuit would have reversed the New Jersey district court for giving deference to the District of Columbia court's transfer order. But if the District of Columbia court lacked personal jurisdiction, its determination that the New Jersey court had such jurisdiction was not due any deference. The district court of New Jersey's original decision that New Jersey was not a district in which the action could have been brought should have stood, unless reversed on appeal as erroneous. Yet, as the case actually presented itself, that determination would not receive meaningful review on appeal to the Third Circuit. Furthermore, it is not clear whether the Third Circuit would hold itself to have jurisdiction to review the District of Columbia court's transfer order and the findings supporting it, including the finding that the New Jersey district court had jurisdiction, since the court has thus far avoided addressing the question of such "extraterritoriality."220 After the transfer, the transfer order and underlying findings would not be reviewable in the District of Columbia Gircuit either. ${ }^{221}$

218 Hayman, 669 F.2d at 163.

218 A defendant may collaterally attack a judgment for lack of personal jurisdiction only if he defaulted in the underlying action. Baldwin v. Iowa State Traveling Men's Ass'n, 283 U.S. 522, 524-27 (1931).

220 See supra note 160.

221 See, e.g., In re Sosa, 712 F.2d 1479, 1480 (D.C. Cir. 1983) (physical transfer of papers to permissible transferee forum deprives the court of appeals for the transferor court of jurisdiction to review the transfer). 
Plaintiff's only recourse may have been an unpromising petition for writ of mandamus to the D.C. Circuit, filed before the District of Columbia lost jurisdiction.

It is preferable for the courts to recognize that law of the case consequences should not attach to most determinations by courts lacking personal jurisdiction. Then, in a case like Hayman, the transferee court's determinations concerning both the transferor court's and its own personal jurisdiction could receive early appellate attention. Progress to judgment in courts lacking personal jurisdiction could better be avoided.

\section{Transfer Together with Consolidation}

Under Rule 42 of the Federal Rules of Civil Procedure, cases can be consolidated after some or all of them have been transferred so that all the cases in question have come to be pending in a single judicial district and division. ${ }^{222}$ After such consolidation, a litigant may seek reconsideration of a ruling made in one of the consolidated cases by a transferor judge. In these circumstances, the judge hearing the consolidated cases and facing a law of the case problem must consider all of the factors discussed earlier in this exposition as to both consolidated and transferred actions. ${ }^{23}$ She also must consider any novel problems created by the combination of transfer and consolidation.

If the question is whether to reconsider a ruling that affects only the "case of origin," the civil action in which the ruling was made, the transferee judge must decide first whose law of the case doctrine to apply. As argued earlier, when a single case is transferred under section 1404 or section 1406 and the case is in federal court under diversity or federal question jurisdiction, the law of the case doctrine of the transferor court should be used when reconsideration of one of its rulings is urged upon the transferee court and the doctrines of the two courts would lead to different results. ${ }^{224}$ This position may create problems, however, in transferred and consolidated cases when challenges are made to rulings from a number of district courts in a number of states and federal appellate circuits, differing in their law of the case doctrines. One difficulty lies in the burden of ascertaining and applying the various transferor courts' law of the case doctrines. A second

222 See 9 WRIGHT \& MILLER, supra note 7, § 2382, at 257-58 ("Actions pending in different districts may not be consolidated, but the possibility of consolidation may be a factor in persuading a court to transfer one of the actions to the district where the other is pending.") (footnotes omitted).

228 See supra notes 83-221 and accompanying text.

224 See supra text accompanying notes 132-38, 182-85. 
problem is raised by the inconsistent results that differing law of the case doctrines may produce. Except in situations where Erie would require use of the doctrines employed in the states of the transferor courts, the transferee court handling consolidated cases should have the discretion to determine whether the burden of ascertaining and applying several transferor courts' law of the case doctrines and of contending with conflicting results presents so great a threat to the economical handling of the cases that the usual choice of doctrine should be abandoned. In such a case the transferee court might use its own the law of the case doctrine or that of a single transferor court instead.

Having selected the law of the case doctrine that is to govern, the court then should proceed to consider whether, under the applicable doctrine, the prior ruling ought to be adhered to without consideration of its merits. In this context, it was argued earlier that the law ideally should take into account whether the transferor court had subject matter jurisdiction over the case and personal jurisdiction over the parties. $^{228}$ If the transferor court lacked either, its rulings on any questions other than subject matter jurisdiction and personal jurisdiction may not be entitled to credence as law of the case. ${ }^{226}$ In addition, in most courts' view, whether the transferor court was a proper venue will determine whether the transferee court will use its own "substantive" law or that of the transferor court in determining questions newly presented. This factor similarly should establish the legal reference point for determining whether the transferor court's ruling was clearly erroneous, except perhaps as to federal issues in cases transferred under section $1404 .^{227}$ The question whether the challenged ruling is subject to appellate review in the transferee circuit also is relevant. If such review is not available, reconsideration by the transferee district court may provide the only means of obtaining review.

Aside from these considerations generated by the transfer, the court should also consider the several factors pertinent in any law of the

223 See supra text accompanying notes 189-97.

228 See supra text accompanying notes 192, 198.

227 See supra text accompanying notes 109-11, 136, 184. In cases adjudicable in federal court under diversity jurisdiction, 28 U.S.C. $\S 1332$, the propriety of venue in the transferor court determines whether the transferee court will use the "substantive" law of the state where it sits or that of the state where the transferor court sat. See supra text accompanying notes 109-11, 184. As to federal question cases, Professor Marcus's view is that the law of the transferee court always should be applied. Most courts apply the law of the transferor court upon $\S 1404$ transfers. See supra note 136.

When the question is whether law of the case deference is to be afforded the transfer order itself, any transferor court must be regarded as having been a proper venue for purposes of deciding the question whether it was a proper venue and other questions of law or fact raised by the motion to transfer. See supra text accompanying notes 198-200. 
case inquiry and those that properly have a bearing because of the change of judge. ${ }^{228}$ Finally, the court must determine whether it is sensible to adhere to the challenged ruling, given the consolidation with other cases. As observed earlier, the efficiencies to be gained from consolidation depend in substantial part upon uniform handling of the consolidated cases. The usual law of the case principles must be modified to reflect the need for horizontal consistency among consolidated cases and to provide the best solution to the problems of the consolidated cases as a whole.

The question whether a ruling should be extended from the case of origin to other consolidated actions is really not a law of the case problem. $^{228}$ The litigants who would be bound for the first time are entitled to be heard on the underlying issue. ${ }^{230}$ In determining the question presented by applying whatever body or bodies of law govern the various transferred and consolidated cases, ${ }^{231}$ the court again must assess what is right or best in the consolidated actions considered in the aggregate, as well as what is right or best for any of the consolidated actions considered alone.

\section{Section 1407 Litigation}

Federal law provides for multidistrict litigation. ${ }^{282}$ Law of the case

228 See supra text accompanying notes 7-81.

229 See supra note 84 and accompanying text.

230 See supra text accompanying notes 85-87.

281 Professor Marcus argues that, when federal question cases have been transferred under 28 U.S.C. $\$ 1404$ and then consolidated, it is particularly important that the transferee court apply its own law to all the cases because the alternative of applying divergent legal standards might well undermine the gain in efficiencies and reduction in burden that consolidation is intended to provide. See Marcus, supra note 107, at 716-19.

282 The statute providing for multidistrict litigation provides in part:

(a) When civil actions involving one or more common questions of fact are pending in different districts, such actions may be transferred to any district for coordinated or consolidated pretrial proceedings. Such transfers shall be made by the judicial panel on multidistrict litigation [JPMDL] ... upon its determination that transfers for such proceedings will be for the convenience of parties and witnesses and will promote the just and efficient conduct of such actions. Each action so transferred shall be remanded by the panel at or before the conclusion of such pretrial proceedings to the district from which it was transferred unless it shall have been previously terminated: Provided, however, That the panel may separate any claim, cross-claim, counter-claim, or third-party claim and remand any of such claims before the remainder of the action is remanded.

(b) Such coordinated or consolidated pretrial proceedings shall be conducted by a judge or judges to whom such actions are assigned by the judicial panel on multidistrict litigation. For this purpose, upon request of the panel, a circuit judge or a district judge may be designated and as- 
doctrine and the additional factors that bear upon its application in transferred and in consolidated cases all are pertinent when multiple actions are transferred by the Panel to a single district for coordinated or consolidated pretrial. This part of the Article examines whether section 1407 litigation presents unique law of the case problems and will recommend how such problems should be handled.

One characteristic of section 1407 litigation is the number of judges and courts before whom the cases, or parts of them, may be pending either simultaneously or consecutively. Some portions of a civil action may be left in the court where it was commenced while other portions move through the hands of the Panel to a section 1407 transferee court. ${ }^{233}$ While in the jurisdiction of a section 1407 court, issues may be brought for resolution to courts of other districts in which discovery is proceeding. ${ }^{234}$ Much litigation ends in the section 1407 court acting as such, but those cases not terminated during pretrial may be remanded to the transferor district or may be transferred by the section 1407 court, under sections 1404 or 1406, to itself or to still other district courts. ${ }^{238}$ Thus, transferor courts, the Panel, a section 1407 court,

signed temporarily for service in the transferee district by the Chief Justice of the United States or the chief judge of the circuit, as may be required, in accordance with the provision of chapter 13 of this title. [ 28 U.S.C. ch. 13 relates generally to the assignment of judges to other courts.] With the consent of the transferee district court, such actions may be assigned by the panel to a judge or judges of such district . . . .

(c) Proceedings for the transfer of an action under this section may be initiated by -

(i) the judicial panel on multidistrict litigation upon its own initiative, or

(ii) motion filed with the panel by a party in any action in which transfer for coordinated or consolidated pretrial proceedings under this section may be appropriate.

28 U.S.C. § 1407(a), (b), (c) (1982).

283 See 28 U.S.C. $\S 1407$ (a) (1982). The terms "§ 1407 transferee court" or "§ 1407 court" are used herein to denote courts to which cases are transferred by the JPMDL for coordinated or consolidated pretrial and are to be distinguished from courts to which transfer is made, for all purposes, under 28 U.S.C. $\S 1404$ or $\S 1406$. The term " $\$ 1407$ judge" is used to denote the judge presiding in a $\S 1407$ court.

2st See FED. R. GIV. P. 30(d), quoted supra note 4. The courts to which discovery issues are brought are sometimes referred to herein as "discovery courts." Discovery issues may be put to otherwise uninvolved district courts in all federal litigation. However, as elaborated below, particularly "sticky" questions are created by this mechanism in § 1407 litigation. See infra text at notes 334-86.

23s See e.g., In re Fine Paper Antitrust Litig., 685 F.2d 810, 819-20 (3d Cir. 1982) ( $\$ 1407$ transferee court did not abuse its discretion in transferring actions to itself for trial), cert. denied, 459 U.S. 1156 (1983); Pfizer, Inc. v. Lord, 447 F.2d 122 (2d Cir. 1971) (per curiam) (same re $\S 1407$ transferee judge sitting by designation who transferred actions to his own district for trial); In re Multidistrict Civil Actions Involving the Air Crash Disaster Near Hanover, N.H. on October 25, 1968, 314 F. Supp. 62, 63 n.1 (J.P.M.D.L. 1970). 
discovery courts, remand courts, and section 1404 or 1406 transferee courts are all potentially involved in handling the litigation. Law of the case issues can arise between any two of these tribunals.

\section{A. Section 1407 Purposes}

In exploring the proper workings of and the appropriate limitations on law of the case doctrine in litigation coordinated or consolidated for pretrial under section 1407, an understanding of the purposes of the statute is essential. The overriding objective is to ensure just and efficient conduct of multidistrict litigation. To this end, a primary objective of section 1407 is to avoid or minimize conflict and duplication in discovery and other pretrial procedures in related cases by providing centralized management under court supervision. ${ }^{236}$ In the words of the Panel, the remedial purpose of section 1407 is "to eliminate the potential for conflicting contemporaneous pretrial rulings by coordinate district and appellate courts in multidistrict related civil actions." 237 "The transfer to a single jurisdiction, for pretrial proceedings, of numerous cases pending in various district courts, affords the opportunity for centralized, coordinated and consolidated management thereby avoiding the chaos of conflicting decisions and fostering economy and efficiency in judicial administration."2s8

A corollary purpose is to avoid a multiplicity of review proceedings and thus to minimize the possibilities of conflicting rulings at the appellate level. ${ }^{288}$ This goal is implemented in part by the provision in

286 H.R. REP. No. 1130, 90th Cong., 2d Sess. 2 (1968), reprinted in 1968 U.S. Code Cong. \& ADMIN. News 1898. The backdrop against which $\S 1407$ was enacted is described in 15 WRIGHT \& MrLLER, supra note 7, § 3861, at 495-501 and articles cited therein; see In re New York City Mun. Sec. Litig., 572 F.2d 49, 51 (2d Cir. 1978).

${ }^{237}$ In re Plumbing Fixture Cases, 298 F. Supp. 484, 491-92 (J.P.M.D.L. 1968).

${ }^{238}$ In re Exterior Siding \& Aluminum Coil Antitrust Litig., 538 F. Supp. 45, 47 (D. Minn. 1982), petition for writ of mandamus denied by an equally divided court en banc, 705 F.2d 980 (8th Cir.), cert. denied, 464 U.S. 866 (1983). See generally R. Marcus \& E. Sherman, Teachers Manual for Complex litigation, Cases and Materials on Advanced Crvil Procedure 73 (1985) (distinguishing the "minimalist" objective of avoiding the overburdening of parties who otherwise would be subjected to duplicative discovery from "maximalist" objectives of agglomerating related claims from around the country for adjudication in a single forum).

${ }^{280}$ S. REP. No. 454, 90th Cong., 1st Sess. 5-6 (1967); see In re Plumbing Fixture Cases, 298 F. Supp. at 492, 495 (if all pretrial proceedings after transfer and before remand are conducted in the transferee court, appellate proceedings for early review of pretrial rulings ordinarily will lie in the court of appeals for the transferee district until remand. Coordination at the appellate level will be achieved in one court of appeals, in the absence of an exceptional appeal before transfer); id. at 501 (quoting from the Report of the Co-ordinating Committee on Multiple Litigation Recommending New Section 1407, Title 28) (by providing for entry of the Panel's transfer orders in the 
section 1407(e) that no review of a pre-transfer Panel order shall be available in any forum other than the court of appeals for the district in which the Panel is holding hearings, and that no review of a Panel transfer order or subsequent Panel order shall be in any forum other than the court of appeals for the transferee circuit. ${ }^{240}$

\section{B. Law of the Case in Section 1407 Litigation}

Before looking at the several contexts in which law of the case problems can arise in multidistrict litigation, some overarching questions should be addressed. Logically, the first is: whose law of the case doctrine should apply?

This Article takes the position that ordinarily the doctrine of the court whose ruling is challenged should govern, with the proviso that in consolidated cases a transferee court should have discretion to use its own or another single law of the case doctrine when necessary in service of efficient and uniform handling of the cases. The question arises whether anything in section 1407 or characteristic of multidistrict litigation indicates a different conclusion. Nothing on the face of the statute addresses the question of whose law the transferee judge, or any other judge involved in the multidistrict litigation, should apply. It certainly does not speak to whose law of the case doctrine should govern. The legislative history of the statute does contain traces of pertinent discussion, but it is far from determinative. In hearings before the Senate subcommittee studying the bill that became section 1407, Dean Phil Neal and Judge William Becker, two witnesses who had been involved in the administration of the massive electrical equipment price fixing cases, ${ }^{241}$ testified that they saw no reason to doubt that the Van Dusen rule-that the applicable law would be that which would have been applied absent transfer-would apply under section $1407 .{ }^{242}$ This testi-

transferee district it is intended to assure that appellate review, when available, will take place in one court of appeals). See Utah v. American Pipe \& Constr. Co., 316 F. Supp. 837, 839 (C.D. Cal. 1970).

24028 U.S.C. § 1407(e) (1982). The same section provides:

No proceedings for review of any order of the panel may be permitted except by extraordinary writ pursuant to the provisions of title 28 , section 1651 , United States Code. . . . There shall be no appeal or review of an order of the panel denying a motion to transfer for consolidated or coordinated proceedings.

241 Phil Neal, former dean of the University of Chicago School of Law was Executive Secretary of and Consultant to the Coordinating Committee established by Chief Justice Warren to administer the cases. He was also one of the authors of $\S 1407$. Judge Becker was a member of the Coordinating Committee. In re Plumbing Fixture Cases, 298 F. Supp. at 490 n.*.

${ }^{262}$ Multidistrict Litigation: Hearings on S. 3815 Before the Subcomm. on Im- 
mony could be narrowly interpreted to mean that they believed that Van Dusen would govern only in diversity cases transferred under section 1407 or more broadly interpreted to mean that they believed Van Dusen would govern in federal question cases as well, such as in the federal antitrust cases with which they recently had dealt. ${ }^{243}$ In either event, the testimony furnishes no clear legislative history on the particular question whose law of the case doctrine should apply, because the character of the doctrine as substantive or procedural is debatable. ${ }^{\mathbf{2 4 4}}$

Case law under section 1407 bears out that transferee courts typically have applied the substantive law of transferor courts in diversity cases and even in federal questions cases. ${ }^{245}$ As appears more fully below, ${ }^{246}$ the courts involved in section 1407 litigation have applied their own law of the case doctrine, apparently without recognizing that another forum's version of the doctrine might be a more appropriate choice.

The contemplated functioning of section 1407 litigation affirmatively supports the position proposed here. Section 1407 provides for the temporary transfer of civil actions during their pretrial stages, with

provements in Judicial Machinery of the Senate Comm. on the Judiciary, 89th Cong., 2d Sess. 13, 25 (1966), noted in Marcus, supra note 107, at 710 n.200.

24s See Marcus, supra note 107, at 710-11.

244 See supra text accompanying notes 108-44. The following addition to 28 U.S.C. § 1407 was recently proposed:

In order to ensure consistent results, the transferee court shall determine the source of the substantive law. The same substantive law shall be applied to all cases that were transferred to and originally filed in the transferee court, and in making the determination of the appropriate source of substantive law the transferee court shall not be bound by the choice of law rules which the transferor court or courts or the transferee court would otherwise apply in cases governed by State law.

R. Marcus \& E. Sherman, Complex Litigation, Cases and Materials on Advanced Givil Procedure 327 (1985).

Under the letter or spirit of this proposal, a $\S 1407$ court might always choose to apply its own law of the case doctrine. The proposal has not become law, however.

${ }_{245}$ See, e.g., Jayne v. Royal Jordanian Airlines Corp., 502 F. Supp. 848, 851 (S.D.N.Y. 1980) (defendant's amenability to suit is governed by law of the transferor state in a diversity case); Windbourne v. Eastern Air Lines, Inc., 479 F. Supp. 1130, 1142-45 (E.D.N.Y. 1979) (where action was transferred from district court in Louisiana, Louisiana law would govern capacity to sue), rev'd on other grounds, 632 F.2d 219 (2d Cir. 1980); Stirling v. Chemical Bank, 382 F. Supp. 1146, 1150-51 (S.D.N.Y. 1974) ( $\$ 1407$ court applied the law of the transferor forum as to who could maintain an action for damages under $\S 10(\mathrm{~b})$ of the Securities Exchange Act of 1934 and the Securities Act of 1933), affd per curiam, 516 F.2d 1396 (2d Cir. 1975); In re Four Seasons Sec. Laws Litig., 370 F. Supp. 219, 236 (W.D. Okla. 1974) (§ 1407 court applied the law of the transferor court as to what had to be proved to permit recovery under the federal securities laws). In re Data.Gen. Corp. Antitrust Litig., 510 F. Supp. 1220, 1227 (J.P.M.D.L. 1979) ( $\$ 1407$ judge may have to apply the substantive law of more than one state).

${ }^{248}$ See infra notes $266-429$ and accompanying text. 
remand of the transferred actions to the districts in which they began, unless they have terminated while under the control of the section 1407 judge. Despite the fact that more than half of the cases transferred under section 1407 have been disposed of by the section 1407 court, ${ }^{247}$ this legislated scheme arguably favors continuous use of the law of the case doctrine of any ruling court, as to its rulings: it would be both uneconomical and inefficient for the rules governing a case to change repeatedly as the case moved from transferor to transferee court and back, or on to a third court. Even in cases that terminate in the section 1407 court, potential changes in law of the case doctrine and concomitant diseconomies could otherwise occur because of the participation of discovery courts. It must be kept in mind, however, that section 1407 transfer exists for purposes of coordination or consolidation of cases, often many cases. If a section 1407 transferee or other participating court were asked to reconsider various orders of several other courts, it might be faced with the onerous task of ascertaining and applying the law of the case doctrines of any number of state or federal courts. Under these circumstances, the best approach remains presumptive use of the law of the case doctrine of the court whose ruling is challenged. A court in multidistrict litigation, however, should have discretion to use its own, or another single, doctrine when necessary to effectuate fair, efficient, and uniform handling of the cases.

The next question that arises is how, if at all, the content or application of law of the case doctrine ideally should change to reflect the unique qualities of multidistrict litigation. The previously elaborated substance or content of law of the case doctrine for simple litigation ${ }^{248}$ is a suitable starting point for multidistrict litigation as well. The supplemental aspects of law of the case doctrine prescribed above for situations involving a change of judge, transfer, and consolidation will accommodate many of the changes wrought by the multidistricting of a case. ${ }^{249}$ The analysis must be extended farther, however, because application of the doctrine may be affected by the very multidistrict nature of an action. For example, the very facts of transfer and consolidation with other cases under section 1407, after the initial decision of an issue, often will constitute a change in circumstances that warrants reconsideration. Thus, when transferor court rulings are questioned in the section 1407 transferee court or in a discovery court, reconsideration

267 As of June $30,1985,14,489$ actions had been subject to proceedings under 28 U.S.C. $\S 1407$. Of those, 9743 had been terminated by the transferee court. See 1985 AnN. Rep. Director Admin. Off. U.S. Crs. 168.

248 See supra notes 7-66 and accompanying text.

249 See supra notes 67-231 and accompanying text. 
often will be appropriate even for rulings that otherwise should stand. In multidistrict litigation, rulings made after the section 1407 consolidation also may be challenged, and the consolidation does not then constitute a change of circumstances. This Article therefore must illuminate how the statutorily contemplated remand, or further transfer, of a case should affect law of the case principles and their application. Finally, the Article examines how the fact that the challenged ruling was made while a case was a part of section 1407 proceedings should affect the content or application of law of the case doctrine by the court that is the last to consider the case.

The circumstances of section 1407 litigation do not suggest an effort to judge shop for more favorable rulings. The procedures under section 1407 are such that cases can be temporarily transferred and consolidated for pretrial without any party to them having requested such treatment. ${ }^{250}$ Even when a party so moves, she has relatively little influence on the Panel's choice of the multidistrict judge, for there are many other parties who will voice their views. The ultimate decision is the Panel's. In addition, the judge who initially ruled will be unavailable to afford reconsideration unless and until the case is remanded to her. ${ }^{251}$ Depending on the nature of the issue, reconsideration may be necessary long before the time of remand, if it is to be allowed at all.

Consequently, a change in judge should not itself be a significant factor in a section 1407 transferee judge's decision to afford or to deny reconsideration of another's prior ruling. The primary relevance of the change usually will lie in the duplication of effort and concomitant consumption of time that reconsideration by a new judge will entail. Similar practical realities make it highly unlikely, if not impossible, for a party to shop successfully for judges to hear discovery issues, or for the ultimate transferee judge. There might be some possibility of shopping for the remand judge, if she was the transferor judge and if judge shopping occurred when the case began. Nonetheless, the fact of a change of judge generally should not itself be a significant factor in any judge's decision whether to afford reconsideration of another's prior ruling.

The previous remarks on the effects of consolidation on law of the case issues are pertinent to section 1407 litigation as well. ${ }^{252}$ In section 1407 litigation, there is consolidation, or at least coordination, of a number of cases. In theory, the consolidation is for pretrial purposes only. In fact, many cases so coordinated under section 1407 come to be

${ }^{250}$ See 28 U.S.C. § 1407(c)(i). (1982).

${ }^{251}$ Of course, if the ruling judge becomes the $\S 1407$ "transferee" judge, no change of judge will have occurred for certain litigants.

${ }_{282}$ See supra notes 82-89 and accompanying text. 
fully consolidated under Rule $42 .{ }^{253}$

Some judges have expressed the view that law of the case is particularly applicable in section 1407 litigation to avoid constant relitigation of the same issues by the numerous parties involved. ${ }^{254}$ The courts should not lose sight of the fact, however, that for purposes of law of the case doctrine, section 1407 consolidation, like Rule 42 consolidation, does not render rulings in one case also rulings in the other consolidated actions. Due process requires that persons not parties to a particular litigation be afforded their own day in court unless the circumstances warrant a conclusion that they were in privity with the litigants against whom a ruling was made. ${ }^{255}$ Presenting similar claims or defenses, or raising the same legal issues as someone else, has never sufficed for such privity. Recognition of the due process rights of litigants need not cripple the courts in multidistrict litigation, however. Once a section 1407 or other participating judge has ruled on a matter, it will not take her long to dispose of subsequent motions based on the same legal arguments. New parties will figure out quickly which efforts to litigate issues already decided by the judge at the urging of others will be futile. In addition, this problem unavoidably arises only when reconsideration is sought of rulings made prior to section 1407 consolidation. Once the section 1407 consolidation has occurred, the court often can appoint lead and liaison counsel to act on behalf of all the litigants so that such repetition of effort is eliminated. ${ }^{258}$

When a true law of the case problem is presented in section 1407 litigation, the court-be it a discovery court, the section 1407 court, the remand court or the ultimate transferee forum-ought to consider whether reconsideration should be afforded or denied in order to create and maintain horizontal consistency among the cases, to ease administration, and to enhance the efficiency of processing the group of cases as a whole. ${ }^{257}$ The special factors that come into play by virtue of transfer

253 See Trangsrud, Joinder Alternatives in Mass Tort Litigation, 70 CORNEL.L. L. REv. 779, 804-09 (1985) (criticizing the prevailing view that $\S 1407$ courts may try the transferred claims and the fact that such courts repeatedly have transferred cases to themselves for trial and arguing that $\S 1407$ transfers should be only for pretrial purposes); Note, The Judical Panel and the Conduct of Multidistrict Litigation, 87 HARV. L. REV. 1001, 1002 (1974) (recognizing that "[a] pattern of consolidating multidistrict litigation for all purposes has developed through use of section 1407 transfer in combination with other procedural devices to reduce duplicative litigation in the federal courts" and arguing that the JPMDL's control over multidistrict cases should be increased).

254 See, e.g., Philadelphia Hous. Auth. v. American Radiator \& Standard Sanitary Corp., 323 F. Supp. 381, 383 (E.D. Pa. 1970).

258 See supra note 86 and accompanying text.

2se See Manual for Complex Litigation Second $§ 20.22$ (1985).

257 These factors are relevant whether a $\S 1407$ court elects to "coordinate" or to 
also are pertinent in section 1407 situations. A section 1407 transfer, however, will rarely reflect an effort to forum shop that should cause the judge to be on her guard when confronting a law of the case problem. A case may be transferred under section 1407 absent the urging, and even over the objection, of many litigants, and many parties will express views as to which court should be chosen as the transferee forum. The final decision is the Panel's. In the past, when the Panel has perceived forum shopping to be the primary impetus for a motion for section 1407 transfer, it has denied the transfer. ${ }^{258}$ Consequently, the change of judicial district itself ordinarily should not raise barriers to reconsideration, as a means of discouraging such forum shopping.

The points made earlier in this Article concerning the interplay between the competence principle for choice of law as to federal issues and the clearly erroneous exception to law of the case doctrine also have relevance in section 1407 litigation, as do appellate jurisdictional limits. ${ }^{259}$ Similarly, the points made above concerning the propriety of deference to rulings by courts lacking subject matter jurisdiction, personal jurisdiction or proper venue, retain validity. ${ }^{260}$

This Article will next elaborate and illustrate law of the case analysis as applied to the problems that can arise between and among the tribunals hearing multidistrict litigation successively, and sometimes concurrently. It will consider the deference due to commencement court rulings put before the Panel, Panel reconsideration of its own rulings, transferor court rulings in the section 1407 transferee court, transferor and section 1407 transferee court rulings in discovery courts, discovery court rulings in the section 1407 transferee court and elsewhere, section 1407 transferee court reconsideration of its own rulings, section 1407 transferee court rulings put before the Panel, section 1407 transferee court and discovery court rulings in the remand court, and transferor court, section 1407 transferee court and discovery court rulings in the ultimate transferee court.

\footnotetext{
"consolidate" the cases for discovery, whatever may distinguish the two. See In re South Cent. States Bakery Prods. Litig., 433 F. Supp. 1127, 1130 (J.P.M.D.L. 1977) ("coordinate" and "consolidate" denote different judicial functions).

258 See, e.g., In re Motion Picture "Standard Accessories" \& "Pre-Vues" Antitrust Litig., 339 F. Supp. 1278, 1280 (J.P.M.D.L. 1972) (where motion for transfer was not based on factors cognizable under statute motion for transfer was denied).

${ }^{260}$ See supra text accompanying notes 151-68. For an example and a discussion of the ways these issues have arisen in multidistrict litigation, and how they might best be dealt with, see the discussion of the Exterior Siding case, infra notes 282-315 and accompanying text.

${ }^{280}$ See supra text accompanying 189-200.
} 


\section{Panel Reconsideration}

The Panel is empowered to decide only whether, when, and where particular civil actions, or claims therein, should be transferred for coordinated or consolidated pretrial proceedings, and whether and when to remand such transferred actions. ${ }^{261}$ In deciding transfer issues the Panel considers a question that no district court can have ruled upon, for only the Panel is empowered to order section 1407 transfers. ${ }^{262}$ As a result, law of the case doctrine cannot apply to Panel transfer decisions. It is clear that the Panel does not regard itself as precluded by district court decisions not to order transfer for all purposes under 28 U.S.G. $\S \S 1404$ or $1406,{ }^{263}$ or Rule 42 consolidation of cases. ${ }^{264}$ These decisions are sufficiently different from the ones the Panel faces that it has the freedom to reach an independent judgment on the questions raised when section 1407 transfer is contemplated.

The Panel may, of course, reconsider its own decisions. In so doing, it applies its own understanding of law of the case doctrine. The Panel's understanding of the doctrine must be consistent with United States Supreme Court decisions, but the Panel is not governed by the interpretations of any one federal appellate circuit. Because the decisions of the Panel relate only to whether, when, and where to transfer particular civil actions for pretrial, and whether and when to remand them to the courts in which they were commenced, reconsideration normally is available only when warranted by changes in the factual or legal context. ${ }^{285}$

28128 U.S.C. $\S 1407$ (a) (1982). Rule 11 of the Rules of Procedure of the JPMDL spells out the circumstances under which the JPMDL ordinarily will, and will not, remand, and the circumstances that will trigger its consideration of remand. In many cases, the JPMDL has disavowed power to enter orders concerning matters other than transfer and remand. See, e.g., In re Air Grash Disaster, 476 F. Supp. 445, 451 (J.P.M.D.L. 1979) (no authority to notify potential litigants of the proceedings); In re Westinghouse Elec. Corp. Uranium Contract Litig., 436 F. Supp. 990 (J.P.M.D.L. 1977) (no authority to order expedited discovery as an alternative to transfer); In re Molinaro/Catanzaro Patent Litig., 402 F. Supp. 1404, 1406 (J.P.M.D.L. 1975) ("The scope of the coordinated or consolidated pretrial proceedings and the extent to which discovery is permitted are matters exclusively within the control of the transferee judge.").

${ }_{282}$ See 28 U.S.C. $§ 1407$ (a) (1982).

${ }^{203}$ See, e.g., In re American Fin. Corp. Litig., 434 F. Supp. 1232, 1234 (J.P.M.D.L. 1977) and cases cited therein (referring to the different considerations underlying the various transfer statutes).

${ }^{204}$ See, e.g., In re South Cent. States Bakery Prods. Antitrust Litig., 433 F. Supp. 1127, 1129-30 (J.P.M.D.L. 1977).

${ }_{285}$ But of. In re Plumbing Fixtures Litig., 342 F. Supp. 756 (J.P.M.D.L. 1972) (The JPMDL initially had postponed the transfer decision to allow plaintiff North Carolina to get a ruling from the district judge on plaintiff's standing to sue. On reconsideration, it decided to order $\S 1407$ transfer without further delay, in the belief that 


\section{Transferor Court Rulings in the Section 1407 Transferee Court}

The largest number of reported law of the case problems involve transferor court rulings challenged in the section 1407 transferee court. ${ }^{268}$ The rulings in question fall into several categories.

One group of decisions involves jurisdictional matters. In In re Long Distance Communication Litigation ${ }^{267}$ actions had been brought alleging that long distance telephone carriers had violated the Communications Act of $1934^{288}$ and common law by charging consumer plaintiffs for long distance calls that never were completed and by failing to advise them of that practice. ${ }^{268}$ A New York transferor district judge had held that plaintiffs had pleaded federal common law claims that did not need to be sent to the Federal Communications Commission ("FCG") pursuant to the doctrine of primary jurisdiction. ${ }^{270} \mathrm{His}$ ruling conflicted with the rulings of other transferor judges and courts, including the court that became the section 1407 transferee court. As a result, a defendant sought from the section 1407 court reconsideration of the partial denial of its motion to dismiss the complaint.

The section 1407 court decided to reconsider and alter the ruling in question. It relied on circumstances that it characterized as falling within the well-recognized exception to law of the case doctrine for "changes of fact or circumstances," including the fundamental change in the posture of the case wrought by the section 1407 transfer. ${ }^{271}$ In particular, the court emphasized an unforeseeable intervening FCG decision clearly indicating that the FCC would regulate the disclosure to customers of the carriers' billing practices. This, it found, significantly undercut the argument that plaintiffs' common law claims were not within the primary jurisdiction of the FGC and led to the risk of irreconcilable results if the court did not dismiss. The court found that the FCC decision therefore justified reconsideration and strengthened the

the $\S 1407$ transferee judge would have to apply North Carolina's reading of the pertinent federal law to decide the standing issue. But see infra note 394.)

${ }^{268}$ This is what my research revealed; see supra note 176.

267612 F. Supp. 892 (E.D. Mich. 1985).

26847 U.S.G. § 201(b) (1982); 47 U.S.C. § 207 (1982).

${ }^{269}$ In re Long Distance Telecommunications Litig., 612 F. Supp. at 894.

$270 I d$. at 900-01. Primary jurisdiction is the doctrine that determines whether a court or an agency should make the initial decision of certain questions. "[A] court normally should not act upon subject matter that is peculiarly within the agency's specialized field without taking into account what the agency has to offer, for otherwise parties who are subject to the agency's continuous regulation may become the victims of uncoordinated and conflicting requirements." K. Davis, AdMinistrative LaW TEXT $\S 19.01$, at 374 (1972).

${ }^{271}$ In $r e$ Long Distance Telecommunications Litig., 612 F. Supp. at 902-03. 
argument for dismissal. ${ }^{272}$ In light of the inconsistent prior rulings of the transferor courts, the court further invoked the basic purpose of multidistrict litigation to achieve consistent rulings on common issues, this being a common issue "at the very heart of these controversies." The court pointed out that the judge whose ruling was at issue himself had recognized that there were "substantial grounds for differences of opinion," although the relevance of this fact was left to be inferred. ${ }^{274}$ Finally, the court found that the usual rationale for applying law of the case doctrine was absent, reasoning that the purpose is to protect courts, that is, new judges, from the burdens of readdressing issues previously decided by other judges. Here, however, because the section 1407 judge already had considered the issue, invocation of the doctrine would not conserve judicial resources. ${ }^{275}$ Plaintiff's common law claims thus were dismissed.

The court's reasoning seems cogent and persuasive, and its result correct. It is consistent with the courts' and commentators' view that matters of jurisdiction are peculiarly suitable for reconsideration. ${ }^{276} \mathrm{Be}-$ yond that, the opinion is interesting both for what it does and does not say. The court failed to consider whether any choice of law question was presented as to whose law of the case doctrine was applicable. It presumably assumed either that the Sixth Circuit's law of the case doctrine applied ${ }^{277}$ or that there were no inter-circuit differences. ${ }^{278}$ This Article suggests that the transferee judge should have applied the law of the case doctrine prevailing in the New York transferor court, at least if the two doctrines were in conflict. On these facts, both doctrines would have led to the same result: reconsideration. The decision also is interesting in its inclusion of the section 1407 transfer itself as a change of

272 Id.

273 Id. at 903.

274 Id. at 901 and 903 . Judge Glasser had certified his decision for immediate appeal under 28 U.S.C. § 1292(b). The Second Circuit refused to hear the appeal, however. Id. at 901-02. Perhaps the transferee court viewed Judge Glasser's actions as evidence that he himself would have afforded reconsideration, had the case still been before him.

278 Id. at 903.

276 See supra notes 19-20 and accompanying text.

277 The court cited two Sixth Circuit decisions: In re Upjohn Co. Antibiotic Cleocin Prods. Liab. Litig., 664 F.2d 114 (6th Cir. 1981) and In re United States Steel Corp., 479 F.2d 489 (6th Cir.), cert. denied, 414 U.S. 859 (1973). See In re Long Distance Telecommunications Litig., 612 F. Supp. 892, 902 (E.D. Mich. 1985).

278 The court also cited decisions of other appellate circuits: In re Multi-Piece Rim Prods. Liab. Litig., 653 F.2d 671 (D.C. Cir. 1981); In re Exterior Siding \& Aluminum Coil Antitrust Litig., 696 F.2d 613 (8th Cir. 1982), vacated en banc on other grounds by an equally divided court, 705 F.2d 980 (8th Cir.), cert. denied, 464 U.S. 866 (1983). See In re Long Distance Telecommunications Litig., 612 F. Supp. at 902. 
circumstance warranting reconsideration. The judge was correct to see that an aberrational ruling as to the sufficiency of plaintiffs' complaint in one of several consolidated cases would tend to undermine the purposes of the section 1407 consolidation. The ruling of the New York transferor court, sustaining plaintiff's common law claims, however, could have coexisted with the contrary rulings of the other participating courts. It did not impose contradictory obligations on any party or make the multidistrict proceeding unmanageable. If no useful purpose would have been served by retaining the claim in the section 1407 court, the Panel could have remanded it. Yet, in light of the intervening FGC decision, the section 1407 court's reconsideration and "reversal" were undoubtedly correct. Certainly, the transferee judge had little reason to be concerned that on remand the transferor court would reinstate its original ruling. The intervening FCC decision made that highly unlikely. ${ }^{278}$

In another group of cases, transferee courts are faced with deciding whether to reconsider rulings concerning the formal sufficiency of pleadings. As to unimportant matters, such as the detail required in a pleading, ordinarily law of the case will be invoked, and the orders of the transferor court enforced. ${ }^{280}$ Yet if a transferee judge wanted to have the pleadings consolidated for pretrial purposes, she certainly would have the power to so order. ${ }^{281}$ In that situation, the goal of uniformity in the pleadings would outweigh the application of law of the case doctrine.

A third category of rulings that arise for reconsideration involves class certification. ${ }^{282}$ The leading case in this area is In re Exterior

279 Another case involving a $\S 1407$ court's handling of a jurisdictional ruling is Astarte Shipping Co. v. Allied Steel \& Export Serv., 767 F.2d 86, 87 (5th Cir. 1985) (In transferor court certain property of the defendants, owners of a vessel, had been attached pursuant to an admiralty rule; the attachment was appealed to the court of appeals for the $\S 1407$ transferee court, which said in dictum, "The transferee district court has the power and the obligation to modify or rescind any orders in effect in the transferred case which it concludes are incorrect.").

${ }^{280}$ See In re Penn Central Sec. Litig. (Abernathy v. Great S.W. Corp.), 62 F.R.D. 181, 187 (E.D. Pa. 1974) (although suggesting that it thought unnecessary the pleading of stock certificate numbers bought and sold by plaintiffs in a securities fraud case, $\S 1407$ court enforced transferor court's order requiring such pleading). One finds no discussion of such fine points as whose doctrine is being applied.

${ }^{281}$ See, e.g., Katz v. Realty Equities Corp., 521 F.2d 1354, 1358-59 (2d Cir. 1975); In re Equity Funding Corp. of Am. Sec. Litig., 416 F. Supp. 161, 176 (C.D. Cal. 1976), affd, 603 F.2d 1353 (9th Gir. 1979).

${ }^{282}$ The JPMDL prefers class action determinations to be made in the first instance by $\S 1407$ transferee courts as the best way to insure the absence of conflict in such determinations and to promote judicial efficiency. See, e.g., In re Piper Aircraft Distrib. Sys. Antitrust Litig., 405 F. Supp. 1402, 1403-04 (J.P.M.D.L. 1975); In re Plumbing Fixtures, 311 F. Supp. 349, 351 (J.P.M.D.L. 1970), citing In re Plumbing 
Siding $\mathcal{E}^{9}$ Aluminum Coil Antitrust Litigation. ${ }^{283}$ In a Sherman Act ${ }^{284}$ case alleging a conspiracy to eliminate competition and to fix artificially high prices for certain aluminum products, ${ }^{285}$ a Minnesota district judge had twice denied class certification and had refused to reconsider his second decision. The case was then consolidated for pretrial with other similar actions. Judge Weiner of the Eastern District of Pennsylvania, sitting by designation in the Minnesota district court, ${ }^{288}$ was named the section 1407 judge. He granted plaintiffs' motion for class certification. In response to defense arguments that he had failed to accord substantial weight to the aforementioned, pre-consolidation decisions, Judge Weiner concluded, "It is clear from the Act itself that class certification determinations are to be resolved by the transferee court free from the influence of any initial determinations of transferor courts."287 Judge Weiner also noted that the exercise of individual judgment was a fundamental part of the exercise of his discretionary powers. ${ }^{288}$ Exercising the broad discretion available under Rule 23, ${ }^{289}$ he differed as to the result with his colleague, and thus reaffirmed the class certification, stating, "[I]t was within the discretion of this court alone, as the transferee court, to grant certification." 280

Fixtures, 298 F. Supp. 484, 492-96 (J.P.M.D.L. 1968). The question here is the effect of law of the case doctrine on the transferee court when prior rulings on the class issue have been made.

28s In re Exterior Siding \& Aluminum Coil Litig., 538 F. Supp. 45 (D. Minn. 1982) [hereinafter Exterior Siding I], mandamus granted sub nom. Exterior Siding \& Aluminum Coil Litig., 696 F.2d 613 (8th Gir. 1982) [hereinafter Exterior Siding II], vacated en banc by equally divided court, 705 F.2d 980 (8th Cir.) [hereinafter Exterior Siding III], cert. denied, 464 U.S. 866 (1983).

284 15 U.S.C. $\S \S 1,2$ (1982).

${ }^{285}$ Exterior Siding I, 538 F. Supp. at 46-47. After the initial denial, plaintiffs had attempted to narrow the class definition to eliminate some of the problems with a class action. The judge held that Rule 23's class certification requirements still were not met. See Exterior Siding II, 696 F.2d at 614-15.

${ }^{286}$ Under 28 U.S.C. \$292(d) (1982), the Chief Justice of the United States may designate and temporarily assign a district judge of one circuit for service in another circuit's district court upon presentation of a certificate of necessity by the chief judge or circuit justice of the circuit in need. A district (or circuit) judge also may be designated and assigned to a $\S 1407$ transferee court upon request of the JPMDL. 28 U.S.C. $\S 1407$ (b) (1982). With a very few exceptions not applicable here, a judge so designated and assigned has all the powers of a judge of the court to which he has been assigned. 28 U.S.C. § 296 (1982); see 28 U.S.C. § 132(b) (1982).

${ }^{287}$ Exterior Siding I, 538 F.Supp. 45, 47 (D. Minn. 1982).

288 Id. at 48.

289 FED. R. Crv. P. 23. The district court is directed to "determine by order" whether a class action is to be maintained under the flexible standards set forth in Rules 23(a) and (b). See infra note 291; see also In re Cessna Aircraft Dist. Antitrust Litig., 518 F.2d 213, 215 (8th Cir. 1975) (district court has broad discretion).

290 See Exterior Siding I, 538 F. Supp. at 49. The court also refused to certify his class action determination for interlocutory appeal under 28 U.S.G. $\S 1292$ (b). Id. at 48-49. 
Defendants then petitioned for a writ of mandamus ordering Judge Weiner to vacate his class certification order. ${ }^{201}$ Initially, a panel of the Court of Appeals for the Eighth Gircuit held that Judge Weiner had so exceeded his discretion as to justify the grant of mandamus. ${ }^{202}$ The panel agreed that a section 1407 transferee court is and must be free to alter or overturn conflicting orders of transferor courts to effectuate the purposes of section $1407 . .^{293}$ It further acknowledged that class certification decisions are by nature conditional and subject to judicial revision. ${ }^{284}$ It emphasized, however, that under the doctrine of law of the case, a judge should not, without good cause, overrule the decisions of a prior judge in the same case ${ }^{295}$ and that Rule 23 contemplates that a judge should not alter a previous class certification decision unless fuller development of the facts or a change in the facts calls for such action. ${ }^{296}$ The court also found it significant (although it did not explain why) that the two district judges involved were sitting as judges of the same court. ${ }^{287}$ Here, the class definition proposed to the section 1407 judge was essentially identical to that first presented to the original judge, the plaintiffs in the newly consolidated cases having sought overlapping class certification on complaints that were virtual "carbon copies" of the complaint before the original judge; the underlying facts had not changed (Judge Weiner made no new factual findings and did not base his decision on changed circumstances); and the original judge's opinions denying class action status were well-reasoned, painstaking, and detailed. ${ }^{208}$ All of these factors argued against the propriety of reconsideration by Judge Weiner.

The Eighth Gircuit panel further supported its conclusion that the section 1407 judge had so exceeded his discretion as to make mandamus appropriate by asserting that the "Panel [the JPMDL] contemplated that Judge Weiner would give consideration to Judge Alsop's prior orders." ${ }^{298}$ This the court apparently inferred from the Panel's selection

${ }^{291}$ Exterior Siding II, 696 F.2d 613, 614 (8th Cir. 1982).

292 Id. at 615.

${ }^{203}$ Id. at 616.

204 See FED. R. CIV. P. 23(c)(1). ("[T] he court shall determine by order whether [an action] is to be so maintained [as a class action]. An order under this subdivision may be conditional, and may be altered or amended before the decision on the merits.").

28s Exterior Siding $I I, 696$ F.2d at 616. The court cited the value of law of the case doctrine in securing uniformity of decision and discouraging repeated litigation of the same question. Id.

${ }^{206}$ Id. at 618, citing FED. R. Crv. P. 23(c)(1) advisory committee's note (1966); see infra note 298.

${ }^{297}$ Exterior Siding II, 696 F.2d 613, 617-18 (8th Cir. 1982).

298 Id. at $615-16,618$.

${ }^{298}$ Id. at 617 (emphasis added). 
of the District Court of Minnesota as the forum where suit was most advanced, rulings having been made there on a number of matters including class certification motions. ${ }^{300}$ The Eighth Gircuit panel concluded that

[t]o have the transferee court, though sitting with a different judge, make a different ruling only because the second judge "differed as to the result," and considered the issue to be within his discretion alone, so exceeds the sphere of that court's discretionary power that it is a usurpation of power. Mandamus is the only possible and appropriate remedy. ${ }^{301}$

Three months later, having reheard the case en banc, the Eighth Gircuit, by an equally divided court, issued a one sentence per curiam denial of the petition for writ of mandamus. ${ }^{302}$ Among the controlling four was the dissenter from the panel decision, Judge Arnold. Assuming that his views are representative of the views of those who joined him, the denial of mandamus may have turned on the impropriety of granting mandamus as to any ruling concerning class certification..$^{303}$ Judge Arnold also believed, however, that Judge Weiner's conduct, in particular, did not constitute a usurpation of power warranting the issuance of mandamus. ${ }^{304}$

Although the conflicting mandamus rulings pose interesting issues, the concern here is not with whether mandamus is ever appropriate as to a class certification decision, but with what law of the ease doctrine required or should have required of Judge Weiner. First, the Eighth Circuit panel failed to appreciate that the law of the case issue arose only in the case that had been before Judge Alsop and not in the other

300 Id. at 614 n.3 and 617.

sol Id. at 618. The court added as a caveat that its holding was limited to the situation "where a district court is made a transferee court, and in a later decision reverses its position simply because the second judge differs as to the result with the predecessor judge, and without a change of circumstances." Id. at 618.

${ }^{202}$ Exterior Siding III, 705 F.2d 980 (8th Cir. 1983) (per curiam). The short dissenting opinion favored mandamus on the grounds that the transferee judge had ignored the opinions of the transferor judge and because the class certified was without record support. Id. (Heaney, J., dissenting).

203 See Exterior Siding II, 696 F.2d 613, 618-19 (8th Cir. 1982) (Arnold, J., dissenting). There is at present a recommendation by the Special Committee on Class Action Improvements of the American Bar Association Section of Litigation to amend the Judicial Code to permit appeals from the grant or denial of certification orders, provided that the application is made to the appeals court within 10 days after entry of the order. The appeals court would have full discretion to grant or deny such an interlocutory appeal. Gruenberger, Plans for Class-Action Reform, Nat'l L.J., July 8, 1985 , at 32,33 , cols. 3-4.

${ }^{206}$ Exterior Siding II, 696 F.2d at 620-21. Aspects of Judge Arnold's dissent are noted below; see infra text accompanying note 302 . 
actions that had been consolidated with it for pretrial and sent to Judge Weiner. Thus, the parties to only those other actions had a right to be heard by Judge Weiner on the propriety of class action treatment. ${ }^{305}$ As to those other actions, Judge Alsop's ruling was due some consideration under stare decisis, but it certainly was not a usurpation of power for Judge Weiner to decline to follow Judge Alsop's ruling. ${ }^{308}$ As to the "case of origin," it is noteworthy that no choice of law quandary was presented by the facts of this case: both the transferor court and the section 1407 transferee court were Minnesota district courts. ${ }^{307}$

With respect to the content of the law applied, the Eighth Circuit panel took a rather narrow view of the circumstances under which Rule 23 contemplates that a change of decision concerning class treatment may be made. ${ }^{808}$ Moreover, the Eighth Circuit panel failed or refused to consider that the section 1407 consolidation subsequent to Judge Alsop's orders could constitute both a fuller development of, or a change in, the facts pertinent to a class action determination, within the meaning of the Advisory Committee Notes to Rule 23(c)(1), ${ }^{309}$ as well as a change in circumstances justifying reconsideration rather than adherence to law of the case. ${ }^{\mathbf{3 1 0}}$ Contrary to the Eighth Circuit's position, there is substantial reason to believe that the Panel contemplates that section 1407 courts will review and may revise class action decisions of

${ }^{305}$ See supra text accompanying notes 84-86; accord Exterior Siding II, 696 F.2d at 620 (Arnold, J., dissenting).

${ }^{300}$ See supra text accompanying note 87; $c f$. In re Staff Mortgage \& Inv. Corp. (Greiner v. Wilke), 625 F.2d 281, 282-83 (9th Gir. 1980) (stare decisis, not law of the case, applied to two proceedings involving the same bankrupt, but different plaintiffs, and nearly identical issues).

${ }^{807}$ Because both the case of origin and the $\S 1407$ consolidated actions were in Minnesota federal district courts, there would be no question that the law of the case doctrine as understood in that court and in the Eighth Gircuit would control, particularly if the doctrine is recognized properly to be limited to proposed reconsideration of rulings made in the case of origin. As a result, there also were no law of the case complications deriving from appellate jurisdictional limits on the Eighth Circuit.

sos See Exterior Siding II, 696 F.2d at 613, 620 (8th Cir. 1982) (Arnold, J., dissenting); $c f$. Zenith Laboratories, Inc. v. Carter-Wallace, Inc., 530 F.2d 508, 511-12 (3d Cir.) (reevaluation of class certification by successor district judge was warranted when a prior action had been settled, plaintiff had added counts to the complaint and second judge believed that class certification might have been based on an erroneous assumption), cert. denied, 429 U.S. 828 (1976); 3B MOORE's FEDERAL PRACTICE, supra note 7 , II 23.50 , at 23-432 to 23-436.

300 The Advisory Committee Notes state: "A determination once made can be altered or amended before the decision on the merits if, upon fuller development of the facts, the original determination appears unsound." FED. R. Crv. P. (c)(1) advisory committce note (1966).

${ }^{310}$ See In re Long Distance Communications Litig., 612 F. Supp. 892 (E.D. Mich. 1985), discussed supra text accompanying notes 264-75. The Eighth Circuit panel did recognize "changed circumstances" as an exception to law of the case doctrine. Exterior Siding II, 696 F.2d at 617. 
transferor courts. It has said,

In the case of class action determinations made by the transferor court prior to transfer, the provisions of Rule 23 apply, permitting the transferee court to determine the class action questions and to review and revise any class action order as in its sound judicial discretion is desirable or necessary in the interests of justice. ${ }^{311}$

Judge Weiner was a member of the Panel at the time of his decision in the Exterior Siding case; he presumably knew the Panel's position better than the Eighth Circuit court did. ${ }^{312}$ Judge Arnold, in dissent, suggested quite persuasively how the consolidation of three additional cases involving allegedly conspiratorial activities in different parts of the country, and the addition of named corporate class representatives who could cure earlier doubts about whether the proposed class would receive adequate representation, might well have created a change in circumstances that justified reconsideration of the class certification question. ${ }^{\mathbf{3 1 3}}$ Certainly, if Judge Weiner believed that a class should be certified in the actions from outside Minnesota sent to him by the Panel, it would have undermined the purposes of section 1407 for him to certify a class in them, while adhering to Judge Alsop's refusal to certify as the law of the Minnesota cases.

Neither the fact that Judge Weiner was sitting as a judge of the same court as Judge Alsop nor the discretionary nature of class action determinations weakens these arguments. Indeed, the fact that Judge Weiner was sitting as a judge of the Minnesota court strengthens the case for his certifying a class as he deemed appropriate: if there were a "remand" of the Minnesota case, it would make most sense that it be a remand to Judge Weiner, continuing to sit as a judge of that court, in light of the knowledge he would have attained as a result of handling the pretrial proceedings. Even if a remand might go to Judge Alsop there is little reason to believe that he would attempt to undo Judge Weiner's decision. Finally, even if Judge Alsop's refusal to certify a class was not an abuse of discretion, both the tentative nature of such a

811 In re Plumbing Fixture Cases, 298 F. Supp. 484, 496 (J.P.M.D.L. 1968) (6-1 en banc decision) (cited by Arnold, J., in dissent in Exterior Siding II, 696 F.2d at 620-21); see In re Antibiotic Drugs, 295 F. Supp. 1402, 1404 (J.M.P.D.L. 1968) (to grant request that $\S 1407$ transferee court be precluded from making class action determinations would deny it the power to resolve the potential conflict in multidistrict class action determinations).

${ }^{312}$ See Exterior Siding II, 696 F.2d 613, 620 (8th Cir. 1982) (Arnold, J., dissenting).

313 Exterior Siding II, 696 F.2d at 620 (Arnold, J., dissenting). Judge Alsop's reasons for refusing to allow class action treatment are sketched in 696 F.2d at 615 . 
ruling and the change of circumstances wrought by the section 1407 consolidation justified reconsideration by the section 1407 judge. For all of these reasons, the Eighth Circuit panel exaggerated the "unseemliness" 14 of Judge Weiner's "reversal" of Judge Alsop, and seems to have erred in concluding that the section 1407 judge was guilty of a usurpation of power justifying mandamus. The decision of the Eighth Circuit en banc, denying mandamus, was correct. ${ }^{\mathbf{3 1 5}}$

Before leaving the case, it is interesting to consider the potential effects of appellate jurisdictional limits and the competence principle in a case similar to Exterior Siding, but where the transferor and section 1407 transferee district courts sit in different federal circuits. If the transferee Eighth Circuit concluded that it had jurisdiction to review the denial of class action certification by an out-of-circuit transferor court (either by interlocutory appeal or after final judgment) and its district court knew that the class determination would be reviewed under more liberal Eighth Circuit precedent, the district court would have to reconsider and perhaps modify or "reverse" the initial ruling in order to avoid reversal. An exception to law of the case would be held to apply. If the transferee court would test the class action decision against the Rule 23 precedents of the transferor court, it is less likely that the exceptions for clearly erroneous decisions or clear abuses of discretion would require reconsideration. On the other hand, if the Eighth Gircuit concluded that it lacked jurisdiction to review the transferor court's denial of class certification, appellate review of that decision could be obtained from the Eighth Circuit only if the transferee district court found an exception to law of the case to be applicable and itself reconsidered the question. Once again, the choice of transferor or transferee federal law on class actions would influence the likelihood that the initial ruling would be held clearly erroneous or a clear abuse of discretion.

A final category of rulings that may be afforded reconsideration by transferee courts involves rulings on discovery issues, including the propriety of protective orders. Before section 1407 transfer, transferor courts often have ruled on discovery issues ${ }^{\mathbf{3 1 6}}$ and on motions for pro-

314 Exterior Siding II, 696 F.2d at 621 (Amold, J., dissenting).

315 See Exterior Siding III, 705 F.2d 980 (8th Cir. 1983); see also In re Master Key Antitrust Litig., 70 F.R.D. 23, 26 (D. Conn. 1975) (adhering to prior ruling rejecting the "pass-on" defense as applied to most of the issues presented; adhering to the earlier certification of plaintiff classes, made by a transferor judge, although addressing defendants' objections thereto on their merits), appeal dismissed, 528 F.2d 5 (2d Cir. 1975).

s16 Discovery is governed by FED. R. Grv. P. 26-37. 
tective orders. ${ }^{312}$ In recent years, questions have arisen as to the deference due such rulings by section 1407 transferee courts. The leading case in this area is In re Upjohn Co. Antibiotic Cleocin Products Liability Litigation. ${ }^{318}$ The underlying litigation concerned products liability claims by users of a particular antibiotic that allegedly produced harmful side effects. ${ }^{319}$ Two of the transferor courts had entered protective orders that prevented plaintiffs from revealing to outsiders, or using outside their own litigation, the materials they gained in discovery..$^{\mathbf{3 2 0}}$ After the Panel transferred ten cases to Judge Kennedy of the Eastern District of Michigan, certain plaintiffs restricted by a protective order moved to vacate it, in order to allow discovered materials to be used in all the section 1407 consolidated cases. $^{321}$ Other plaintiffs' counsel sought to have the challenged protective orders vacated also insofar as they prohibited the dissemination of discovery to litigants not parties to the multidistrict litigation. ${ }^{322}$ Upjohn did not press any objection to free exchange of discovered information within the multidistrict litigation, but wanted a protective order to prevent transmission of such information to parties and counsel in independent state court cases. ${ }^{323}$

Judge Kennedy concluded that plaintiffs' motion to vacate the transferor courts' protective orders should be granted and that Upjohn's motion for a protective order should be denied. ${ }^{\mathbf{2 2 4}}$ On a motion for re-

${ }^{317}$ Protective orders of various kinds are available under FED. R. Grv. P. 26(c), upon motion of a party or person from whom discovery is sought, for good cause shown, to protect the movant from annoyance, embarrassment, oppression, or undue burden or expense.

${ }^{318} 664$ F.2d 114 (6th Cir. 1981) [hereinafter Upjohn II].

319 Id. at 115-16.

$320 I d$. at 116.

s21 Id.

sas Id.

s2s In re Upjohn Co. Antibiotic Cleocin Prod. Liab. Litig., 81 F.R.D. 482, 483, 486 (E.D. Mich. 1979) [hereinafter Upjohn I].

324 Id. at 484-86. Basically, the court reasoned that one of the purposes of multidistrict litigation is to promote the sharing of discovery within the consolidated cases and that nothing improper had occurred that would require a protective order. Id. at 484. The court also believed that first amendment concerns required heightened scrutiny of such protective orders. See id. at 485-86. The Supreme Court since has held otherwise. Seattle Times Co. v. Rhinehart, 467 U.S. 20 (1984). So far as dissemination to litigants with independent state court cases was concerned, the judge found that to treat those litigants differently would create an unintended distinction based on citizenship. Upjohn I, 81 F.R.D. at 484. Moreover, the multidistrict plaintiffs had an interest in being able to exchange information with state court litigants. The court found no violation of defendant's rights in such an exchange. Id. at 484. This decision avoided the problems of policing communication to state court participants, and avoided wasteful duplication of discovery. Upjohn's opposition presumably was based on hopes of keeping damaging information from at least some plaintiffs. See R. MaRcus \& E. SHERMAN, supra note 244 , at 78 . Judge Kennedy did, however, establish mandatory procedures governing the release of information to parties in non-multidistrict cases, so 
hearing, Upjohn argued that the decision was inconsistent with law of the case doctrine. Judge Kennedy adhered to her decisions, noting that exceptions to that doctrine apply in multidistrict litigation, that the conduct of discovery was exclusively within her control as the transferee judge, and that it was her duty to control discovery in the consolidated cases so as to avoid the pretrial chaos that could exist as a result of conflicting prior rulings. ${ }^{325}$ On appeal, Upjohn continued to urge that the section 1407 court had erred in even entertaining plaintiffs' motion to vacate completely the pre-transfer orders. ${ }^{326}$ The Court of Appeals for the Sixth Gircuit first made Upjohn's case:

There is, at first blush at least, some arguable merit in the claim that it is really none of the transferee court's business that the transferor court prohibited access to the discovery information by parties outside the multidistrict litigation. After all, the Panel's interest in consolidating discovery is to assist the parties to the cases so transferred. Neither it nor the transferee judge, nor indeed a plaintiff, has any particular obligation to act as Good Samaritan to other parties in other litigation not subject to the order of transfer. It is also true that the transferor court must ultimately be responsible for the final resolution of the dispute upon remand, and might seem to be better positioned to foresee and thus avoid the possible abuse of the discovery by its dissemination to outsiders. It can also be said that there is something unseemly in allowing plaintiffs to relitigate an issue which has already been fairly and fully heard in another court, even more in permitting one judge to overrule another in a matter in which each would seem to have stood on an equal footing. ${ }^{327}$

The court then rejected these arguments. It acknowledged the power of a district court to modify or vacate a protective order, a power that passes to section 1407 transferee judges, and found no breach of comity or offense to a transferor court in the exercise of such power. ${ }^{328}$

that she could protect against any abuses. Upjohn I, 81 F.R.D. at 485 . In addition, she invited Upjohn to seek protective orders in the state court proceedings if it believed it needed protection there. Id. at 484.

${ }^{8 s 5}$ Upjohn I, 81 F.R.D. at 486-87 (statement of Kennedy, C.J., on denial of rehearing),

sa6 Upjohn II, 664 F.2d 114, 117 (6th Gir. 1981).

287 Id.

${ }^{228} I d$. at $118,120$. 
The court continued:

Any transferor court is bound to recognize that the duties of a transferee judge include the responsibility to harmonize the activities relating to discovery in cases which . . . come to it ... in widely variant postures of preparedness. . . . [N]o thoughtful judge will begrudge another's efforts to achieve this object of the Act. ${ }^{329}$

In this case, for instance, the existence of protective orders in some cases, but not others, inevitably would have created difficulties in tracing the source of information conveyed to litigants outside the multidistrict proceedings and in determining whether counsel could be bound by protective orders entered in litigation in which they had not participated. $^{\text {8s0 }}$ The appellate court further opined that even when there is no conflict in transferor court rulings of which parties seek reconsideration, the section 1407 court pays sufficient deference as long as it ponders the reasons that may have prompted transferor courts' actions. ${ }^{331}$ It concluded that law of the case did not require adherence to the protective orders entered in some of the transferred cases, and questioned whether the doctrine was a proper concept in this context. ${ }^{\mathbf{3 3 2}}$

Judge Kennedy and the Sixth Circuit recognized in Upjohn that the protective orders were the law only in the cases in which they were entered, and that problems of fundamental fairness would be created by any automatic extension of these orders to other components of the multidistrict proceeding. But what one does not find in either Judge Kennedy's or the Sixth Circuit's opinion is any discussion of whose law of the case doctrine applied. These courts, as have others, seem to have assumed without analysis that their own law of the case notions governed, despite the fact that extracircuit decisions were "on the chopping block," and arose in cases in federal court under diversity jurisdiction. As explained earlier, ${ }^{833}$ this Article takes the position that, in cases of conflict, a transferee court ordinarily should apply the law of the case doctrine that would be applied by the transferor court. The section

s20 Id. at 118.

sso Id. at 119.

831 Id. at $118-19$.

3s2 Id. at 120. The court correctly distinguished a multidistrict law of the case precedent, Philadelphia Hous. Auth. v. American Radiator \& Standard Sanitary Corp., 323 F. Supp. 381 (E.D. $\mathrm{Pa}$. 1970), as involving rulings by successive judges sitting as the $\S 1407$ transferee court, acting on dispositive legal issues. Upjohn II, 664 F.2d 114, 119 (6th Cir. 1981). See infra text accompanying notes 399-40. It also noted that the JPMDL repeatedly had cited Judge Kennedy's decision with approval. Upjohn II, 664 F.2d at 120 .

sss See supra notes $132-44$ and accompanying text. 
1407 judge in Upjohn was faced with protective orders that had been entered by only two courts, the courts of the Eastern District of Louisiana and the District of South Carolina. Consequently, the burden of ascertaining and applying the law of the case doctrines prevailing in those courts would not have been unduly burdensome. At least in theory, however, the doctrine of the Fourth Circuit might have permitted reconsideration and that of the Fifth Circuit prohibited it. ${ }^{334}$ If that were the fact, then to avoid all the problems that a lack of uniformity in the protective orders would generate, Judge Kennedy ought to have had discretion to apply to all of the challenged rulings the doctrine of one of the transferor courts or that of the section 1407 transferee court.

When the content of the applicable doctrine is considered, it is clear that both Judge Kennedy and the Sixth Circuit understood that the inherently tentative nature of protective orders made them subject to reconsideration. They implicitly agreed with the position taken here that even discretionary decisions may properly be reconsidered and changed in appropriate circumstances. They also clearly appreciated that, after a section 1407 consolidation or coordination, transferor court orders should not be adhered to without considering both their effects on the other cases in the multidistrict proceeding and their continuing value in the case of origin. The courts acted appropriately upon their recognitions that the transferee judge must have authority over protective orders and that the section 1407 purpose of streamlining discovery would have been obstructed by adherence to the protective orders. The section 1407 court might even have had to order some discovery redone if information had been uncovered only in cases where a protective order was in force. ${ }^{385}$ As the courts knew, maintenance of protective orders in only a few of the consolidated cases would have been of little or no use. In sum, Judge Kennedy and the Sixth Circuit did a sensitive and intelligent job of adapting law of the case principles to the special circumstances of multidistrict litigation. ${ }^{\mathbf{3 8}}$

ss4 See supra notes 56-62 and accompanying text.

sas R. MARcus \& E. SHERMAN, supra note 244, at 77.

3s6 When cases have been removed to federal court from state court, the state court already may have made rulings whose effect as law of the case should be considered. Removal is governed by 28 U.S.C. $\$ \S 1441-1451$ (1982). The petition for removal must be filed within 30 days after the receipt by defendant of the pleading or amended pleading from which it first appears that the case is removable, or within 30 days of the service of summons on defendant if the initial pleading states a removable case but the initial pleading is not required to be served on the defendant. 28 U.S.C. $\S 1446$ (b) (1982). (Particularly when a case becomes removable by virtue of an amended pleading, the state trial court may have made rulings by the time of the removal petition.) Federal courts do apply law of the case doctrine to such state court rulings. See Quinn v. Aetna Life \& Casualty Co., 616 F.2d 38, 40-41 (2d Cir. 1980) (under Second Circuit's discretionary law of the case doctrine, federal judge was correct to grant motion to 


\section{Discovery Courts and Their Rulings}

While cases are in the jurisdiction of a section 1407 transferee court, issues raised therein may be brought for resolution to other district courts in which discovery is proceeding. ${ }^{337}$ The discovery court may be asked to rule upon a matter in which a transferor court, the section 1407 court, or another discovery court already has ruled, or it may be asked to rule upon an issue arising in the litigation for the first time. The issue may then resurface in the section 1407 court or in other courts that become involved in the multidistrict litigation. How have the courts playing these various positions handled such prior rulings?

In re Multi-Piece Rim Products Liability Litigation ${ }^{\mathbf{3 3 8}}$ involved a group of products liability cases in which the safety of multipiece wheels and wheel rims was at issue. ${ }^{389}$ Prior to section 1407 consolidation, Firestone Tire \& Rubber Company, a defendant, had obtained from the clerk of the District Court for the District of Columbia a subpoena for the production of documents by the Insurance Institute for Highway Safety ("IIHS") in a case ${ }^{\mathbf{3 4 0}}$ pending in Alabama federal court. $^{\text {s41 }}$ IIHS, in turn, had obtained from the District of Columbia court a protective order against inquiries relating to the preparation, accuracy, or reliability of IIHS petitions which had asked the National Highway Traffic Safety Administration ("NHTSA") to investigate defects in multi-piece wheels. ${ }^{842}$ After the case became part of section 1407 litigation consolidated in the Western District of Missouri, the section 1407 judge designated as a common issue for multidistrict discovery "whether any reports prepared by, any governmental body pertaining to multi-piece rims and/or . . . wheels are accurate and trustworthy."

dismiss complaint, where he was clearly convinced of error in state judge's prior contrary ruling); Barrett v. Baylor, 457 F.2d 119, 124 (7th Cir. 1972) (rulings of state courts are binding on federal courts under law of the case); see 1B MOORE's FeDERAL Practice, supra note 7 I $0.404[7]$, at 155-56. The law of the case consequences of such state law rulings are not peculiar to federal multidistrict litigation, however. It would appear that the analysis proposed herein concerning the handling of federal transferor court rulings would apply as well to the rulings of state courts from which cases were removed.

${ }^{287}$ See, e.g., FED. R. Crv. P. 30(d) (enabling "the court in which the action is pending or the court in the district where the deposition is being taken" to terminate the deposition or to limit its scope and the manner of its taking) (emphasis added).

22853 F.2d 671 (D.C. Cir. 1981).

230 Id. at 673-74.

240 Clayton v. Firestone Tire \& Rubber Co., Civ. No. 78-G0396S (N.D. Ala. May 3, 1984).

Multi-Piece Rim, 653 F.2d at 674.

24 Id. at 674-75.

413 Id. at 675 . The record indicated that the $\S 1407$ judge was not informed of the 
Firestone then tried again to obtain from IIHS information about the preparation and accuracy of its petitions to NHTSA. When IIHS refused to comply, Firestone asked the section 1407 judge to enter an order compelling discovery. The judge ruled that only the District of Columbia court had jurisdiction to direct compliance with its own subpoenas. ${ }^{344}$ Firestone then commenced a civil action in the District of Columbia court to compel discovery. The judge had to determine, inter alia, what weight to give to the protective order entered by his District of Columbia colleague prior to section 1407 consolidation and what weight and meaning to attribute to the section 1407 judge's designation of common issues for multidistrict discovery. He denied Firestone's motion to compel, holding that the protective order was sound and should govern as law of the case and that the multidistrict judge's designation did not cover the IIHS's petitions, which were not government reports. ${ }^{845}$

On appeal, the Court of Appeals for the District of Columbia ${ }^{348}$ held that the section 1407 court's designation of issues subject to discovery in the multidistrict proceedings was meant only to distinguish between issues appropriate for consolidated discovery and local issues to be handled contemporaneously by the various transferor courts; it was not a ruling on the propriety of protective orders in the designated subject areas. ${ }^{347}$

The court expressed the view that law of the case doctrine has application in multidistrict litigation, but immediately cautioned that the "sound exercise of the discretion implicit in this doctrine requires

protective order entered by the District of Columbia court. Id.

s4 Id. at 675. The Court of Appeals for the District of Columbia refused to express an opinion as to whether this jurisdictional ruling was in error. Id. at 675-76 n.1. It arguably was in error because $\S 1407$ (b) empowers the transferee judge to "exercise the powers of a district judge in any district for the purpose of conducting pretrial depositions." See In re Gorrugated Container Antitrust Litig., 662 F.2d 875, 880-81 (D.C. Cir. 1981) [hereinafter Corrugated Container V] ( $\$ 1407$ transferee judge had power to adjudge appellant in contempt and to set a penalty while acting as a judge of the District of Columbia district court; any appeal from the exercise of his powers belonged in the Court of Appeals for the District of Columbia). The decision in In re Wheat Farmers Antitrust Class Action, 440 F. Supp. 1022, 1024 (D.D.C. 1977), is not to the contrary. The court there held that a discovery court properly could rule on a plaintiff's motion under Rules 37(a) and 45(d) of the Federal Rules of Civil Procedure for production of documents directed at nonparty deponents whose depositions were taken, and to whom subpoena duces tecum issued, in the judicial district, although the case was part of $\S 1407$ proceedings consolidated elsewhere. Wheat Farmers did not hold that the $\S 1407$ judge lacked authority to rule on plaintiff's motion.

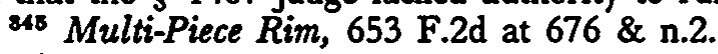

248 Because the litigation was in the District of Columbia district court solely on discovery motions, its disposition was an appealable final judgment. Id. at 676. The appeal was properly to the District of Columbia Circuit under 28 U.S.C. § 1294.

347 Multi-Piece Rim, 653 F.2d at 676-77 \& 677 nn.3-4. 
attention to the special authority granted to the multidistrict transferee judge." 48 Transferee judges' orders can supersede other courts' orders, and even when they do not, they may require reexamination of the rationale of those other orders so that properly coordinated handling will be afforded. ${ }^{340}$ Thus, the court opined that total reliance on law of the case doctrine would have been an abuse of discretion and an "evasion of a district court's responsibilities." 350 The intervening orders of the section 1407 judge required reexamination of the propriety of a previously issued protective order, for it could no longer govern if inconsistent with the section 1407 court's definition of the proper scope of discovery in the consolidated cases. ${ }^{351}$ The court held, however, that the district judge had reexamined the propriety of the protective order, had correctly found it not to conflict with the section 1407 judge's discovery program, and had found it to be sound, on the basis of an analysis which was proper under an abuse of discretion standard of review. ${ }^{362}$ Finally, the Court of Appeals for the District of Columbia paid further deference to the section 1407 court, saying that this decision in no way restricted the power of the multidistrict judge to define, clarify, or expand the scope of his pretrial order if he concluded that further discovery was appropriate. ${ }^{.68}$

In the Multi-Piece Rim Products litigation, the vitality of the challenged protective order apparently was raised solely in the case that generated it. ${ }^{854}$ In that context, the court was correct to disparage Firestone's contention that law of the case has no application to a ruling in an individual case once that case has been consolidated into a multidistrict proceeding. ${ }^{865}$ If the subpoenas that Firestone most recently had obtained and the orders it sought from the District of Columbia court

s. Id. at 678 .

240 Id.

${ }^{350} I d$.

${ }^{252}$ Id; cf. In re Wheat Farmers Antitrust Class Action, 440 F. Supp. 1022, 1025 (D.D.C. 1977) (discovery court would determine motion for production of documents under the broad standard of relevance set forth in Rule 26 of the Federal Rules of Civil Procedure as limited by the scope of a particular "wave" of discovery defined by the $\S 1407$ court).

282 Multi-Piece Rim, 653 F.2d at 679-80. The court also held that the district court did not abuse its discretion in refusing to award to IIHS the expenses it incurred in opposing Firestone's motion. Id. at 680-81.

${ }_{283}$ Id. at 680. See also ABC Great States, Inc. v. Globe Ticket Co., 316 F. Supp. 449, 450-51 (E.D. Pa. 1970) (in civil antitrust actions against manufacturers of admission tickets, consolidated under $\S 1407$, discovery court held to be law of the case its prior ruling, by a different judge, that subpoena requiring production of certain Justice Department sentencing memoranda must be quashed).

sst Multi-Piece Rim, 653 F.2d at 678 n.5.

2ss Firestone argued that "all prior orders spontaneously lose their validity at the moment of consolidation." Id. 
had applied to the entire multidistrict litigation, however, the District of Columbia court would have had before it not only a law of the case problem, but also the question of whether to expand its protective order to the other consolidated cases.

In evaluating the Multi-Piece Rim case, it is also noteworthy that the District of Columbia courts did not perceive any choice of law question as to whose law of the case doctrine applied. Like other courts, they applied their own understanding without remark or defense. Use of the law of the District of Columbia does appear to be correct, however, as it was the District of Columbia court which entered the original protective order and there is no indication that the District of Columbia court, acting as a discovery court in entering that protective order, either purported to apply, or should have applied, the law on protective orders that would have been applied by the Northern District of Alabama, the court where the action was then pending and that became the transferor court.

The Multi-Piece Rim court's treatment of the law of the case issue with respect to the doctrine's content was also pragmatic and intelligent. The court clearly appreciated the need to modify standard doctrine to reflect the policies and purposes of multidistrict pretrial consolidation. In requiring sensitive cooperation with the multidistrict transferee court and deference to its command, the court expressed a constructive philosophy essential to the smooth operation of section 1407's multidistrict system. Had it so desired, the District of Columbia court also could have found justification for examining the subject protective order in the notion that such orders are inherently open to modification in light of changed circumstances.

Consistent with its positive attitude, the court did not discuss the possibility that other discovery courts might render its protective order futile by failing to immunize from discovery the same subject areas and materials as the District of Columbia court had immunized. It may be, however, that the IIHS and its representatives were not subject to discovery proceedings in any court other than that of the District of Columbia. Moreover, if another discovery court were faced with the same issue in the same case, it might well follow the District of Columbia's ruling as law of the case. In any of the other consolidated actions, the District of Columbia ruling would be merely persuasive. In any event, as simply a discovery court in this litigation, the District of Columbia Court had no control over what other participant courts might do.

In Multi-Piece Rim, a discovery court was asked to defer under law of the case to a section 1407 court ruling. In other situations, a discovery court might be asked to defer to prior rulings by one or more 
transferor courts. In these situations, the discovery court should apply the law of the case doctrines that those ruling courts would have applied, including whatever they may have held concerning the operation of the doctrine in multidistrict litigation, unless the burden of so doing or the resulting conflicts dictate that it use a single doctrine, such as its own. Ideally, in content the doctrine should take into account the likelihood (or unlikelihood, as the case may be) of the actions returning to their transferor courts for trial. The greater the possibility, the stronger the argument for deference, absent a significant change in the facts or controlling law. The doctrine also should take into account the magnitude of the need for horizontal consistency among the consolidated cases on the particular issue in question. Depending on the circumstances, these two concerns may either point to the same outcome or to different outcomes, so that one will have to outweigh the other.

Ultimately, the discovery court has to decide whether to adhere to prior rulings and, if change is necessary, how to modify them. One point meriting attention is that a discovery court's orders are appealable to its own court of appeals, which will apply its own interpretations of the discovery rules and doctrines. ${ }^{358}$ This is true whether the discovery court judge normally sits there or is functioning as the section 1407 judge exercising her powers under section 1407(b) to employ the powers of a judge of another district to preside over depositions. ${ }^{35 z}$ If the law of the case argument urged upon a discovery court is predicated

sse See, e.g., In re Burlington N., Inc., 679 F.2d 762 (8th Cir. 1982). At least one court of appeals for a $\S 1407$ transferee district court has held that it lacks jurisdiction to hear appeals by non-party witnesses deposed elsewhere. See In re Corrugated Container Antitrust Litig., 647 F.2d 460, 461 (5th Cir. 1981) [hereinafter Corrugated Container III], cert. denied, 449 U.S. 1102 (1981), citing In re Corrugated Container Antitrust Litig., 620 F.2d 1086, 1090-91 (5th Cir. 1980) [hereinafter Corrugated Container I], cert. denied, 449 U.S. 1102 (1981). The Second Circuit later commented that it expressed "no opinion as to the correctness of the Fifth Circuit's determination concerning its own jurisdiction." In re Corrugated Container Antitrust Litig., 644 F.2d 70, 74 n.6 (2d Cir. 1981) [hereinafter Corrugated Container II].

${ }^{357}$ In re Corrugated Container Antitrust Litigation, 662 F.2d 875, 877, 879-81 (D.C. Cir. 1981) [hereinafter Corrugated Container V] (District of Columbia Circuit had jurisdiction over appeal from $\S 1407$ transferee judge's order of contempt issued over the telephone from his home district to a non-party witness being deposed in Washington, D.G.); In re Corrugated Container Antitrust Litig., 655 F.2d 748, 750 n.2 (7th Cir. 1981), rev'd on other grounds, 661 F.2d 1145 (1981) (en banc), aff'd sub nom. Pillsbury Co. v. Colby, 459 U.S. 248 (1983) (Seventh Circuit had jurisdiction over appeal from $\S 1407$ transferee judge's order of contempt to a nonparty witness being deposed in the Northern District of Illinois); Corrugated Container II, 644 F.2d at 73-74 \& n.6 (Second Circuit had jurisdiction over appeal from $\S 1407$ transferee judge's order of contempt to a non-party witness being deposed in the Southern District of New York). The Fifth Circuit, as the court of appeals for the $\S 1407$ transferee court, had dismissed appeals to it for lack of jurisdiction. See Corrugated Container III, 647 F.2d at 460, and Corrugated Container I, 620 F.2d at 1090-91. 
upon a ruling of a court in another circuit which would be erroneous in the discovery court's circuit, ${ }^{358}$ the discovery court will have to depart from the law of the case in order to avoid reversal. ${ }^{350}$ The possibility is thus created that discovery courts around the country, as well as the section 1407 transferee court, will be obliged to take conflicting positions on discovery issues in the section 1407 consolidated proceedings. ${ }^{380}$ This would be a patent contradiction of the remedial aim of section 1407: to eliminate the potential for conflicting contemporaneous pretrial rulings by coordinate district and appellate courts in multidistrict litigation. The appellate discovery courts have appreciated the problems, but have found bases in policy, in section 1407, in section $1294,{ }^{361}$ and in the Federal Rules of Civil Procedure, for upholding their jurisdiction. ${ }^{362}$ They seem to have either not considered, or silently rejected, the idea of applying the discovery precedents of the designated transferee forum.

There may be no solution to this problem when discovery is sought from non-party witnesses over whom a section 1407 transferee court cannot exercise jurisdiction. ${ }^{863}$ Even if federal discovery courts and their appellate counterparts were willing to depart from the competence principle to apply the discovery law of the section 1407 transferee court, it is questionable whether it would be appropriate to apply to a nonparty deponent the discovery law of a court which could not

${ }^{358}$ Conflicts among the circuits on issues related to discovery are not uncommon. See, e.g., Seattle Times Co. v. Rhinehart, 467 U.S. 20, 28-29 (1984) (addressing an intercircuit conflict relating to the trial court's authority to restrict dissemination of information produced during discovery).

8s9 Multi-Piece Rim, 653 F.2d at 678 n.5 (D.C. Cir. 1985).

380 Appellate proceedings for early review of pretrial rulings by the transferee court lie in the court of appeals for the transferee district from the time of transfer until remand. Utah v. American Pipe \& Constr. Co., 316 F. Supp. 837, 839 (G.D. Cal. 1970).

88128 U.S.C. § 1294 (1982).

862 The Second Circuit recognized the argument that the purposes of $\S 1407$ "would be best served by permitting appeals to only one circuit," that of the transferee court, but concluded that it had jurisdiction in light, inter alia, of its own interest in overseeing and ensuring uniformity of treatment in discovery conducted by its district judges or judges exercising the powers of its district judges and the inconvenience of forcing non-party witnesses to appeal to distant circuit courts. Corrugated Container II, 644 F.2d at 74 n.6. The District of Columbia Circuit likewise noted the "potential lack of uniformity engendered by appellate review by different circuit courts", but found a trade-off in the "need for uniformity in decisions on depositions within each of those circuits." Corrugated Container V, 662 F.2d at 881 n.11.

${ }^{3 e s}$ In Corrugated Container II, 644 F.2d at 74 n.6, the Second Circuit noted that if not for the provision of $\S 1407$ (b) that allowed the Chief Judge of the Southern District of Texas to exercise the powers of a judge from the Southern District of New York, a district judge from that district would have had to preside over the deposition of a non-party witness who resided in New Jersey and was deposed in New York. 
assert personal jurisdiction over her. ${ }^{364}$ By contrast, party deponents can be required to appear for deposition in the section 1407 transferee court district in order to assure that consistent discovery rulings will be made. ${ }^{365}$ Accordingly, it will be possible to keep discovery courts off the horns of a dilemma when discovery from parties is at issue.

As to the reverse question of the effect of discovery court rulings upon other participating courts, In re Burlington Northern, Inc. ${ }^{\mathbf{3 6 8}}$ is instructive. Burlington Northern and several unions were sued in employment discrimination cases that the Panel transferred to the Northern District of Illinois. ${ }^{387}$ A Burlington employee was deposed in Minnesota, where, under instructions of counsel, he refused to answer several questions on the grounds of privilege. ${ }^{388}$ The consolidated plaintiffs moved to compel. ${ }^{369}$ Earlier, in the section 1407 transferee court, the plaintiffs had filed a motion to compel production of certain documents that had been withheld on the basis of the same privilege, but that motion was still pending. ${ }^{370}$ Judge Lord, the Minnesota trial judge, held that the testimony was not privileged and granted plaintiffs' motion to compel. ${ }^{371}$

After Judge Lord's ruling, Burlington sought a writ of mandamus directing Judge Lord to vacate his order. Among other points, it argued that Judge Lord abused his discretion in ruling at all on the motion to compel. In light of the policy objectives of multidistrict litigation, Burlington argued, Judge Lord should have remitted the plaintiffs to the transferee court as the more appropriate forum. ${ }^{372}$ If the deponent was a managing agent of Burlington, this remission could have been accomplished under Rule 37(a)(1)..$^{378}$ If the deponent was not such a manag-

so4 Compare the impropriety of a $\S 1404$ or $\S 1406$ transferee court applying the law of a tranferor court that had no personal jurisdiction over the defendants. See supra note 192 and accompanying text.

ses See FED. R. Crv. P. 26(c). On the theory that plaintiff selected the place for trial, plaintiffs often are held obligated to present themselves at that place for their depositions. 4 MOORE's FeDERAL PRACTICE, supra note 7, II 26.70 [1.-2], at 26-449. That rationale loses its force when a case has been transferred at the urging of someone other than the plaintiff. Nonetheless, the place where discovery may be had of plaintiffs and of defendants is a matter in the court's discretion, unrestricted by the necessity of compelling attendance through a subpoena. Id. at II 26.70 [1.-2 \& 1.-3].

${ }^{380} 679$ F.2d 762 (8th Cir. 1982).

387 Id. at 763.

s68 Id. Privilege was claimed on the grounds that the information sought would have disclosed Burlington's "self critical subjective analysis of its employment practices." Id.

ses Id. at 764 .

370 Id. at 763-64.

871 Id. at 764 .

${ }^{372}$ Id. at $765-66$.

873 Under Rule 37(a)(1), FED. R. Crv. P., "An application for an order to a party 
ing agent, ${ }^{374}$ Burlington argued, Judge Lord either should have declined to rule until the section 1407 court had ruled on the asserted privilege, transferred the motion to compel to the section 1407 court, or directed plaintiffs to seek to have the motion heard by the section 1407 judge sitting as a specially designated district judge of the District of Minnesota pursuant to section 1407 (b). ${ }^{378}$ The Eighth Circuit ruled that, although the arguments with respect to the handling of non-party depositions in multidistrict litigation were "not without some merit," the case did not present an extraordinary situation warranting mandamus. ${ }^{377}$ None of the reasons it marshalled responded further to Burlington's abuse of discretion arguments.

Each of the alternative courses of action that Burlington argued Judge Lord should have taken is available to a discovery court. ${ }^{378}$ Of course, the choice of any of these alternatives will not create any law of the case to be contended with thereafter. In enacting section 1407, however, Congress certainly did not intend to deprive section 1407 transferee courts of the assistance of courts around the country within whose jurisdiction discovery of non-parties is proceeding, nor would such a course of action be desirable. Section 1407 transferee judges and other designees of the Panel are authorized and permitted to exercise the

may be made to the court in which the action is pending. . .." (emphasis added).

874 His status apparently was in issue. See Burlington Northern, 679 F.2d at 765-66.

${ }^{378}$ Burlington Northern, 679 F.2d at 765-66. Under Rule 37(a)(1) of the Federal Rules of Civil Procedure, "An application for an order to a deponent who is not a party shall be made to the court in the district where the deposition is being taken."

${ }^{376}$ Burlington Northern, 679 F.2d at 767.

327 Id.

378 See In re Uranium Antitrust Litig., 503 F.Supp. 33, 34 (N.D. Ill. 1980) (motions relating to non-party discovery are transferable to $\S 1407$ court); Socialist Workers Party v. United States Attorney General, 73 F.R.D. 699, 700-01 (D. Md. 1977) (where issues were complex and required balancing of alleged privileges and important constitutional rights, discovery court transferred non-parties' request for protective orders to court in which action was pending); Bank of Texas v. Computer Statistics, Inc., 60 F.R.D. 43, 45 (S.D. Tex. 1973) (Rule 26(c) did not preclude discovery court from transferring request for protective order to court in which action was pending); 4 MOORE's Federal PRACTICE, supra note 7, II 26.01[21], at 26-45.

Some $\S 1407$ courts have exercised their power under $\S 1407(\mathrm{~b})$ to preside at depositions outside their home districts by acting as a judge of the district court where depositions of non-party deponents were being taken. See In re Corrugated Containers Antitrust Litig. 655 F.2d 748, 750 (7th Cir.) [hereinafter Corrugated Containers IV] (trial judge invoked his authority to exercise the powers of a judge in the Northern District of Illinois), rev'd on other grounds, 661 F.2d 1145 (1981) (en banc), affd, 459 U.S. 248 1983); In re Uranium Antitrust Litig., 503 F. Supp. at 35 (transferee court stated that it would go to other districts to hear and decide motions to compel discovery from non-parties); In re IBM Peripheral EDP Devices Antitrust Litig., 411 F. Supp. 791, 792 (J.P.M.D.L. 1976) (transferee judge is empowered to preside at depositions in any federal district). 
powers of a district judge in any district for the purpose of conducting pretrial depositions in multidistrict proceedings; they are not required to undertake those responsibilities. ${ }^{379}$ The Eighth Circuit's opinion does not make clear whether Burlington believed that discovery court judges always should defer to the section 1407 court as the more appropriate forum or, as is more likely, whether Burlington argued that the discovery court, in the sound exercise of discretion, should have declined to rule because of the special circumstances of the case. The opinion also leaves unclear just why Burlington thought this case was special or why this issue was one on which only the transferee judge should rule. Perhaps it expected the privilege issue, an important matter to Burlington, to arise in several discovery courts and thus sought to avoid inconsistent decisions. ${ }^{\mathbf{3 8 0}}$ Perhaps it merely believed the section 1407 judge would be more favorably disposed toward its contentions than was Judge Lord. In any event, its arguments did not prevail, at least on a petition for writ of mandamus.

Because discovery courts do rule in multidistrict cases, the questions arise as to what law of the case consequences their rulings are, and should be, given. ${ }^{881}$ One preliminary point should be made in answering this question. It was argued earlier that in determining whether any court's rulings should be accorded respect, a court should consider whether the court whose ruling is challenged had subject matter jurisdiction over the case, personal jurisdictional over the parties, and was a proper venue. ${ }^{382}$ In the case of rulings by a discovery court, the discovery court would need only to have been a proper federal court

s70 Section 1407(b) says that particular judges "may" exercise such powers, not that they must. 28 U.S.C. $\S 1407$ (b) (1982). A number of $\S 1407$ judges have elected not to exercise their $\S 1407$ (b) powers on various occasions. See, e.g., In re Multi-Piece Rim Prods. Liab. Litig., 653 F.2d 671 (D.C. Cir. 1981), and supra text accompanying notes 335-352); In re Wheat Farmers Antitrust Class Action, 440 F. Supp. 1022 (D.D.C. 1977).

380 Transcript of Proceedings on January 13, 1982, at 23, 27, In re Burlington $N$. R.R, No. 78 G 269, MDL 374 [hereinafter Transcript] (copy on file with the University of Pennsylvania Law Review), before the $\S 1407$ transferee judge, shows that counsel for Burlington Northern explained that its objection to having Judge Lord rule was grounded in the need for a uniform decision that would guide it throughout the case.

s81 The existence of problems deriving from the use of discovery courts apart from the district court in which an action is pending is by no means limited to situations of $\S 1407$ transfers. See, e.g., McCandless v. Beech Aircraft Corp., 697 F.2d 1156, 115960 (D.C. Cir. 1983) (pending a ruling by primary district judge, discovery court declines to rule on motion to quash subpoena for deposition and documents because of danger that discovery court and the primary district judge might disagree, resulting in either gross prejudice if discovery were disallowed or intrusion if it were permitted, and because certain parties had not been heard on the issue and were not parties to the appeal and this made particularly unclear whether any ruling by the discovery court would be binding on the primary district judge).

ss2 See supra text accompanying notes 192-200. 
to determine the issues presented to it, under the federal discovery rules and Rule 45, concerning subpoenas. ${ }^{383}$

Assuming that, as far as these requirements are concerned, respect may be due a prior decision, the initial question will be whether law of the case really is at issue. If both the issue and the particular case are the same, a law of the case argument will be available to the party favored by the earlier ruling. If the prior ruling was made in a different component case of the multidistrict consolidation, law of the case doctrine should not be applied, even if the prior ruling is particularly persuasive because of the desirability of uniformity in the consolidated cases. $^{384}$

The next concern is whose law of the case doctrine should apply. A single discovery court repeatedly faced with a particular issue in a given multidistrict litigation can be expected to apply its own law of the case doctrine and to adhere to a prior ruling, absent contra-indications from the section 1407 court or from other courts, or the applicability of some other exception to its law of the case doctrine. ${ }^{385} \mathrm{~A}$ remand court, the section 1407 transferee court, or a discovery court faced with the argument that law of the case principles require deference to the ruling of another discovery court should apply the law of the case doctrine that would be used by the court that previously ruled. This application should include whatever that court may have held concerning the operation of the doctrine in multidistrict litigation. If multiple rulings are in question, however, the burden of applying the previous courts' doctrines or the conflicts that would result may justify use of a single doctrine, such as that of the court where reconsideration is sought.

Ideally, the content of the doctrine should take into account the probability of remand or further transfer, as well as the magnitude of the need for horizontal consistency among the presently or recently consolidated cases. When a discovery court ruling is challenged in the section 1407 transferee court, special considerations apply. Generally, the section 1407 transferee court should let a previous court's ruling stand unless a law of the case exception is applicable. In light of the special responsibility of the section 1407 transferee court to control discovery in the consolidated cases and to prevent the pretrial chaos that can exist as a result of conflicting rulings, however, an exception to law of the case

s8s FED. R. Giv. P. 30(d), 45(d).

so4 See supra text accompanying note 89.

${ }^{385}$ See, e.g., ABC Great Stores, Inc. v. Globe Ticket Co., 316 F. Supp. 449 (E.D. Pa. 1970). But see In re Subpoena to Ford Aerospace \& Communications Corp., 27 Fed. R. Serv. 2d (Callaghan) 402, 404 (E.D. Pa. 1979) (deposition court ruling on non-party deponent's assertion of privilege declares its ruling "without prejudice" in light of greater expertise of court before whom underlying litigation is pending). 
doctrine should be recognized ${ }^{386}$ so that the transferee court can arrive at its own conclusion, and in so doing guide the other courts performing auxiliary roles. If the parties' law of the case argument relates to a ruling that would be erroneous in the court where reconsideration is sought, a departure from the ruling will be necessary to avoid reversal. Again, this will create the possibility that the various participating courts will be obliged to take conflicting stances on discovery issues, in contradiction of the remedial aims of section 1407. There is currently no mechanism, however, that can eliminate this problem.

In the Burlington Northern case, ${ }^{387}$ the section 1407 transferee judge declined to rule on the privilege issue decided by Judge Lord until the Eighth Circuit had acted on Burlington's petition for writ of mandamus. The transferee court indicated that it would be inclined to follow the Eighth Circuit's decision. ${ }^{\mathbf{8 8 8}}$ It nowhere indicated, however, that it thought that the privilege matter raised law of the case issues. When the court later ruled on Burlington's claim to a self-critical analysis privilege, it rejected the privilege without any reference to Judge Lord's earlier ruling to the same effect. ${ }^{388}$ It focused entirely on the merits of the asserted privilege and not at all on whether any of the courts to which these cases might be remanded or further transferred recognized such a privilege or on whether the ruling should be influenced by those facts. According to the analysis presented herein, the Eighth Circuit was free to rule as it saw fit. Perhaps because it had decided to rule consistently with Judge Lord's opinion, the court thought it superfluous to make any mention of law of the case doctrine.

\section{Transferee Court Rulings}

Section 1407 transferee courts may, of course, be asked to reconsider their own prior rulings. In such circumstances, a change of judge may or may not be involved, as there may have been a predecessor section 1407 judge. Although there will not have been a transfer intervening between the initial ruling and the request for reconsideration, there may have been intervening decisions by discovery courts, interlocutory appeals to the court of appeals for the section 1407 court, or other changes in circumstances. Additionally, "tag along" actions that

s86 Cf. In re Upjohn Co. Antibiotic Cleocin Prods. Liab. Litig., 664 F.2d 114 (6th

Cir. 1981) [hereinafter Upjohn II] and supra text accompanying notes 316-36.

s87 See supra notes 366-80 and accompanying text.

sss See Transcript, supra note 380, at 24, $27-28$.

s89 EEOC v. Burlington N., Inc., No. 78 C 269 MDL 374 (Dec. 16, 1982) (memorandum opinion) (copy on file with the University of Pennsylvania Law Review). 
were independent or not yet filed at the time of the initial ruling by the section 1407 judge may have been made part of the multidistrict litigation. ${ }^{380}$ If a tag along party requests reconsideration, law of the case is inapplicable. Otherwise, the law of the case doctrine of the section 1407 court, with its standard exceptions, will apply. A change in the law, the facts presented, or the parties represented ordinarily should evoke reconsideration.

Once again it is worth noting a few basics. The section 1407 court will have subject matter jurisdiction over the transferred cases, if any federal district courts do. ${ }^{301}$ Section 1407 itself renders the transferee court a proper venue for purposes of coordinated or consolidated pretrial. ${ }^{322}$ Finally, the section 1407 court is unlikely to be one that cannot constitutionally assert jurisdiction over the parties. As long as defendants have minimum contacts with the United States such that maintenance of the suit in a federal court does not offend traditional notions of fair play and substantial justice, the section 1407 court's assertion of jurisdiction will be constitutional. ${ }^{393}$ Arguably, section 1407 courts are statutorily authorized to assert personal jurisdiction over the parties to the multidistrict litigation. ${ }^{384}$ If not, then either it is unnecessary for the

s80 A "tag-along" case is a civil action involving common questions of fact with actions previously transferred under $\S 1407$. FED. R.P. OF THE J.P.M.D.L. 1 (1982).

${ }^{801}$ There could be an exception to this statement under the "forum doctrine." See FRIEDENTHAL, supra note $8, \S 2.6$, at 36 . However, research has not uncovered any instance in which jurisdiction of a $\S 1407$ transferee court was challenged on this ground.

392 The statutory requirement of 28 U.S.C. $\S \S 1404$ and 1406 , that transfer be made only to a district or division where a case could or might have been brought, is simply inapplicable. In re Vernitron Sec. Litig., 462 F. Supp. 391, 394 (J.P.M.D.L. 1978) ("The Panel's discretion under section 1407 is not limited by venue considerations."); In re FMC Corp. Patent Litig., 422 F. Supp. 1163, 1165 (J.P.M.D.L. 1976). With respect to the factors influencing the choice of transferee forum, see 15 WRIGHT \& MILLER, supra note $7, \S 3864$.

${ }_{393}$ See Federal Trade Comm'n v. Jim Walter Corp., 651 F.2d 251, 256 (5th Cir. 1981) ("due process requires only that a defendant in a federal suit have minimum contacts with the United States"); Fitzsimmons v. Barton, 589 F.2d 330, 333 (7th Cir. 1979) (defendant, a resident citizen of the United States, had sufficient contact with the United States to support the exercise of jurisdiction over him by a federal district court for a district in which he did not reside); In re Sugar Indus. Antitrust Litig., $399 \mathrm{~F}$. Supp. 1397, 1400 (J.P.M.D.L. 1975) (rejecting, as without merit, defendants' contention that a $\S 1407$ transfer order would deprive them of due process because they do not have minimum contacts with California, site of the $\$ 1407$ transferee court); but cf. Oxford First Corp. v. PNC Liquidating Corp., 372 F. Supp. 191, 203-04 (E.D. Pa. 1974) (testing the validity of a nationwide service of process statute, not by the due process strictures defined in International Shoe, but by a fairness test relying, in part, on the extent of defendant's contacts with the place (the judicial district) where the action was brought and the inconvenience to defendant of having to defend there).

304 Rule 4 of the Federal Rules of Civil Procedure states in part:

(e) . . . Whenever a statute of the United States or an order of court thereunder provides for service of a summons, or of a notice, or of an 
section 1407 court to have in personam jurisdiction over the parties, or its personal jurisdiction derives from the transferor court or a potential transferee court that can assert such jurisdiction. ${ }^{395}$ In short, a section 1407 court will not have grounds to refuse to respect its own rulings on the grounds that it lacked subject matter jurisdiction over the case, was not a proper venue, or lacked personal jurisdiction over the parties.

An example of a section 1407 transferee court reconsidering its own ruling is Philadelphia Housing Authority v. American Radiator E Standard Sanitary Corp. ${ }^{306}$ In that litigation, Chief Judge John Lord, presiding as the multidistrict judge, had granted defendants' motions to dismiss the antitrust complaints of certain home and building owners allegedly damaged by illegal price-fixing of plumbing fixtures. $^{897}$ After reassignment of the litigation to Judge Harvey, also of the Eastern District of Pennsylvania, defendants moved for summary judgment on certain similar claims of public agencies that had purchased plumbing fixtures for incorporation into public structures. ${ }^{398}$ Judge Harvey held that Mangano v. American Radiator $\mathcal{O}$ Standard Sanitary Corp. ${ }^{398}$ (the leading decision by Judge Lord) would be adhered to as law of the case. ${ }^{400} \mathrm{He}$ found that the change of judge presented no reason to depart from law of the case principles. ${ }^{401} \mathrm{He}$ evaluated Judge Lord's opinion as having comprehensively and carefully discussed the principles which controlled the issues presented and noted that no subsequent decisions suggested a different result. On the

order in lieu of summons upon a party not an inhabitant of or found within the state in which the district court is held, service may be made under the circumstances and in the manner prescribed by the statute or order, or, if there is no provision therein prescribing the manner of service, in a manner stated in this rule.

(f) Territorial Limits of Effective Service. All process other than a subpoena may be served anywhere within the territorial limits of the state in which the district court is held, and, when authorized by a statute of the United States or by these rules, beyond the territorial limits of that state.

FED. R. Grv. P. 4(e), (f). Section 1407 arguably is a statute providing for service of a notice on parties outside the $\S 1407$ court's state, sufficient to bring the parties within the $\$ 1407$ court's jurisdiction for purposes of coordinated or consolidated pretrial.

${ }^{\text {s9s }}$ In re Highway Accident Near Rockville, 388 F. Supp. 574, 576 (J.P.M.D.L. 1975) ("the propriety of in personam jurisdiction in a proposed transferee district is not a criterion in considering transfer . . u under Section 1407"); In re Truck Accident Near Alamagordo, 387 F. Supp. 732, 734 (J.P.M.D.L. 1975) (same). By similar reasoning, discovery courts do not need to be able to assert personal jurisdiction over the parties.

39323 F. Supp. 381 (E.D. Pa. 1970).

397 Id. at 382 \& n.3.

398 Id. at $382,382-83$ n.4.

39950 F.R.D. 13 (E.D. Pa. 1970), affd, 438 F.2d 1187 (3d Cir. 1971).

${ }^{100}$ Philadelphia Hous. Auth., 323 F. Supp. at 383-84.

101 Id. at 383. 
contrary, all intervening decisions were either consistent with Mangano or factually distinguishable from the cases before the Pennsylvania federal court. ${ }^{402}$ In addition, Mangano was then on appeal, so no worthwhile purpose would be served by the district court reexamining the authorities and arguments on the issue. ${ }^{403}$ Finally, Judge Harvey commented that law of the case doctrine "is particularly applicable to multidistrict litigation in which the presence of a large number of diverse parties might otherwise result in constant relitigation of the same legal issues." 404

Judge Harvey's decision not to reexamine the legal issue presented is sensible, but his decision should not have rested on law of the case for two reasons. First, the particular civil actions presenting the question whether public bodies could assert the antitrust claims being made were not part of the multidistrict litigation at the time Judge Lord made his prior rulings. Although Judge Lord's rulings were law of the case for those civil actions before him and directly affected by his rulings, his rulings were not law of the case in actions only later consolidated into the section 1407 proceedings. Imposing his ruling upon new litigants without affording them an opportunity to be heard raises substantial due process questions. Second, because the section 1407 court had not previously ruled on the antitrust claims of public, as opposed to private, agencies, there was arguably no law of any of the multidistrict cases on the question. If the prior rulings had been made in the same case, the only issues to be briefed might have been whether, how, and why public bodies should be differently treated than private entities. But because the prior rulings had been entered in different cases and before the multidistrict net had been cast over the cases facing Judge Harvey, a broader right to be heard was involved. ${ }^{405}$

Despite these two objections to Judge Harvey's application of law of the case principles, it would have been wasteful for him to have reconsidered the authorities and arguments on the set of issues raised by defendants' motion to dismiss. Mangano was on appeal and, there-

402 Id. at 383-84. Decisions pre-dating Mangano and inconsistent with it also pre-dated a landmark United States Supreme Court case, Hanover Shoe, Inc. v. United Shoe Mach. Corp., 392 U.S. 481 (1968), upon which Mangano relied heavily, and hence were of little precedential or persuasive value. Id. at 383-84.

${ }^{403}$ Id. at 383. Judge Lord's decision in Mangano was affirmed on appeal, 438 F.2d 1187 (3d Cir. 1971). The United States Supreme Court ultimately agreed that such plaintiffs had no standing to sue. See Illinois Brick Co. v. Illinois, 431 U.S. 720 (1977).

${ }^{04}$ Philadelphia Hous. Auth., 323 F.Supp. at 383. After further discussion not pertinent here, Judge Harvey granted defendants' motions and dismissed the affected claims. Id. at 384-87.

${ }^{108}$ See supra text accompanying notes 84-86. 
fore, an opinion that would control Judge Harvey's decision was in the offing. He properly could have either refrained from deciding until the Third Circuit spoke or followed the Mangano decision as stare decisis, without giving microscopic scrutiny to the issues. The latter approach is available in multidistrict litigation even when issues are not on appeal.

Certainly Judge Harvey correctly concluded that constant relitigation of essentially the same legal issues, at the successive behests of a multitude of litigants, should not be permitted in section 1407 transferee courts. To allow such relitigation would undermine the purposes of expediting litigation through coordinated pretrial under a single judge. Still, a court should ignore neither the operative scope of law of the case doctrine nor the parties' due process rights; consolidated pretrial does not merge the cases. Stare decisis, rather than law of the case, should be looked to when newcomers to the section 1407 transferee court seek to be heard on issues already considered in other cases in the pretrial consolidation group. ${ }^{408}$

As to Panel reconsideration of the rulings of transferee courts, the Panel has shown a very different attitude toward decisions of its selected section 1407 transferee judges than it has toward the decisions of transferor courts. Consistent with its philosophy of leaving as much as possible to the transferee judges once they have become involved, the Panel has been reluctant to alter decisions by the section 1407 judges on questions that have come before both section 1407 judges and the -Panel. Such questions include whether to add tag-along actions ${ }^{\mathbf{4 0 z}}$ and whether and when to remand particular civil actions to the courts in which they originated. The Panel places great weight on a transferee judge's "suggestion" that cases be remanded and imposes a strong bur-

106 Judge Harvey's conclusion was particularly striking because the Panel had stated in In re Plumbing Fixtures Litig., 342 F. Supp. 756, 757 (J.P.M.D.L. 1972), that Van Dusen v. Barrack, 376 U.S. 612 (1964), would apply to a transferred antitrust claim. Under the interpretation of federal law of the transferor court, the newly consolidated plaintiff might have had standing. Invoking law of the case, Judge Harvey held against their standing. As already noted, the decision against standing later was approved by the Supreme Court in Illinois Brick Co. v. Illnois, 431 U.S. 720 (1977).

For an additional case in which a $\S 1407$ transferee court adhered to its own prior ruling, see Tennessee Valley Auth. v. Westinghouse Elec. Corp., 429 F. Supp. 940, 944 (E.D. Va. 1977) (refusing to modify a portion of an order establishing a schedule for the delivery of uranium to various utility companies, pending resolution of multidistrict breach of contract actions in which defendant sought to be partially excused from performing on grounds of commercial impracticability). The original order in that case was "the product of delicate negotiations by the parties." The court also refused to vacate an order granting Westinghouse leave to file an amended answer. Id.

${ }^{607}$ See, e.g., In re Cessna Aircraft Distributorship Antitrust Litig., 460 F. Supp. 159, 162 (J.P.M.D.L. 1978) (refusing to transfer actions raising claims that $\S 1407$ transferee judge had refused to allow to come into the consolidated actions by way of cross claims). 
den of persuasion on any party seeking remand of an action who has not obtained a remand recommendation from the transferee judge. ${ }^{\mathbf{4 0 8}}$ The Panel is not acting on law of the case doctrine, however, for the actual decision on remand belongs solely to the Panel; the transferee judge can advise the Panel, but she cannot decide the issue. ${ }^{408}$

\section{Reconsideration in the Remand Court}

Many cases terminate in the hands of the section 1407 transferee courts. ${ }^{110}$ Nevertheless, although the percentage of transferred cases remanded back to the transferor courts is a relatively low twenty-two percent, a sizeable number of cases is involved. As of June 30,1985, approximately 2740 cases had been so remanded. ${ }^{411}$ Remand courts should take care to utilize law of the case doctrine only when the ruling in question was made in the very case before the remand court, not exclusively in other components of the multidistrict litigation. If the ruling was entered in other cases that have not yet gone to judgment, it is of only persuasive value. If entered in any of the multidistrict cases that have gone to judgment, the ruling may be respected as a matter of stare decisis. In either of these situations, the parties have a right to be heard, even though the court may be disposed to rule consistently with the rulings in the past companion cases. Under appropriate circumstances, collateral estoppel could apply. ${ }^{412}$

408 See In re Richardson-Merrell, Inc. "Bendectin" Prods. Liab. Litig. (No. II), 606 F. Supp. 715, 716 (J.P.M.D.L. 1985) (action remanded because of deference accorded judge's suggestion that remand was appropriate; remand would not be appropriate absent the judge's recommendation); In re Data Gen. Corp. Antitrust Litig., $510 \mathrm{~F}$. Supp. 1220, 1226 (J.P.M.D.L. 1979) ("Absent a notice of suggestion of remand from the transferee judge to the Panel, any party advocating remand . . . bears a strong burden of persuasion."); In re Air Crash Disaster Near Chicago, 476 F. Supp. 445, 450 n.6 (J.P.M.D.L. 1979).

409 See 28 U.S.C. § 1407(e) (1982); FED. R. P. OF THE J.P.M.D.L. 11 (1985); In re "East of the Rockies" Concrete Pipe Antitrust Cases, 302 F. Supp. 244, 254 n.1 (J.P.M.D.L. 1969) ("Only the Panel has the power to order a remand.") (Weigel, J., concurring).

410 Of the 12,484 actions terminated by transferee courts or remanded by the J.P.M.D.L. from 1968 through 1985, 2582 were remanded and 159 were reassigned to transferor judges within the transferee district. Consequently, 9743 actions terminated in $\S 1407$ transferee courts. See 1985 U.S. CTS. ANN. REP., supra note 6, at 168.

\&11 Of the total 12,484 actions subjected to $\S 1407$ proceedings from 1968-1985 but not presently pending and subject thereto, the sum of those that have been remanded by the Panel (2582) and those that have been reassigned to transferor judges within the transferee district (159) equals 2741 . This is $22 \%$ of the total 12,484 . See 1985 U.S. Cirs. ANN. REP., supra note 6, at 168.

${ }_{112}$ See Humphreys v. Tann, 487 F.2d 666, 671 (6th Cir. 1973) (plaintiffs in multidistrict litigation could not be collaterally estopped from proving defendant's negligence by virtue of a decision in defendant's favor in a case arising out of the same occurrence, but brought by other plaintiffs and not part of the consolidation nor made a 
For the reasons set forth earlier, a remand court will not have grounds to refuse to respect rulings of the section 1407 court on the grounds that the latter lacked subject matter jurisdiction over the case. ${ }^{413}$ Similarly, it cannot ignore rulings of the section 1407 court on the grounds that the 1407 court lacked personal jurisdiction over the parties or was not a proper venue. ${ }^{\mathbf{4 1 4}}$ If differences exist between the law of the case doctrine as applied by the section 1407 court and by the remand court, the remand court must consider whose doctrine applies. In cases and as to issues where the section 1407 transferee court sought to conduct itself as the transferor court would, ${ }^{\mathbf{4 1 5}}$ the transferor and remand court should use its own doctrine, whether law of the case is regarded as substantive or procedural. It makes no sense in this context to apply Van Dusen ${ }^{416}$ so as to treat the section 1407 court as a transferor court whose own law is to be applied in the remand court, viewed

test case by agreement of the parties), cert. denied, 416 U.S. 956 (1974); In re Nissan Motor Corp. Antitrust Litig., 471 F. Supp. 754, 758-60 (S.D. Fla. 1979) (remaining plaintiffs in multidistrict litigation would not be collaterally estopped by findings adverse to plaintiffs in another of the consolidated cases; the court rejected the argument that a likeness in complaint, closely coordinated pretrial responsibilities and joint motions and strategies justified collateral estoppel); see also In re Yarn Processing Patent Validity Litig., 472 F. Supp. 174, 177 (S.D. Fla. 1979) ( $\$ 1407$ transferee court could prohibit defendants in multidistrict litigation from asserting collateral estoppel upon remand to transferor court, to avoid allowing them to reap the benefit of a favorable determination in the trial against other defendants while escaping the binding effect of an unfavorable determination). The Yarn Processing case is defended in Statman, The Defensive Use of Collateral Estoppel in Multidistrict Litigation after Parklane, 83 Dick. L. Rev. 469, 484-85 \& nn.100 \& 103 (1979); its potential for abuse is noted in 15 WRIGHT \& MilleR, supra note $7, \S 3866$, at 623 ("A transferee judge could use the threat of precluding the defense of collateral estoppel as a way of exerting undue pressure to obtain consent of the parties to waive venue, which means that the limitations of Section 1404(a) could be routinely circumvented."); Sentner v. Amtrak, 540 F. Supp. 557, 558 n.3 (D.N.J. 1982) (the $\S 1407$ court concluded that, as to plaintiffs not parties to its instant interlocutory ruling but in the $\$ 1407$ litigation, the common government defendant would be collaterally estopped from relitigating the identical issue upon remand to transferor courts).

418 See supra text accompanying notes 391-95.

614 If orders entered by the remand court prior to transfer were raised for reconsideration, the court would use its own law of the case doctrine, of course. No problem should arise of the remand court being unable properly to apply its own law because it is an improper venue or cannot assert personal jurisdiction over the parties. By the time of remand any objections to venue and to personal jurisdiction will have to have been raised and determined. If the transferor court was not a proper venue or lacked personal jurisdiction but no objection was made, such objections were waived. See FED. R. Crv. P. 12(h)(1). If objections were timely made and sustained, the case would not have been remanded, but instead would have been transferred, under 28 U.S.C. $\S 1404$ or $\S 1406$, to a district of proper venue and able to assert personal jurisdiction over the defendants. Of course, the objection of lack of subject matter jurisdiction is never waived. See Fed. R. Giv. P. 12(h)(3).

41s See supra text accompanying notes 245.

«16 Van Dusen v. Barrack, 376 U.S. 612 (1964). 
as transferee court. To do so would defeat Van Dusen's very purpose of seeking to ensure that a change of courthouse will not change governing law. By contrast, in cases and as to issues where the section 1407 transferee court decided issues pursuant to the law as understood and interpreted by the section 1407 transferee court and its circuit, the remand court ought to apply the law of the case doctrine of the transferee court, whose ruling is in question. One of the advantages of this conclusion is that it minimizes the chances that the several remand courts in a given multidistrict case will reach different conclusions on the propriety of affording reconsideration of an issue.

- As to the ideal content of the law of the case doctrine to be applied, there is widespread recognition that remand courts generally must adhere to the rulings of section 1407 courts so as not to undermine those courts' efforts to afford uniform handling or to impair the efficiencies derived from such handling. ${ }^{417}$ Some years ago, Judge Stanley Weigel, then a member of the Panel, went so far as to opine:

Modifications or expansions to further the effectiveness of such orders [by a transferee judge] would appear to be proper - perhaps necessary in some instances. However, it would be improper to permit a transferor judge to overturn orders of a transferee judge even though error in the latter might result in reversal of the final judgment of the transferor court. If transferor judges were permitted to upset rulings of transferee judges, the result would be an undermin-

117 See, e.g., Sentner v. Amtrak, 540 F. Supp. 557, 558 n.3 (D.N.J. 1982). The $\S 1407$ court rejected Amtrak's argument that, as an instrumentality of the United States, as a matter of law it could not be held liable for punitive damages. It therefore granted plaintiffs leave to amend their complaint to seek recovery of punitive damages. The court then noted its expectations of the effect of its ruling in remand courts:

With regard to the instant case, this opinion constitutes the law of the case and should be adhered to upon remand, absent any unusual circumstances which would require reconsideration, such as appellate formulation or legislative creation of a supervening rule of law.

The important point for MDL transferor courts to note when considering this ruling upon remand is that this Court has devoted such thorough and careful consideration to plaintiff's motion under Fed. R. Civ. P. 15 as would be afforded a motion under Fed. R. Civ. P. 12(c) or for summary judgment by defendant on the issue presented.

Id.; see also Allegheny Airlines, Inc. v. LeMay, 448 F.2d 1341, 1345 (7th Cir.) ("The transferor court when the case is returned to it is . . . in the position of a third court on a second change of venue and takes the case with all of its errors, if any . . . ."), cert. denied, 404 U.S. 1001 (1971); cf. In re Multi-Piece Rim Prods. Liab. Litig., 653 F.2d 671, 678 (D.C. Cir. 1981) (stating, in an appeal from a discovery district court's denial of a motion to compel discovery, "[P]roper coordination of complex litigation may be frustrated if other courts do not follow the lead of the transferee court."). 
ing of the purpose and usefulness of transfer under Section 1407 for coordinated or consolidated pretrial proceedings because those proceedings would then lack the finality (at the trial court level) requisite to the convenience of witnesses and parties and to efficient conduct of actions. ${ }^{418}$

In particular, transferor judges who have had rulings altered by the section 1407 court must take care not to return the favor, absent principled grounds. Otherwise, in addition to other adverse consequences, concern on the part of the section 1407 transferee judges about whether remand courts will act appropriately may affect their decisions whether to recommend remand. ${ }^{419}$ In contrast, a remand court asked to reconsider the ruling of a "mere" discovery court may not need to be quite so deferential. Nonetheless, such a court, as well as a remand court asked to reconsider a pre-transfer ruling of its own, always should carefully consider whether adherence to, or departure from, the earlier ruling would undermine the uniformity of treatment or efficiencies afforded through the multidistrict handling.

It is possible, of course, that the applicable body of law will point toward allowing reconsideration. In contrast with Judge Weigel, this Article suggests that when the recognized exceptions to law of the case doctrine normally would apply, the reasons for affording reconsideration may well outweigh the policies supporting uniformity among the remanded and further transferred multidistrict cases. Each remand court will need to balance the competing considerations. In general, remand courts seem to adhere to section 1407 court rulings as law of the case, and to depart from such rulings only under standard exceptions. An example is In re Ohio River Disaster Litigation. ${ }^{420}$ The district court there held that, because of an intervening appellate decision, it was not bound by a prior determination made by another member of the same court acting as the section 1407 judge, denying the government's motion to dismiss claims arising from the freezing of the Ohio River. An intervening decision by the Court of Appeals for the Sixth Circuit, holding that the discretionary function exemption of the Fed-

11 Weigel, The Judicial Panel on Multidistrict Litigation, Transferor Courts and Transferee Courts, 78 F.R.D. 575, 577 (1978).

419 See Zinser v. Continental Grain Co., 660 F.2d 754 (10th Cir. 1981), cert. denied, 455 U.S. 941 (1982). The appellate court here stated that the trial court did not err in refusing to remand certain cases: "[T] his request was made only after the handwriting was on the wall." Id. at 762 . The $\$ 1407$ court had held plaintiffs precluded from suing under the rule in Illinois Brick Co. v. Illinois, 431 U.S. 720 (1977), and this cryptic remark may have reflected a perception that plaintiffs sought remand in hopes of getting a more favorable ruling.

120579 F. Supp. 1273 (S.D. Ohio 1984). 
eral Tort Glaims Act should be read into the Suits in Admiralty Act, ${ }^{\mathbf{4 2 1}}$ required the district court to determine whether the government was immune from any of the claims asserted against it. ${ }^{\mathbf{2 2}}$

The Ohio River case suggests the question whether the intervening Sixth Circuit decision would have justified reconsideration of the government's motion to dismiss if the section 1407 court had been outside the Sixth Circuit and the remand court within the Sixth Circuit. The answer turns in large part upon whether the remand court would regard Sixth Circuit law as governing. If it would, the law of the case exceptions for clearly erroneous decisions and intervening changes in the law would be applicable. Although a narrow reading of section $1294^{\mathbf{4 2 3}}$ indicates that the Sixth Circuit is without jurisdiction to review the section 1407 court's ruling, ${ }^{424}$ there is dictum expressing the viewpoint that section 1407 court rulings return to the transferor court upon remand and are reviewable on appeal to the court of appeals for the remand court. ${ }^{428}$ In either event, the law of the case consequences should be as just described. ${ }^{426}$

\section{Reconsideration in the Ultimate Transferee Court}

After a case has been sent to a section 1407 transferee court, that court may transfer the case for all purposes either to itself or to a third court under the applicable section (1404 or 1406), ${ }^{427}$ rather than recommend remand to the transferor court. In either event, the ultimate transferee court could be asked to reconsider rulings made by the original transferor court, by the section 1407 court, sitting as such, or by a discovery court. In determining whether the challenged rulings should be accorded respect, it is appropriate for the ultimate transferee court to consider whether the court whose ruling is challenged had subject mat-

42146 U.S.C. $\$ \S 741-752$ (1982). The Federal Tort Claims Act, Pub. L. No. 79753,60 Stat. 842 , is codified as amended in scattered sections of Title 28 (28 U.S.C. $\S \S 1346(b), 2671-2680$ (a) (1982 \& Supp. III 1985)).

422 Ohio River Disaster, 579 F. Supp. at 1279.

42828 U.S.C. § 1294 (1982).

424 See supra text accompanying note 160 .

128 Allegheny Airlines, Inc. v. LeMay, 448 F.2d 1341, 1344-45 (7th Cir.) (appellate court for $\S 1407$ transferee district held that $\S 1407$ court orders dismissing thirdparty complaints without prejudice were neither final judgments nor within any exception to 28 U.S.C. § 1291; it opined that the question of the error, if any, in the dismissal of the third-party complaints would be subject to review at the time of entry of judgment in the ultimate trial forum), cert. denied, 404 U.S. 1001 (1971); see also 15 WRIGHT \& MILlER, supra note 7, § 3862, at 509 ("Of course, once a case has been remanded . . . and a final judgment has been entered, any appeal may include objections to errors allegedly committed by the transferee judge").

${ }^{428}$ See supra text accompanying notes 417-23.

42728 U.S.C. $\S \S 1404,1406$ (1982). 
ter and personal jurisdiction and was a proper venue. The consequences of the presence or absence of each of these matters already have been elaborated. ${ }^{\mathbf{4 2}}$

As is true for other participating courts, the ultimate transferee court should invoke law of the case doctrine only when the ruling in question was made in the very case now before it. A critical prerequisite of the doctrine is not met if the ruling was made exclusively in other components of the section 1407 litigation. Nonetheless, the policy of maintaining equality of treatment with those past companion cases should lead to careful consideration of the rulings made in those cases. As to choice of law, the ultimate transferee court ordinarily should apply the law of the case doctrine that would be used by the court whose ruling has been challenged. If the court is faced with challenges of rulings from a large number of transferor or discovery courts, it can, in the exercise of sound discretion, choose to use one of their doctrines or its own doctrine, if the inefficiencies and inequities of acting otherwise so indicate.

In applying the applicable law of the case doctrine, the ultimate transferee court should consider the applicability of the exceptions recognized and the special factors involved by dint of the case coming from multidistrict coordination or consolidation for pretrial. It should also consider the unavailability of the judge who initially ruled, unless the section 1407 judge has kept the case and reconsideration of her ruling is sought. It should take into account the extent to which reconsideration would undermine the uniformity of treatment and the efficiencies sought to be afforded through the multidistrict handling. In this regard, it will be relevant whether other remand courts or ultimate transferee courts already have reconsidered or agreed to reconsider the same or other rulings in the section 1407 cases.

With respect to the typical exceptions to law of the case doctrine, the questions again arise whether and when those for clearly erroneous rulings and intervening changes in law properly can be invoked. It is this Article's position that whether or not the ruling courts' rulings are reviewable on appeal to the court of appeals for the ultimate transferee court, the law of the case exceptions for clearly erroneous decisions and intervening changes in law suitably can be invoked, with general choice of law principles determining which circuit's law is pertinent for determining error. ${ }^{428}$

128 See supra text accompanying notes 189-201.

420 When the $\S 1407$ court also is the ultimate transferee court it will be clear that appeals from its decisions are to be made in the circuit where the court sits. See In re Exterior Siding \& Aluminum Coil Litig., 538 F. Supp. 45, 48 (D. Minn. 1982), supra 


\section{CoNCLUSION}

Multidistrict consolidation for pretrial proceedings has become an essential tool in the federal courts' arsenal for handling complex litigation, but it has created new procedural quandaries. The novel twists that multidistrict litigation gives to old problems and the new questions it raises must be thoughtfully considered and resolved to allow the multidistrict mechanism to fulfill its purpose of fostering the efficient administration of justice, and in particular, of eliminating the potential for conflicting rulings by coordinate district and appellate courts presiding over related civil actions. This Article has focused on one uncertainty: how law of the case doctrine should be adapted to fit multidistrict litigation. It has attempted to formulate a set of answers by separating multidistrict litigation into its various components that complicate the use of law of the case doctrine, by analyzing what adjustments they require, and then by newly synthesizing the doctrine to accommodate the peculiarities and fit the needs of multidistrict litigation. The problems are admittedly difficult. The courts can continue to make valuable contributions to the field through analyses of the problems presented which are systematic and thorough and at the same time sensitive to the policies that underlie section 1407, law of the case, and the exceptions to that doctrine.

text accompanying notes $280-312$. Otherwise, if or when the ruling court's rulings are not reviewable on appeal to the court of appeals for the ultimate transferee court, the rulings never could be tested against the pertinent law by the ultimate transferee court or its court of appeals. Only an interlocutory appeal in the ruling court's court of appeals could change the law of the case.

Examples of ultimate transferee courts faced with law of the case arguments are: Greyhound Computer Corp., Inc. v. IBM Corp., 559 F.2d 488, 507-08 (9th Cir. 1977) (where plaintiff had demonstrated no prejudice, trial court did not abuse its discretion in permitting IBM to raise hearsay objection at trial, despite IBM's failure to object to admissibility by date set by $\S 1407$ transferee judge), cert. denied, 434 U.S. 1040 (1978); Bishop v. Firestone Tire \& Rubber Co., 579 F. Supp. 397, 401 (N.D. Ind. 1983) (ruling by $\S 1407$ transferee court striking plaintiff's conspiracy allegations were law of the case; ultimate transferee court had not been asked to disturb the ruling and commented that there was no reason apparent in the record to do so). 